\title{
Trinta anos do bicudo-do-algodoeiro no Brasil
}

\author{
Thirty years of cotton boll weevil in Brazil
}

Rosalia Azambuja1*, Paulo Eduardo Degrande1

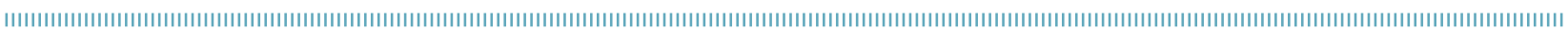

RESUMO: Este texto é uma revisão bibliográfica que abrange 30 anos de ocorrência do bicudo-do-algodoeiro, Anthonomus grandis Boheman, 1843 (Coleoptera: Curculionidae), no Brasil. O bicudo é considerado uma das pragas mais prejudiciais à agricultura pelos danos que causa e pelas dificuldades de seu controle. Originário do México, esse inseto foi constatado pela primeira vez no Brasil em 1983 e duas safras após seu surgimento já estava disseminado nas principais áreas produtoras de algodão no país, onde se mantém até a atualidade. Quando náo controlado, esse inseto pode destruir completamente a produção de um algodoal, já quando controlado os prejuízos variam de 3 a $75 \%$ da produtividade esperada. Os principais danos causados pelo bicudo são resultantes de orifícios promovidos nas estruturas reprodutivas da planta durante a alimentação e oviposiçáo dos adultos, sendo os botóes florais as estruturas preferencialmente atacadas pelo inseto. $\mathrm{O}$ período de ataque do bicudo às plantas de algodoeiro se inicia por volta dos 30 dias após a emergência, no estabelecimento vegetativo da cultura, passando pelo florescimento e frutificaçáo e chegando até a fase de maturaçáo, sendo que durante esse período vários métodos podem ser adotados visando ao seu controle. Para controle de $A$. grandis, no Brasil, são citados métodos de controle comportamental, controle cultural, resistência de plantas, controle biológico (predadores, parasitoides e patógenos), produtos naturais, controle legislativo e manejo integrado, além de iniciativas de programas de supressão populacional do inseto. $\mathrm{O}$ controle químico não é discutido neste artigo.

PALAVRAS-CHAVE: Anthonomus grandis; Gossypium hirsutum; danos; ocorrência; controle.

\begin{abstract}
This paper is a literature review that covers 30 years of occurrence of the boll weevil, Anthonomus grandis Boheman, 1843 (Coleoptera: Curculionidae), in Brazil. The boll weevil is considered one of the most destructive pests in the agricultural system; the damage that it causes and the difficulties of its control in cotton is enormous. Originally from Mexico, this insect was first found in Brazil in 1983 and two seasons after the detection it was widespread in major cotton producing areas where it remains until today. When boll weevil is not controlled, it can completely destroy the economic cotton production; the losses range can vary from 3 to $75 \%$ of the expected productivity. The main damage caused by the boll weevil in cotton is promoted in the reproductive structures of the plant during feeding and oviposition of adult insects; the flower buds are preferentially attacked by the insect. The period of the weevil attack on cotton plants begins around 30 days after emergence, but it starts at the vegetative period; damage occurs at the flowering and fruiting period and reaches the maturation phase. During these periods several methods can be adopted aiming its control. To control A. grandis in Brazil the following methods are cited: behavioral control, cultural control, host plant resistance, biological control (predators, parasitoids, and pathogens), natural products, legislative control and integrated pest management, and program initiatives for suppression of the insect population. Chemical control is not discussed in this article.
\end{abstract}

KEYWORDS: Anthonomus grandis; Gossypium hirsutum; damage; occurrence; control. 


\section{INTRODUÇÃO}

Este texto é uma revisão bibliográfica que abrange 30 anos de ocorrência do bicudo-do-algodoeiro, Anthonomus grandis Boheman, 1843 (Coleoptera: Curculionidae), no Brasil, com ênfase em informaçóes de bibliografia publicada em território nacional e versa sobre detecção regional, fisiologia, ecologia, etologia, distribuição geográfica (mapeamento), plantas hospedeiras, dinâmica populacional, prejuízo e dano econômico, amostragem, nível de controle, controle comportamental, cultural e alternativo aos inseticidas químicos, resistência de planta, controle biológico e microbiano, prospecção de produtos naturais, controle legislativo, iniciativas de planos de supressão, e adequaçáo ao manejo integrado de pragas (MIP).

\section{ANTECEDENTES GERAIS}

O bicudo-do-algodoeiro é considerado uma das pragas mais prejudiciais à agricultura pelos danos que causa e pelas dificuldades de seu controle (Broglio-Micheletti, 1991; Degrande et al., 2002; Gabriel; Blanco, 2009). Esse inseto foi descrito por C. H. Boheman em 1843 como Anthonomus grandis a partir de um adulto coletado entre 1831 e 1835 e denominado "Veracruz", sem hospedeiro registrado (BAstos et al., 2005). Ele é citado como originário das terras baixas do México (Nakano et al., 1987; Confalonieri et al., 2000), de onde se distribuiu para a regiáo Sul e Norte dos Estados Unidos. De acordo com TomQuelski; Martins (2008), o bicudo invadiu o Texas, Estados Unidos, em 1892; em 1949, foi encontrado na Venezuela e, em 1950, na Colômbia. No Brasil foi constado pela primeira vez em 1983 (Habib; Fernandes, 1983). Posteriormente, em 1991, o bicudo-do-algodoeiro entrou no Paraguai a partir do Brasil e rapidamente se estabeleceu em $90 \%$ das zonas de produçáo (MANessi, 2000). Na Argentina foi detectado pela primeira vez em 1993 (Barbosa, 1997).

\section{HISTÓRICO NO BRASIL}

O bicudo-do-algodoeiro é uma praga introduzida no Brasil, que em 30 anos se disseminou com sucesso para várias regiôes se tornando a principal praga do algodoeiro no país (Paula et al., 2013).

A constataçáo do bicudo no Brasil ocorreu pela primeira vez em fevereiro de 1983, em cultivo de algodoeiro próximo ao aeroporto de Viracopos (Degrande et al., 2004; Busoli; Michelotto, 2005), na região de Campinas, São Paulo. Nessa regiáo o inseto foi encontrado em grandes densidades populacionais, causou injúrias em botóes florais e atingiu níveis de aproximadamente $90 \%$ de infestação (Habib; Fernandes, 1983). De acordo com resultados de Confalonieri et al. (2000), obtidos a partir de um estudo de filo geográfico, o bicudo-do-algodoeiro do Brasil e do Paraguai foi introduzido a partir de insetos oriundos dos Estados Unidos. Da regiáo de Campinas, então, esse inseto foi se alastrando pelas principais áreas produtoras de algodáo (Jaramillo; Alves, 1986). Nesse mesmo ano foi registrada a ocorrência desse inseto em 46 municípios do estado de São Paulo (Belorte; Ramiro, 1993). Paralelamente, na regiáo Nordeste do Brasil, o bicudo-do-algodoeiro foi constatado pela primeira vez em julho de 1983 (Braga Sobrinho; Lukefahr, 1984a), na regiāo de Campina Grande e Ingá no estado da Paraíba (Degrande et al., 2004; Silva, 2012). Nessa regiáo, $A$. grandis foi apontado como praga-chave do algodoeiro, pois as favoráveis condiçôes climáticas e ecológicas da região permitiram sua rápida sobrevivência, multiplicação, adaptação, dispersão e migração em diversos ambientes (Braga Sobrinho et al., 1991). Essas ocorrências simultâneas em áreas extensas e com populaçóes elevadas sugerem que a praga entrou no Brasil nessas duas regióes, distantes entre si, a partir de duas introduçóes (Degrande et al., 2004; Degrande, 2006). Santos et al. (1989) relataram $A$. grandis como um dos insetos praga associados ao algodoeiro no estado do Paraná. Nesse estado o inseto foi relatado pela primeira vez, no ano 1984 , nos municípios de Barra do Jacaré e Maringá (SiLVA, 2012).

Segundo Campanhola et al. (1988a), na safra 1983/1984, após a entrada do bicudo no Brasil, houve um decréscimo de 19,9 e 32,9\%, respectivamente, da área plantada com algodáo na regiáo de Campinas e Sorocaba em relaçáo à safra anterior. As propriedades com maiores danos de bicudo apresentaram, de imediato, decréscimos na produtividade de 4,7 e 6,6\%, em Campinas e Sorocaba, respectivamente, sendo que nessa mesma safra o bicudo (recém-introduzido no Brasil) foi mais prejudicial do que a lagarta-rosada, praga de expressão na região naquela época. De acordo com Santos (2004), duas safras após o surgimento do bicudo, no Brasil, esse inseto já estava disseminado nas principais áreas produtoras de algodáo no país, onde se mantém até a atualidade (Tomquelski; Martins, 2008; Silva, 2012). Degrande et al. (2004) e Degrande (2006) relataram que o bicudo deveria ter sido erradicado quando chegou ao Brasil, mas nenhuma atitude prática funcional foi tomada na época para que isso ocorresse, embora a Secretaria da Agricultura e Abastecimento do Estado de Sáo Paulo, por meio do Instituto Biológico, do Instituto Agronômico de Campinas e da Defesa Sanitária Vegetal, tivesse elaborado, em junho de 1983, um plano de combate ao A. grandis. Assim, por anos a alternativa utilizada pelos produtores foi conviver com a praga e com os problemas trazidos por ela, adotando um nível de controle de $10 \%$ dos botóes florais atacados. 
Segundo Bastos; Almeida (2005), a partir da ampla disseminação do bicudo no Brasil, em 1985 houve um decréscimo na área colhida de algodáo arbóreo, caindo 48\% em relaçấo à mesma área colhida no período compreendido entre 1976 e 1977. Santos (2004) relatou que o surgimento do bicudo, no Brasil, aliado ao baixo preço da fibra na safra 1996/1997, contribuiu para o registro de uma das menores produçôes de plumas na história do país (285.000 t); outros problemas contribuíram para a decadência da atividade na época, como elevação dos custos de controle, falta de crédito para os produtores, sistemas insustentáveis de arrendamento de terras, impacto na importaçấo desenfreada da fibra, desestruturação da extensão rural, desorganização da cadeia produtiva e falta de uma política agrícola para a atividade (Degrande et al., 2004).

Segundo Degrande et al. (2004) e Degrande (2006), o algodáo brasileiro voltou a ter destaque no mercado interno $\mathrm{e}$ externo a partir de 1996, quando os algodoais se expandiram para o Cerrado brasileiro e o algodáo começou a ser cultivado em áreas de baixa prevalência ou ainda não infestadas pelo bicudo, com clima favorável e produtores dispostos a trabalhar num novo patamar tecnológico e de investimentos.

\section{DISTRIBUIÇÃO GEOGRÁFICA}

O bicudo-do-algodoeiro apresenta ampla distribuição geográfica no Brasil. A bibliografia nacional apresenta relatos em cidades nos estados da Bahia (Brugnera, 2009; Silva, 2012), Ceará (Braga Sobrinho et al., 1991; Vieira et al., 1991a; Bleicher et al., 1994; Azevedo; Vieira, 2002; Silva et al., 2008), Distrito Federal (Ribeiro et al., 2005a; Bravo et al., 2010), Goiás (Degrande et al., 2004; Tomquelski; Martins, 2008; Bravo et al., 2010; Silva, 2012), Mato Grosso (Scomparin et al., 2005a, 2005b; TomQuelski; Martins, 2008; Silva, 2012), Mato Grosso do Sul (Degrande et al., 2002; TomQuelski; Martins, 2008), Paraná (Morales et al., 1997; Silva, 2011), Paraíba (Braga Sobrinho et al., 1991; Silva, 2011), Pernambuco (Ramalho et al., 1990; Bleicher; Almeida, 1991; Braga Sobrinho et al., 1991; BroglioMicheletti, 1991; Almeida et al., 1997; Ramalho et al., 1998; Coutinho; Cavalcanti, 1988; Lemos et al., 1999; Degrande et al., 2004), Rio Grande do Norte (Braga Sobrinho et al., 1991), São Paulo (Andrade et al., 1984; Pierozzi Jr. et al., 1984; Gabriel, 1984a, 1984b; Campanhola et al., 1984; Habib; Pierozzi JR., 1986; Pierozzi Jr.; Habib, 1986; Campanhola et al., 1988a, 1988b; Ramiro et al., 1989; Braga Sobrinho et al., 1991; CAstro et al., 1991; Santos et al., 1991; Busoli et al., 1991; Gabriel et al., 1992; Paron et al., 1993a; Soares; Yamamoto, 1993a, 1993b; Soares; Lara, 1993a; Volpe et al., 1993; Belorte; Ramiro, 1993; Gabriel; Muniz, 1993; Gabriel, 1995; Paron et al., 1995; Degrande et al., 2004).

\section{CARACTERÍSTICAS GERAIS}

$\mathrm{O}$ adulto do bicudo-do-algodoeiro é um besouro que mede de 4 a $9 \mathrm{~mm}$ de comprimento e $7 \mathrm{~mm}$ de envergadura, tem coloraçáo que varia de pardo-acinzentado ao preto, com pelos dourados esparsos sobre os dois élitros, onde se observam estrias ou sulcos longitudinais (Gravena, 2001; Busoli; Michelotto, 2005; Tomquelski; Martins, 2008; Silva, 2012). Para Tomquelski; Martins (2008), a coloração varia conforme a idade e alimentaçâo do inseto; o inseto possui um rostro (bico alongado) escuro, medindo cerca de metade do tamanho do resto do seu corpo, no qual na extremidade apical se encontram as peças bucais, e mais ou menos no centro do rostro situam-se as antenas (Gravena, 2001; Busoli; Michelotto, 2005; TomQuelski; Martins, 2008; SiLVA, 2012).

Vêloso (1987), TomQuelski; Martins (2008) relataram que $A$ grandis possui, nos fêmures anteriores, um espinho grande dividido, sendo um acuminado e outro rombudo, por uma bifurcaçấo, característica que o diferencia dos outros curculionídeos. De acordo com Gravena (2001), o bicudo é um inseto lento ao caminhar, que raramente voa, a não ser quando se dirige para a hibernaçáo.

Segundo Claudino et al. (2010a), fêmeas dormentes apresentam ausência de ovos e os machos têm atrofia testicular e vesicular, enquanto que fêmeas reprodutivas, independentemente da idade, apresentam ovários com ovos vitelados (3 a 5) e machos reprodutivos têm vesícula seminal estendida e ausência de atrofia testicular. Os ovos do bicudo sáo elípticos, de coloração branca brilhante e medem cerca de $0,8 \mathrm{~mm}$ de comprimento por $0,5 \mathrm{~mm}$ de largura (GravenA, 2001; Tomquelski; Martins, 2008). As larvas são brancas, ápodas, possuem cabeça marrom-clara e permanecem encurvadas dentro dos botóes florais, quando desenvolvidas apresentam entre 5 e $7 \mathrm{~mm}$ de comprimento (Santos, 2002; TomQuelsKi; MarTins, 2008). As pupas são brancas, podendo-se observar vestígios dos diferentes membros do corpo do futuro adulto, como os olhos e o rostro (Santos, 2002; TomQuelski; Martins, 2008).

\section{FISIOLOGIA}

A diapausa manifestada nos adultos de $A$. grandis é um dos mecanismos utilizados pelo inseto para sua sobrevivência no período de entressafra. No estado de Sáo Paulo, 
CAMPANHola et al. (1984) observaram que adultos do bicudo-do-algodoeiro começam a sair da diapausa e dos locais de abrigo entre o final de setembro e o início de outubro. Nesse período o número de insetos coletados foi considerável, chegando a 55,5 insetos/dia por armadilha em um período de 15 dias, após, o número de insetos foi diminuindo até se tornar mínimo no final de janeiro, indicando ser esse o período limite de saída dos insetos que estavam em diapausa.

Braga Sobrinho; Lukefahr (1984a) coletaram botôes florais e maçãs atacadas pelo bicudo-do-algodoeiro para verificar a ocorrência e o grau de incidência de diapausa no inseto. Os resultados mostraram que no início de agosto ocorreu uma baixa incidência de indivíduos em diapausa, em segui$\mathrm{da}$, a porcentagem de indivíduos em diapausa foi aumentando gradativamente. No final de outubro, a porcentagem de insetos em diapausa ultrapassou $55 \%$ dos indivíduos, sendo a mais alta incidência de diapausa constada em insetos que emergiram de maçâs de algodoeiro.

Claudino et al. (2010b) sugeriram que o tipo de alimento associado ao estágio do desenvolvimento do bicudo são fatores relevantes na incidência de dormência reprodutiva e, consequentemente, em moldar a adaptabilidade do inseto à fenologia da cultura e ao período da entressafra. Bicudos que se alimentaram na fase larval de botôes florais apresentaram menor proporção de dormência (27, 47 e 57\% quando alimentados na fase adulta, respectivamente, de botão, maçã e pólen alternativo) do que aqueles que se alimentaram de maçã $(56,89$ e 58\% alimentados na fase adulta, respectivamente, de botấ, maçã e pólen alternativo), sendo a dormência predominante em fêmeas. Paula et al. (2013) afirmaram que a fonte de alimento aliada às condiçóes do campo durante o desenvolvimento dos adultos sáo fatores decisivos para a induçáo de dormência reprodutiva na regiáo Centro-Oeste do Brasil. Esses autores relataram que a incidência de dormência reprodutiva aumentou progressivamente com o desenvolvimento da fenologia da planta de algodáo, atingindo cerca de $90 \%$ no final do período de colheita.

De acordo com Claudino et al. (2010a), os bicudos do Cerrado são passíveis de entrar em dormência reprodutiva na fase adulta e permanecer assim por pelo menos 77 dias, havendo resposta diferencial em função do sexo. Esses autores observaram um atraso na resposta de dormência nos machos, ocorrendo a partir do vigésimo primeiro dia, já em fêmeas observou-se desde o sétimo dia, sendo a proporçáo de dormência macho:fêmea de 1,27:1.

Ramalho; Jesus (1987b) afirmaram que no agreste paraibano o bicudo-do-algodoeiro passa o período da entressafra fisiologicamente ativo, sendo que as fêmeas coletadas nesse período estavam sexualmente ativas, ocorrendo cópula, armazenamento de espermas e oviposição. Gabriel; TANCINI (1989) e Gabriel et al.(1991a), também realizando levantamentos quanto à hibernaçấo de adultos de $A$. grandis de junho a agosto, náo encontraram insetos em diapausa em amostragens de cobertura de solo. PAron et al. (1993b, 1995) determinaram que o teor de lipídios em adultos de $A$. grandis coletados na entressafra e na safra na regiáo de Jaboticabal, São Paulo, foi semelhante e concluíram que a não incidência de altos teores de lipídios na entressafra pode ser um indício da não diapausa dos insetos na região estudada.

Bicudos emergidos de maçãs foram proporcionalmente maiores (Ramalho; Gonzaga, 1989a; Paron et al., 1993a) e tiveram maior índice de infestação do que os emergidos de botôes (Paron et al., 1993a). Segundo Claudino et al. (2010c), de maneira geral, não existem diferenças marcantes no perfil de emergência de ambas estruturas reprodutivas do algodoeiro, no entanto, segundo Ramalho; GonZaga (1989a), adultos emergidos de botôes (1 bicudo/botão) têm cerca de dois terços à metade do tamanho dos emergidos de maçẫs ( $2 \pm 1$ bicudos/maçã), sendo as fêmeas mais pesadas do que os machos.

Oliveira Neto et al. (2000) relataram que as proteases serina e cisteína são as enzimas responsáveis pelas atividades proteolíticas no intestino de larvas e adultos desses insetos, porém, ainda não há um detalhamento em relação às suas funçôes no comportamento e na fisiologia do inseto baseado em literatura brasileira.

\section{BIOLOGIA}

A fêmea do bicudo-do-algodoeiro deposita seus ovos principalmente nos botóes florais, flores e maçãs. Após a eclosão, as larvas permanecem dentro do botão, usando a estrutura como uma fonte de alimento e como um habitat de proteçáo até que o desenvolvimento seja concluído e o adulto possa emergir (Diss et al., 2004). O adulto do bicudo-do-algodoeiro move-se ativamente nas superfícies vegetais do algodoeiro, alimentando-se e realizando posturas nos botôes florais, flores e maçãs novas (RAmiro et al., 1997).

De acordo com Gravena (2001), a capacidade de oviposição da fêmea decai de geração para geração à medida que o algodoeiro avança pelas fases de germinação, florescimento, frutificação e maturação, a ponto de, no final da safra, na época da colheita, uma fêmea colocar apenas um ovo a cada dois dias. Conforme o autor, as fêmeas adultas, após emergirem, precisam se alimentar durante 5 a 6 dias antes de iniciar a postura, sendo que um casal no início do ciclo pode dar origem a 12 milhôes de descendentes no final da safra.

O ciclo biológico de $A$. grandis está diretamente relacionado com a temperatura. De acordo com Broglio-MicheletTI (1991), as duraçôes do período de incubação dos ovos e do período pupal diminuem com o aumento da temperatura, verificando-se menor viabilidade embrionária e pupal a $30^{\circ} \mathrm{C}$. Degrande et al. (1983), estudando o efeito da temperatura sobre a emergência do bicudo, observaram emergência de 100\% 
dos adultos quando as pupas foram submetidas à temperatura de 20,25 e $30^{\circ} \mathrm{C}$, todas as pupas submetidas a $40^{\circ} \mathrm{C}$ tornaram-se inviáveis, já as pupas submetidas a $4^{\circ} \mathrm{C}$ permaneceram 45 dias em hibernação e houve emergência de apenas $80 \%$ dos adultos após as pupas serem submetidos a $22^{\circ} \mathrm{C}$. Além da temperatura ideal, as chuvas favorecem a sobrevivência das larvas e pupas do bicudo em botóes caídos sobre o solo, pois a umidade preserva melhor essas estruturas vegetais (DEGRANDE, 2004a).

GABriel et al. (1986), em estudo de biologia do bicudo, determinaram as duraçóes médias do período de incubação dos ovos de 4,14 e 5,34 dias, período larval de 8,22 e 9,47 dias e período pupal de 5,40 e 6,04 dias, para a $1^{\text {a }}$ e $2^{\text {a }}$ geração, respectivamente. Gabriel; Dias Neto (1989) observaram que o ciclo biológico de $A$. grandis em campo durou 20,3 dias; posteriormente, GABRIEL et al. (1991b) encontraram uma média ovo-adulto de 24,35 dias.

De acordo com Gabriel; Muniz (1993) e Gabriel (1995), a variação de temperatura, até mesmo acima de $38^{\circ} \mathrm{C}$ na superfície do solo, não influenciou na mortalidade de imaturos em desenvolvimento nos botóes florais caídos no solo, sugerindo que esse parâmetro climático não interfere na sobrevivência da população de bicudos. VolPE et al. (1993) observaram que temperaturas entre 25 e $26,5^{\circ} \mathrm{C}$ associadas à alta umidade, resultaram em uma mortalidade de 52 a $74 \%$ dos indivíduos. Segundo os mesmos autores, o aumento da temperatura até $29^{\circ} \mathrm{C}$ e a baixa umidade causaram mortalidade dos indivíduos, que foi superior a $92 \%$, indicando que a elevação da temperatura associada à queda da umidade provocam incrementos superiores a 37\% na mortalidade.

Gabriel; Tancini (1986) observaram, em laboratório, que a duraçáo do período ovo-adulto do bicudo foi de 17,5 dias em média, a longevidade dos adultos de 100,5 dias e o número médio de ovos/fêmea/dia de 3,45. De um total de 673 ovos estudados, apenas 49\% completaram o ciclo ovo-adulto, sendo a porcentagem de ovos náo eclodidos de $1,19 \%$ e a porcentagem de mortalidade de larva e pupa, respectivamente, 47,99 e 1,78\%. GABRIEL et al. (1986) relataram um período médio de oviposição das fêmeas de 130,76 dias, sendo o número de ovos por fêmea 177,72, uma média de 1,30 ovos por dia. Nesse trabalho, a porcentagem de eclosão foi de 66,98\%. Segundo Nakano (2006), o número de ovos por fêmea pode chegar até 300 .

Em trabalhos de campo, Almeida et al. (1997) observaram que os adultos do bicudo emergiram de botóes após 18,2 dias, sendo a porcentagem de emergência de 76,6\%, enquanto que RamalHo et al. (1993a) obtiveram porcentagens de emergência entre 61,6 e 68,3\% e Ramalho; Silva (1993) observaram sobrevivência de 65\% dos adultos.

Em estudo realizado por Broglio-MicheletTI (1991), a razão sexual foi de 0,54 , as longevidades de machos e fêmeas foram respectivamente 44,9 e 45,57 dias. Quanto aos aspectos reprodutivos, a duração do período de pré-oviposição foi 5,17 dias e do período de oviposição 25 dias, com uma média de 3,21 ovos/dia, totalizando um número médio de 79 ovos/fêmea. O peso médio dos adultos de A. grandis foi 0,01 g e o comprimento de 7,6 mm (AlmeidA et al., 1997). Com relação ao peso dos adultos, segundo Busoli; Michelotto (2005) e Michelotтo et al. (2007), observou-se uma correlação positiva entre o diâmetro dos botôes florais que são ovipositados pelas fêmeas do bicudo e a massa corporal dos adultos emergidos desses botóes, ou seja, um maior diâmetro de botão implica num adulto de maior massa corporal. Por isso, a escolha da variedade implica no controle desses insetos, uma vez que as fêmeas procuram os botóes maiores para realizar a oviposição, pois esses oferecem alimento suficiente para o desenvolvimento das larvas (Busoli; Michelotto, 2005).

Em estudo realizado por Broglio-Micheletti (1991), os valores da temperatura base (TB) em ${ }^{\circ} \mathrm{C}$ e da constante térmica ( $\mathrm{K}$, em graus-dias) do bicudo-do-algodoeiro para os períodos de ovo, pupa e ovo-pupa foram, respectivamente, de 10,4 e 49,0; 10,8 e 93,8; 12,3 e 251,2. Nobre et al. (2000), criando A. grandis em dieta artificial (soja, sementes de trigo, glicose, semente de algodão, suplemento de minerais e vitaminas), observaram que a duração do período ovo-adulto foi de 20,47 dias; a longevidade foi de 80 dias para as fêmeas e 61,96 para os machos, a razáo sexual de 0,4313 e o número médio de ovos produzidos de 129,64.

De acordo com SAntos (2002) e Cunha et al. (2010), no período de entressafra das plantas do gênero Gossypium sp., os bicudos adultos reduzem seu metabolismo fisiológico e se alimentam esporadicamente do pólen de outras espécies de plantas. GaBriel et al. (1986) estudaram a longevidade de adultos do bicudo alimentados com botóes florais do algodoeiro, flores de hibisco e frutos de bananeira e observaram, respectivamente, longevidades médias de 97,66; 71,73; e 85,48 dias. Cunha et al. (2010) reportaram que adultos do bicudo alimentados com flores de crotalária apresentaram uma longevidade muito baixa (7,60 dias), sugerindo que o inseto não teve acesso ao pólen das flores e concluindo que essa planta náo seja adequada para uso como cultura-armadilha.

\section{ECOLOGIA}

Anthonomus grandis tende a ser encontrado em botóes florais situados na porção mediana do algodoeiro (VIEIRA et al., 1991b). De acordo com Ramalho; Jesus (1987a), a oviposição e alimentação desse curculionídeo ocorre preferencialmente em botóes florais de tamanho médio (entre 3 e $6 \mathrm{~mm}$ de diâmetro) localizados na metade superior das plantas. CASTro et al. (1991) afirmaram que a alimentação ocorre em toda a planta, com maiores porcentagens nos ramos do ponteiro (ramos de 1 a 10), já a postura dos ovos é realizada em função do tamanho da estrutura floral, independente da sua localização na planta. 
Busoli et al. (2004) relataram que o bicudo-do-algodoeiro tem preferência alimentar por maçâs mais novas (2 dias idade), havendo reduçáo significativa no número de orifícios quando comparadas com maçãs de 8 e 12 dias.

RAMiro et al. (1997) recomendaram que o período da tarde seja o período utilizado para aplicaçáo de produtos para o controle do bicudo, pois nesse período os insetos estáo mais expostos à aplicação. Segundo esses autores, durante o período da manhã os insetos estáo se alimentando ou realizando posturas, estando protegidos pelas brácteas e menos expostos.

De acordo com Ramalho; Silva (1993), a emergência dos adultos de $A$. grandis dos botóes florais caídos no solo ocorre entre as 6:00 e as 16:00 horas, com um pico significativo entre 7:00 e 10:00 horas, não ocorrendo emergência de adultos no período entre 16:00 e 6:00 horas, segundo esses autores.

O número de orifícios causados durante a alimentação e oviposição pelas fêmeas de $A$. grandis em botôes florais segue uma relação curvilínea com o aumento da temperatura e densidade de botôes florais disponíveis para o inseto (Ramalho et al., 1993b; Ramalho, 1995). Soares; Үамамото (1993a, 1993b) relataram que as fêmeas do bicudo náo discriminam botôes previamente ovipositados e que o aumento do nível de infestação resulta no aumento do número de orifícios de oviposição/botấo e na emergência de mais de um adulto/botâo. Em níveis de infestação entre 11 e $20 \%$, por exemplo, os botóes florais apresentaram até dois orifícios de oviposiçấo. Quando o nível aumenta para $60 \%$ ou mais, os botóes florais apresentaram até cinco orifícios de oviposição.

Pessoa et al. (1993b), Ramalho et al. (1993b) e Pierozzi Jr.; Habib (1993a) sugeriram que a inviabilidade do ovo, a competição intraespecífica, a predação, o parasitismo, a má formaçáo dos indivíduos e as doenças são as principais causas da mortalidade natural dos estágios imaturos do bicudo-do-algodoeiro. Ramalho et al. (1993a, 1993b) e Ramalho; Silva (1993) concluíram que, além do parasitismo e da predação, a dessecação dentro dos botôes florais caídos no solo também é uma das causas da mortalidade, sendo a mortalidade mais alta na fase larval.

\section{PLANTAS HOSPEDEIRAS}

No Brasil, o bicudo-do-algodoeiro apresenta alguns hospedeiros alternativos que são responsáveis pela sua sobrevivência no período de entressafra (NAKano et al., 1987). As espécies Hibiscus tiliaceus, Hibiscus rosa-sinensis, Hibiscus schizopetalus, Malvaviscus arboreus, Abutilon striatum (Gabriel, 2002a), Hibiscus sabdariffa, Abelmoschus esculentus, Hibiscus syriacus e Thespesia populnea (Gabriel, 2000, 2002b, 2002c) foram citadas como hospedeiras alternativas de $A$. grandis no Brasil.

Gabriel $(2000,2002 c)$ avaliou a biologia de $A$. grandis nos hospedeiros alternativos $H$. tiliaceus, $H$. rosa-sinensis, H. schizopetalus, H. sabdariffa, A. esculentus e G. hirsutum e observou que o bicudo pode se desenvolver em todas as espécies estudadas, porém, o peso médio dos adultos foi inferior em relaçáo ao do bicudo no algodáo em campo e as fêmeas náo ovipositaram. Dentre os hospedeiros testados, H. rosa-sinensis apresentou maior porcentagem de adultos, menor ciclo de vida, maior longevidade e adultos com peso médio perto do padrão de G. hirsutum. De acordo com Gabriel (2002a), os bicudos alimentados com $H$. tiliaceus foram mais longevos, senda essa planta capaz de manter os bicudos vivos por 131,6 dias em média. Para espécies M. arboreus e A. striatum, Gabriel (2002a) relatou que os bicudos machos viveram, no máximo, respectivamente, 42 e 17 dias, enquanto que para as fêmeas esses valores foram de 95 e 50 dias. Gabriel (2002b, 2002c), avaliando a oviposição de $A$. grandis em $H$. rosa-sinensis, $H$. schizopetalus, H. tiliaceus, H. sabdariffa, H. syriacus, A. esculentus, M. arboreus e T. populnea, também concluiu que essas malváceas não são hospedeiras reprodutivas do bicudo-do-algodoeiro.

Ribeiro et al. (2010), analisando o conteúdo do trato digestivo dos adultos do bicudo capturados em áreas de Cerrado em campos de algodáo, relataram que ele se alimenta do pólen de 19 famílias de plantas, de uma Pteridophyta, de esporos de fungos e de cistos de algas. De acordo, tais autores, no início do ciclo do algodão, as famílias de plantas Poaceae, Malvaceae, Smilacaceae, Asteraceae, Fabaceae, Clusiaceae são utilizadas como fonte de pólen para adultos de bicudo nos campos de algodão. Em área de Cerrado os mesmos autores relataram que bicudos se alimentam de Chenopodiaceae e Scheuchzeriaceae, e, após a colheita, Smilacaceae é a família predominante entre as plantas alimentares exploradas pelo inseto.

VIDAl et al. (2010) testaram as plantas feijão-de-corda, margaridão, milheto, quiabo, soja e sorgo como hospedeiras alternativas dos adultos de bicudo, visando ao uso dessas como cultura armadilha, e observaram que apenas o quiabo, o sorgo e o margaridão mantiveram $50 \%$ dos bicudos vivos por mais de sete dias. Resultados desses autores sugerem que o quiabo é um candidato para o desenvolvimento de uma cultura armadilha, devido à alta longevidade dos bicudos alimentados com as flores frescas dessa malvácea. Gravena (2001) citou malváceas dos gêneros Thespesia, Cienfuegosia e Hampea como hospedeiras verdadeiras do bicudo, pois nelas o inseto consegue se reproduzir como em algodáo.

\section{DINÂMICA POPULACIONAL}

De acordo com Degrande (2000), o período de ataque do bicudo às plantas de algodoeiro se inicia por volta dos 
30 dias após a emergência, no estabelecimento vegetativo da cultura, passando pelo florescimento e frutificação e chegando até a fase de maturação, aos 140 dias. Ramalho et al. (1990) concluíram que o período crítico do algodoeiro herbáceo ao ataque do bicudo ocorre entre o surgimento dos primeiros botôes florais até o aparecimento dos primeiros capulhos. Habib; Pierozzi JR. (1986) estudaram a flutuação populacional de $A$. grandis na região de Campinas, Sáo Paulo, por meio do monitoramento de adultos livres em plantas ou capturados em armadilhas de feromônio e pela infestação em botóes florais e maçâs de algodoeiro. Esses autores relataram que o ataque iniciou aos $50 \mathrm{a}$ 60 dias após o plantio com reduzidos índices populacionais; o índice populacional manteve-se abaixo do nível de dano econômico até a colheita, devido ao programa de manejo utilizado na área. Com o rebrotamento das plantas, ocorreu o aumento da populaçáo, que diminuiu gradualmente no período de entressafra, até recomeçar a infestação da cultura no ciclo seguinte. RAmiro et al. (1989) relataram que no município de Artur Nogueira, Sáo Paulo, os danos ocasionados pelo bicudo começaram a aparecer no final de dezembro, aumentando no início de janeiro e fevereiro, respectivamente para as safras 1987/1988 e 1988/1989. Esses autores ressaltaram que a dinâmica populacional do inseto na cultura pode variar de regiáo para regiáo e de um ano para outro, devido à dinâmica do inseto na entressafra e às condiçóes climáticas do período. Azevedo; Vieira (2002) relataram que o clima quente e seco do Vale do Curu, Ceará, reduziu a densidade populacional do bicudo, que danificou somente $4 \%$ dos botôes florais em estudo realizado na regiáo em 1999.

Conforme Gravena (2001) e Bianchini (2004), os bicudos adultos que infestam a cultura inicialmente atraem outros por meio dos feromônios que liberam. Eles rapidamente se alimentam e ovipositam na periferia da cultura originando, em reboleiras, os primeiros ataques em botôes florais. Então, aos 40 ou 60 dias após a emergência das plantas, os insetos da primeira geração váo se distribuindo por toda a cultura, caracterizando uma infestação das bordas para o centro da lavoura (Bleicher; Almeida, 1989, 1991; Paron et al.,1993a; Santos, 2002; Bianchini 2004; Busoli; Michelotto, 2005; TomQuelski; Martins, 2008). Ribeiro et al. (2004) coletaram bicudos em uma área de Cerrado próxima a um campo de algodáo, sugerindo que no período da entressafra esse inseto se abriga em refúgios esperando um novo plantio de algodáo e depois se desloca para a cultura, aumentando o ataque no período de desenvolvimento de estruturas reprodutivas do algodoeiro. Santos (1993) observou bicudos colonizando plantas de algodoeiro com 30 dias de idade, antes mesmo da formação dos botôes florais, sendo que a infestação teve início nas bordaduras localizadas próximas às áreas de refúgio da entressafra. Rodrigues et al. (2011) concluíram que na região do Mato Grosso o bicudo prefere se instalar na entressafra do algodoeiro em área de Cerrado do que em área de mata.

Gabriel (1984a, 1984b), realizando estudos no estado de São Paulo, relatou que no período da entressafra (209 dias) em 5 armadilhas de feromônio com raio de açấo de $200 \mathrm{~m}$ foram coletados 33 mil bicudos, o que representa um alto potencial de infestação, sendo que a média diária de captura de cada armadilha foi de 40,3; 38,3; 43,9; 11,5 e 26,2 adultos, em cada armadilha.

Silva Filho; Снатв (1987), realizando o monitoramento de $A$. grandis na reserva biológica de Mogi-Guaçu, Sáo Paulo, utilizando armadilhas de feromônio, observaram que no mês de março ocorreu um aumento do número de insetos capturados, havendo maior incidência nos meses de junho e agosto, coincidindo com o período de entressafra. Nos meses seguintes ocorreu uma diminuiçấo do número de insetos capturados, chegando a níveis próximos de zero no mês de dezembro e janeiro.

Vieira et al. (1991a) relataram que, no Ceará, A. grandis colonizou o algodoeiro cultivado em condiçóes de sequeiro aos 50 dias de idade da planta, sendo que nesse período o nível de infestação chegou a $6 \%$ de botóes florais atacados. Quando a cultura completou 85 dias, o nível de infestação chegou a $25 \%$ e permaneceu assim por aproximadamente 30 dias. Em estudo de monitoramento, realizado em São Paulo, nas coletas utilizando armadilhas de feromônio grandlure observou-se que a infestaçấo inicial do bicudo em algodoeiro ocorreu 43 dias após a germinação das plantas. Em coletas realizadas na planta, o primeiro adulto foi encontrado aos 78 dias (Busoli et al., 1991). Vieira et al. (1993) relataram um maior percentual (22\%) de infestação do algodoeiro por $A$. grandis aos 105 dias.

Braga Sobrinho et al. (1991), estudando a dinâmica populacional de $A$. grandis em diferentes áreas produtoras de algodão do Nordeste brasileiro, relataram que iscas de feromônios foram relativamente pouco atrativas durante o desenvolvimento da cultura e altamente eficazes durante a fase de maturação do algodoeiro. Esses autores relataram também que o pico populacional do bicudo-do-algodoeiro ocorreu nos meses de agosto a setembro, nos quais foram capturados de 200 a 9.000 bicudos por área, utilizando iscas de feromônio e inseticida nas armadilhas.

Belorte; Ramiro (1993) constataram que na regiáo do município de Bilac, São Paulo, A. grandis iniciou a colonização do algodoeiro em janeiro, sendo que o número de insetos se manteve em baixas quantidades durante todo o período. Em Araçatuba, São Paulo, os mesmos autores relataram uma alta porcentagem de botôes com danos já no aparecimento dos primeiros botóes. Essa porcentagem foi aumentando semanalmente, sendo que no final da safra a área estava com $75 \%$ dos botóes danificados por postura ou alimentação. Na região de Jaboticabal, São Paulo, PARON et al. (1993a) relataram um grande número de 
adultos de $A$. grandis coletados na safra 1991/1992 por armadilhas de feromônio nos meses de maio a julho, já em agosto esse número diminui, o que também ocorreu com o peso dos insetos.

Chaib; Luporine (1987) concluíram que existem duas formas de ataque de bicudo nas lavouras de algodão, o ataque "de foco", que ocorre a partir dos 35 a 40 dias da germinação, e o ataque "de migração", que ocorre a partir dos 80 a 100 dias da germinação, dependendo da época de plantio, que na prática corresponde às reboleiras e à colonização da área, respectivamente. Avaliaçóes de Ribeiro et al. (2006a) mostraram que o bicudo atacou preferencialmente botões em abril $(38,9 \%)$ e maio $(43,2 \%)$, porém, esse padrão mudou em junho, quando somente 4,9\% dos botóes foram atacados. De forma inversa, o ataque nas maçãs cresceu de 1,0\% em abril para 19,2 e 45,1\% em maio e junho, respectivamente. Esses autores concluíram que essa troca no padrão de preferência pelas estruturas atacadas pode refletir uma estratégia de distribuição de risco em relação à sobrevivência durante a entressafra, pois os insetos que se desenvolvem nos botóes obrigatoriamente deixam a estrutura quando atingem a fase adulta, enquanto que aqueles que se desenvolvem nas maçãs podem atravessar ali o período de entressafra da cultura do algodão.

Contrariando a maioria dos estudos, Chagas et al. (2010), estudando a flutuação populacional do bicudo no município do Cristalina, Goiás, não coletaram adultos no início da safra (janeiro a março) em dois anos de coleta, sendo que a população aumentou gradativamente a partir de abril e atingiu o pico de ocorrência em maio. $\mathrm{Na}$ região de Itiquira, Mato Grosso, Scomparin et al. (2005b) observaram picos populacionais de adultos nas épocas de floração seguindo até a colheita, sendo que as larvas apareceram em grande quantidade principalmente de maio a junho. Segundo Nogueira et al. (2005), na região de Dourados, Mato Grosso do Sul, a flutuação populacional do bicudo demonstrou ser baixa na fase de desenvolvimento da cultura, apresentando picos de capturas elevados no final de ciclo (cut-out), após a cultura ter sido roçada (destruição das soqueiras) e durante o preparo do solo nas áreas circunvizinhas às armadilhas (início da primavera).

Ribeiro et al. (2006b) relataram que a maior parte da população do bicudo permanece nos restos culturais durante a entressafra o que, segundo Nakano (2006), contribui para que a praga permaneça em atividade durante o ano todo. BiAnCHINi (2004) relatou que a rápida capacidade de reprodução desse inseto permite que em um único ciclo da cultura do algodão sete geraçóes dessa praga possam ser obtidas. Os resultados de Bravo et al. (2010) mostraram que os adultos do bicudo saem dos botóes florais e das maçãs-do-algodoeiro caídas no solo no máximo 42 dias após a incubação, antes que o algodoeiro finalize o ciclo, considerando pouco provável que a recolonização das áreas da safra seguinte venha das estruturas remanescentes no solo.

\section{DANOS ECONÔMICOS}

A população do bicudo-do-algodoeiro, quando não controlada, pode destruir completamente a produçáo de um algodoal (BAstos et al., 2005). Essa grande capacidade de destruição está ligada ao expressivo dano por indivíduo, grande capacidade de proliferaçáo e disseminação no campo (Degrande, 1994; Degrande et al., 2001; Nakano, 2006; Brugnera, 2009; Silva, 2012). Segundo Degrande et al. (2004) e Degrande (2006), as lavouras de algodão sofrem prejuízos que variam de 3 a $75 \%$ da produtividade esperada, sendo as perdas da ordem de US\$ 140 a 350 por hectare/ano, incluídos os danos, custos de controle e depreciaçáo da infraestrutura de combate da praga.

Os principais danos causados pelo bicudo no algodoeiro são resultantes de orifícios promovidos nas estruturas reprodutivas da planta durante a alimentação e oviposição dos adultos do inseto, sendo os botóes florais as estruturas preferencialmente atacadas pelos insetos (TomQuelSKi; Martins, 2008; Araújo et al., 2010; Silva 2012). Grigolli et al. (2011) verificaram que os botôes florais presentes no terço médio das plantas são os preferidos para a alimentação, enquanto que os botóes florais presentes no terço superior das plantas são os preferidos para a oviposição. Porém, na ausência dos botōes florais e em alta densidade populacional de adultos, as flores (Nakano, 2006; CARVALho et al., 1984) e as maçấs também podem ser atacadas (GravenA, 2001; Busoli; Michelotto, 2005). Para Moreira et al. (1994) e Araújo (2010), o bicudo também é um dos principais responsáveis pelo apodrecimento de maçâs, uma vez que seu ataque favorece a penetração de fungos e bactérias nesses frutos.

Os ataques decorrentes da alimentação são reconhecidos pela presença de um orifício de mais ou menos $1 \mathrm{~mm}$ de diâmetro e profundidade variável, geralmente contendo em sua volta um anel amarelo formado por grãos de pólen (Santos, 2002; Busoli; Michelotto, 2005; TomQuelski; Martins, 2008). Os ataques de oviposição de adultos se caracterizam pela presença de uma espécie de revestimento de cera na entrada do orifício, feito pela fêmea (SANTOS, 2002; Busoli; Michelotto, 2005). Essa cera é formada por uma mistura de substância antimicótica e resíduos provenientes de botão floral e forma uma protuberância ou calo no orifício, que serve de proteçấo contra inimigos naturais e evita a desidratação do ovo (Tomquelski; Martins, 2008; Silva, 2012). A postura em geral é feita na base dos botóes florais, havendo geralmente um ovo por botão (ToMQUeLsKi; Martins, 2008). Dentro das estruturas reprodutivas do algodoeiro ocorre todo o desenvolvimento larval, pupal e a 
formação do adulto (SANTOS, 2002; NAKANO, 2006). As larvas se alimentam de todo o interior do botão, que cai no solo aproximadamente após 5 a 9 dias (SANTos, 2002; Busoli; Michelotto, 2005; Silva, 2012). No interior do botão, sobre o solo, as larvas completam seu desenvolvimento, tornam-se pupas e posteriormente adultos (SANTOS, 2002).

De acordo com Santos et al. (2003), o principal alvo de alimentaçáo do bicudo nos botôes florais são as anteras e os óvulos; ainda segundo esses autores, o processo de alimentação é preferencialmente iniciado nas sépalas e pétalas mais novas, e inclui a perfuraçáo dos tecidos e posterior mastigação dos estames e do ovário, levando consequentemente à abscisão da estrutura floral. A abscisão do botão floral é ocasionada pelos compostos proteicos endopolimetilgalacturanase liberados pelas larvas do $2^{\circ}$ e $3^{\circ}$ ínstar. Depois disso, o botáo usa a água vascular e inicia o processo de secamento. Flores atacadas ficam com aspecto de baláo, devido à abertura anormal das pétalas, e apresentam perfuraçóes (TomQuelski; Martins, 2008). Quando as maçâs são alvo do ataque, elas se abrem irregularmente, ficando deformadas, mas permanecendo ligadas às plantas (carimâs), além de apresentarem fibras manchadas, o que aumenta a impureza do algodáo e prejudica a qualidade para comercialização (Degrande et al., 2001; Degrande, 2002; Tomquelski; Martins, 2008).

Em estudo realizado por Busoli et al. (1991), a porcentagem de botôes danificados (oviposição ou alimentaçẫo) por $A$. grandis foi de $17 \%$ em plantas entre os 78 e 89 dias após a germinação, sob uma densidade populacional entre 1 a 4 adultos/100 plantas. Enquanto a porcentagem de botóes no solo devido à incidência de bicudos foi de $40 \%$. CARVAlHo et al. (1993) observaram uma maior porcentagem de estruturas atacadas no solo $(41,53 \%)$ em relação às das plantas (35,23\%). Busoli et al. (1991) observaram que as maçãs foram atacadas somente no ponteiro e aos 137 dias após a germinação, encontraram em média 1,5 larvas por maçá. Posteriormente, Busoli; Michelotto (2005) relataram a preferência de alimentação de $A$. grandis pelas estruturas reprodutivas mais novas do algodoeiro, uma vez que as maçâs a partir de 12 dias sáo menos danificadas, pois, segundo os autores, os tecidos de exocarpo estão mais resistentes à penetração do aparelho bucal do inseto, enquanto que as maçãs mais novas apresentam maior percentagem de ataque e o dobro do número de orifícios.

Gabriel; Dias Neto (1989) e Gabriel et al. (1992) observaram que a queda das maçấs ocorre 15,8 dias após $o$ ataque, enquanto que a dos botóes florais ocorre aos 6,3 dias. No entanto, Broglio-Micheletti (1991) observou um período de 5 a 9 dias para queda dos botóes florais. Posteriormente, Gabriel et al. (1991b) concluíram que a queda ocorre em um período superior a sete dias após o ataque. Gabriel; Dias Neto (1989) observaram que a queda das maçâs é causada por larvas de $3^{\circ}$ ínstar e a dos botóes florais por larvas de $2^{\circ}$ e $3^{\circ}$ ínstar. Gabriel et al. (1991b, 1992) relataram apenas larvas de $3^{\circ}$ ínstar como responsáveis pela abscisão dos botóes florais. Segundo Scarpelini; Busoli (1999), a queda dos botóes florais náo é influenciada pela infestação do bicudo no início do florescimento, apenas a partir dos 80 dias após a emergência das plantas é que a emissão de botôes florais/planta diminuiu e o nível controle do inseto é atingido rapidamente.

Em trabalho realizado por Fernandes et al. (1991), visando verificar a preferência alimentar e de oviposição, foi observado que $A$. grandis preferiu atacar botóes florais localizados na regiáo do terço médio, o que acarretou elevada abscisão e maior distribuição dos frutos no terço inferior das plantas. Em estudos de Carvalho; Santos (1998), a preferência de ataque foi por botóes florais localizados no terço superior das plantas, enquanto no terço médio as estruturas mais atacadas foram os frutos.

Fernandes et al. (1991) não observaram preferência por alimentação e oviposição entre flores e frutos, sendo ambas as estruturas atacadas. Após o ataque do bicudo, o tempo para abertura e amarelecimento das brácteas e queda dos botôes foi, respectivamente, de 6,1; 7,5 e 10 dias (Almeida et al., 1997). Carvalho; Santos (1997) observaram que os botôes florais foram as estruturas mais atacadas tanto quando caídas no solo $(75,2 \%)$ como na planta $(79,8 \%)$, o que resultou em uma baixa produçáo de frutos. A cada $1 \%$ de botôes florais danificados por $A$. grandis há um decréscimo na produção da ordem de 33,1 kg/ha (Gielfi; Busoli, 1998a, 2000) de algodão em caroço.

Santos (1993) relatou adultos de $A$. grandis se alimentando do algodoeiro antes mesmo do aparecimento dos botôes florais. Os ataques foram oriundos de perfuraçôes no ápice do caule e nos pecíolos, levando ao murchamento, seca das folhas e bifurcação das hastes em função da morte da gema apical da planta.

Ribeiro et al. (2005b), em seus estudos, concluíram que o bicudo foi capaz de encontrar e colonizar uma área de plantio isolada e distante $70 \mathrm{~km}$ das áreas de plantio de algodão, aumentando progressivamente sua população na primeira geração, estabelecendo-se na cultura e causando danos pelos orifícios de alimentação e de oviposição acima do nível de controle de $10 \%$. Comparando as taxas de ataque, Chagas et al. (2010) observaram que parcelas próximas ao Cerrado não diferiram daquelas próximas a outras áreas, sugerindo que os danos produzidos pela praga não estejam relacionados à fisionomia vegetal do entorno.

\section{NÍVEL DE DANO ECONÔMICO}

As determinaçôes do nível de ação e de dano econômico são fundamentais para o sucesso de programas de MIP 
(Gielfi; Busoli, 1998b). De modo geral, para o período anterior à expansão dos algodoais para o Cerrado do Brasil, os níveis de controle indicados variavam de 5 a $15 \%$ de botóes florais com ataque; já após a fase de modernização da cotonicultura com maiores índices de produtividade, posteriormente ao ano de 1996, as indicaçóes são de 5\%, ou baseadas em armadilhas de feromônio (Degrande et al., 2003; Degrande, 2004b).

Para Gielfi; Busoli (1998b; 2000), níveis de infestação entre 5 e $10 \%$ de botôes florais danificados são adequados para o controle de $A$. grandis. Degrande (1993) concluiu que um nível de controle de $5 \%$ de botôes danificados (até a primeira flor) e 10\% (após) permitiu segurança a um sistema de MIP proposto, para os padróes tecnológicos regionais da época. Nakano (1999) preconizou que deve ser contado o número médio de maçâs/planta, sendo que cada maçã em formação ou formada/planta corresponde à porcentagem de infestação tolerada. De acordo com esse autor, a proteção é feita em função das maçâs obtidas, quanto maior o número de maçẫs existentes, significa que a produção já está garantida e, portanto, a tolerância à praga é maior.

SANTOS et al. (1991) observaram que, mesmo em situaçóes altas de porcentagens de danos, um controle que mantenha um nível de dano econômico ao redor de 10 a 15\% garante uma produçáo relativamente boa. RAMALHO et al. (1990) concluíram que podem ser utilizados como nível de controle do bicudo $10 \%$ dos botôes florais danificados (com orifício de oviposição). Posteriormente, Degrande et al. (2003) e Degrande (2004b) recomendaram adotar o nível de controle de $5 \%$ de botôes florais atacados (presença do inseto e/ou danos de alimentação mais oviposição), pois se o nível de infestação for superior a 5\% o dano econômico é maior do que o custo de controle.

\section{AMOSTRAGEM}

Segundo SANTOS (2002), nas amostragens deve-se observar a presença de danos em botôes florais, sendo mais comum encontrar os orifícios de alimentação, e em menor proporção orifícios para a oviposição. Esse autor ressalta ainda que nas inspeçôes de campo devem-se tomar amostras nas bordaduras em separado do restante da área cultivada.

Kиво et al. (1987) relataram a utilização de exame visual de plantas, armadilhas de solo (pitfall), coleta e observação em laboratório de botóes florais caídos no solo como métodos de amostragem de $A$. grandis e de seus respectivos predadores, parasitoides e patógenos. Visando avaliar a população de $A$. grandis que se dispersa para o algodão no início de seu ciclo, Silveira Neto; Ambrozano (1987) utilizaram a técnica de marcação, soltura e recaptura e obtiveram populaçôes iniciais entre 51 e 535 bicudos se dispersando para o algodão em diferentes anos.
As armadilhas de feromônio grandlure para o monitoramento do bicudo detectam o início da colonização e auxiliam na determinação da época adequada para o controle da praga. Segundo Rodrigues; Miranda (2007), essas armadilhas começaram a ser utilizadas no Brasil logo após a introdução da praga no país. De acordo com Degrande (2004a), em programas de controle, as armadilhas de monitoramento cumprem seu papel até a data da emergência da lavoura, podendo ficar instaladas até a primeira flor aberta para contribuir com as informaçóes relacionadas ao movimento e à distribuição da população do bicudo e entâo devem ser recolhidas e guardadas. Ainda segundo esse autor, as armadilhas são excelentes ferramentas auxiliares para informar, previamente, o aparecimento do bicudo na lavoura, qual a pressáo populacional da praga e por onde ele tem potencialmente mais chance de entrar.

Degrande (2002) relatou que o controle deve ser feito em área total quando até $5 \%$ dos botôes florais estiverem atacados (presença da praga, oviposição ou danos de alimentação), sendo que para amostragem deve-se avaliar um mínimo de 250 botôes florais das plantas "dominantes" (maiores) por talhão.

Ribeiro et al. (2005b) realizaram o monitoramento conforme o número médio de bicudos capturados por armadilha por semana (BAS). Esses autores realizaram o armadilhamento de pré-safra, o que permitiu categorizar os talhōes em função da infestação e através da categorização em cores foi possível tratar diferentemente os talhóes. Essas estratégias permitiram obter produçóes mais econômicas, uma vez que se aplicou inseticida onde era realmente necessário.

\section{CONTROLE COMPORTAMENTAL}

Ambrogi et al. (2009) afirmaram que o bicudo foi o primeiro curculionídeo a ter o feromônio estudado, o qual é constituído de quatro componentes, os álcoois 2 e 3 e os aldeídos 5 e 6 . Segundo esses autores, formulaçôes sintéticas do feromônio do bicudo liberado pelos machos em testes atraem tanto machos como fêmeas no campo. Naturalmente, o feromônio é produzido pelos machos do bicudo e liberado nas fezes após se alimentarem de algodoeiro no início da safra, com o objetivo de facilitar que outros bicudos encontrem a lavoura e também de favorecer a aproximaçáo dos sexos para o acasalamento (Degrande et al., 2004; Rodrigues; Miranda, 2007).

O feromônio do bicudo, o grandlure, foi sintetizado industrialmente e é usado comercialmente em armadilhas de atraçáo, captura e monitoramento (Degrande et al., 2004). Essas armadilhas são referidas como instrumentos eficazes em programas de detecção e monitoramento do bicudo tanto em programas de manejo como em programas 
de supressão (Braga Sobrinho; Lukefahr, 1984b; Habib et al., 1984a; Degrande, 1999; Fernandes et al., 2006). Segundo Rodrigues; Miranda (2007), a eficiência da armadilha com feromônio pode ser influenciada por fatores como cor, forma, localização, competição com bicudos machos, fatores climáticos e condições fisiológicas do bicudo. FERnANDes et al. (2006) relataram que o número de bicudos capturados pelas armadilhas de feromônio pode ser utilizado como indicativo da quantidade do inseto praga nas parcelas, auxiliando na tomada de decisão quanto à realização de pulverizações para o controle, possibilitando a redução do custo de produção e uma maior preservação do ambiente e dos organismos benéficos do dossel da planta e da superfície do solo. Vilela (1992) afirmou que é corrente o uso do feromônio do bicudo no Brasil e, segundo Gabriel (1984a, 1984b), as armadilhas de feromônio são adequadas para controle desse inseto no período da entressafra.

Segundo Degrande et al. (2004), a armadilha é composta por uma base plástica verde, considerada a cor mais atrativa, de formato cônico, com o topo achatado que acopla um funil telado cuja parte superior recebe um receptáculo plástico onde deve ser colocada a pastilha de feromônio. Rodrigues; Miranda (2007) sugeriram que as armadilhas sejam colocadas em campo aberto, longe de galhos e cerca de 1,4 $\mathrm{m}$ acima do nível do solo, já a distância entre as armadilhas deve ser entre 150 e $250 \mathrm{~m}$ ao longo do perímetro das áreas cultivadas com algodão para obtenção de resultados satisfatórios.

Braga Sobrinho; Lukefahr (1984b) modificaram armadilhas de feromônio do tipo "Hardee", aumentando a aeração da câmara receptora da isca de feromônio e aumentando o número de orifícios de entrada de adultos na armadilha. Essas modificaçóes aumentaram em 2,5 vezes o número de insetos coletados quando comparadas a armadilhas sem as modificações. Coutinho; Cavalcanti (1988) afirmaram que o aumento no número de orifícios nas armadilhas, com a finalidade de aumentar o arejamento e consequentemente a dispersão do feromônio, promoveu um incremento de captura de bicudos em 100\%.

GABRIEL (1986) avaliou a eficácia de propoxur 10\%, proveniente de coleira antipulgas e carrapatos para cães, como substituto para o inseticida importado, utilizado em armadilhas com feromônio. Avaliado nas formas fragmentado e triturado, apresentou índice de mortalidade elevado (maior do que 95\%), sendo que na forma triturada foi ligeiramente superior à fragmentada.

Aquino et al. (1986) concluíram que a armadilha de feromônio do tipo "Hardee" captura mais fêmeas de $A$. grandis do que machos, podendo também capturar insetos de outras ordens. Além disso, esses autores relataram que as armadilhas usadas (bulbos e funis escuros, devido ao efeito da radiação solar) são tão eficientes quanto as novas na captura do bicudo, mas ressaltaram que periodicamente deve ser feita a limpeza do orifício de entrada do cone da armadilha, no qual aranhas se alojam e tecem teias, reduzindo a entrada de insetos e a eficiência da armadilha.

De acordo com Coutinho; Calvancanti (1988), a utilizaçáo conjunta de iscas de feromônio e iscas de inseticida evita a evasão dos insetos capturados na armadilha de feromônio, quando utilizada para monitoramento, aumentando sua eficiência. NogueIra et al. (2005) relataram que a utilização da pastilha tóxica colocada na armadilha melhora de forma significativa o aprisionamento do número de bicudos capturado. PApA et al. (1984) relataram ainda que o uso do feromônio grandlure para agregação dos bicudos, associado à aplicação de inseticida paration, apresentou eficiência superior a $80 \%$ na eliminação do bicudo em relação às aplicaçóes nas quais se utilizou apenas o inseticida. SAnTos (1997) fez a associação do feromônio sexual grandlure ao inseticida cipermetrina e obteve maior produtividade e menor índice de ataque em botóes $(10,8 \%)$ em relação ao controle químico convencional, no qual o nível de botóes danificados chegou a 59,44\%; além disso, as aplicaçóes do feromônio na bordadura retardaram o avanço do bicudo para o interior da cultura.

Melo et al. $(1986,1987)$ relataram que as formulaçóes do feromônio grandlure tipos "sanduíche" e "capilar" são as mais eficientes para a atração de adultos do bicudo em relação à formulação "bastonete". Esses mesmos autores, comparando a eficiência das armadilhas IAC/Embrapa, Hardee e Hercon, concluíram que o modelo IAC/Embrapa em condiçóes de campo é o mais eficiente na captura dos adultos independente do tipo de formulação utilizada.

НАвів et al. (1984a) relataram a alta eficiência do feromônio grandlure na agregação de adultos, propiciando assim o controle dos insetos em faixas estreitas durante o ciclo do algodão, assim como nas entressafras, semelhantemente ao obtido por PAPA et al. (1984).

Ioneda et al. (1987) relataram que o bicudo-do-algodoeiro foi coletado com o auxílio de armadilhas de feromônio após a colheita com vários picos populacionais até a época de plantio e sugeriram que a não destruição dos restos culturais contribuiu para manter a população dos insetos em níveis relativamente altos.

Para Scarpellini; Ramiro (1997), a tecnologia tipo atrai-e-mata em tubos-isca é mais eficiente do que a própria cultura-isca, pois retardou a infestação na lavoura, diminuiu a porcentagem de botóes atacados e também reduziu o número de aplicaçôes com inseticidas, gerando uma produção superior. CASTILHO et al. (2004a) relataram que o dispositivo tubular atrai-e-mata, baseado em feromônio, óleo de algodão e malation aplicado num tubo de papeláo foi eficiente para reduzir populaçóes remanescentes do bicudo em períodos de entressafra. De acordo com CASTilho et al. (2004b), a instalação desses tubos na semeadura do algodão é uma estratégia eficiente e contribui para a redução dos danos da praga.

Em estudo realizado por VIVAN (2009), a populaçáo de bicudos apresentou redução nas áreas com instalação de 
tubos-isca no período de entressafra, com população média de 1,8 bicudos/armadilha durante o período de 7 semanas, já a área sem a instalação de tubos-isca apresentou população média de 5,4 bicudos/armadilha durante o mesmo período. Esse fato demonstra que a utilização desse dispositivo tubular durante o período da entressafra do algodoeiro auxilia na redução populacional do inseto se instalado aos 60 dias antes do plantio e no cultivo seguinte.

SANTOS et al. (2002) afirmaram que dispositivos tubulares à base de feromônio grandlure, do tipo atrai-e-mata, foram eficientes na atração e no controle do bicudo, e em casos onde a esse dispositivo foi associado adesivo autocolante ou óleo de algodáo, a retençáo do bicudo aumentou 11 vezes. Fernandes et al. (2001) concluíram que, no período de entressafra, os adultos de $A$. grandis foram atraídos imediatamente após a aplicação do feromônio grandlure, mantendo-se a captura por mais de 14 dias após; e o índice mais elevado de atração foi observado 24 horas após a aplicação. Os resultados de Rodrigues et al. (2008) indicaram que tubos similares, colocados a $50 \mathrm{~m}$ de distância da armadilha de feromônio, interferem na captura de bicudos na armadilha, reduzindo o número de insetos capturados. Em adiçâa, segundo Rodrigues; Miranda (2007), o dispositivo tubular que atrai e mata bicudos foi utilizado como medida complementar a outras táticas de controle e resultou em menores infestaçóes do inseto. Quando instalado na época de plantio e na pós-colheita do algodoeiro, esse dispositivo associado ao MIP apresenta eficiência no controle do bicudo, resultando em menor porcentagem de botôes florais danificados, menor número de pulverizaçôes com inseticidas e, consequentemente, maiores rendimentos (Miranda; SiLva, 2005).

SiLva et al. (2006), analisando a eficiência de feromônios, relataram que o feromônio da marca Plato capturou um número significativamente mais elevado de insetos por armadilha do que o feromônio da marca Biocontrole. KLESENER et al. (2010) concluíram que o feromônio Iscalure BW60, em aplicação única 63 dias após instalação das armadilhas, apresentou a mesma capacidade de atração do que o tratamento padrão Plato, que foi trocado 4 vezes (a cada 14 dias).

\section{CONTROLE CULTURAL}

O controle cultural foi implementado no sistema de cultivo do algodoeiro após o surgimento do bicudo, época em que o controle químico dessa praga ainda náo estava totalmente disponível (Bastos; Almeida, 2005).

A adoção de práticas culturais adequadas para o controle de $A$. grandis na safra e entressafra é uma das estratégias que pode aumentar a produção de algodão em áreas infestadas por essa praga (Degrande, 1994; Busoli; Michelotto, 2005). Sob a filosofia das práticas culturais, o manejo do bicudo deve ser feito em toda a regiáo e náo apenas por um produtor individual (Degrande et al., 2003; Degrande, 2006; Silvie et al., 2006; Tomquelski; Martins, 2008). Além disso, faz-se necessária a associação de diferentes estratégias de manejo e também o conhecimento da fenologia do florescimento e frutificação das cultivares de algodoeiro utilizadas na regiáo, assim como a biologia e o comportamento de alimentação e oviposiçáo do inseto (Busour; Michelotto, 2005).

Dentre as táticas de manejo cultural citam-se a precocidade dos cultivares, uniformidade na data de plantio, destruiçáo das soqueiras (Tomquelski; Martins, 2008), semeadura em época recomendada para cada região, instalação de plantio-isca, aplicaçấo de inseticidas nas bordaduras, catação e destruição de botôes florais, utilização de reguladores de crescimento visando aperfeiçoar o controle químico, instalação de tubos atrai-e-mata nas fases pré-semeadura e pós-colheita e preparo do solo (Degrande, 1994, 1999, 2006; Santos et al., 2002; Silva et al., 2004; Busoli; Michelotto, 2005; Silva et al., 2009a).

A precocidade dos cultivares é uma importante estratégia de manejo que pode ser utilizada pelos produtores (Degrande, 1999; Santos, 2002; Degrande et al., 2001, 2003; Soares; Silva, 2003; Silva et al., 2004; Busoli; Michelotto, 2005). De acordo com Degrande (1994, 1999) e Busoli; Michelotto (2005), genótipos de algodoeiro que apresentam rápida frutificação formam a carga mais cedo e possuem maior probabilidade de completar o ciclo, escapando dos elevados índices populacionais do bicudo, que normalmente ocorrem na fase final do ciclo das plantas.

A uniformidade na data de plantio, regionalmente, também é uma prática recomendada para o manejo desse coleóptero, pois estágios de desenvolvimento (e geraçôes) uniformes facilitam o controle da praga (GABRIEL et al., 1997; Degrande, 1994, 1999; SAntos, 2002; Degrande et al., 2003; Soares; Silva, 2003; Silva et al., 2004; Silvie et al., 2006). Silva et al. (2002) e Soares; SiLVA (2003) concluíram que o plantio do algodoeiro em épocas diferentes proporciona o aumento da populaçáo do bicudo-do-algodoeiro e o decréscimo significativo na produçáo. GABRIEL et al. (1997) relataram que em áreas com infestação de $A$. grandis sobre controle o plantio no mês de outubro gera a maior produtividade. Soares; Araújo (1993), comparando três épocas de semeadura de algodão, observaram que o número de maçấs por planta, que era 12 em outubro, diminuiu para 3 em novembro e que em dezembro não houve produção de maçãs devido ao ataque do bicudo.

A instalação antecipada da cultura funciona como um atrativo para os bicudos de entressafra permitindo sua multiplicaçáo, logo, lavouras precoces podem se tornar foco da praga para as áreas cultivadas nas épocas recomendadas (Degrande, 1994). Por outro lado, o plantio tardio do algodáo, fora do calendário regional, de acordo com Degrande 
et al. (2003) e Degrande (1994, 2004a), propicia o aumento do número de geraçóes do bicudo e a dispersão para áreas vizinhas, exigindo mais controle, maiores custos, causando mais danos ao meio ambiente e prejuízos ao sistema regional. De acordo com Araújo et al. (1993a), o plantio tardio à época (nos meses de novembro e dezembro) aumentou o ataque do bicudo, o que resultou em intensa queda dos botóes florais e redução no número de maçãs formadas.

A eliminação de restos culturais do algodoeiro após colheita, de maneira mecânica ou química, também é uma prática recomendada, pois limita o desenvolvimento do bicudo na soqueira e/ou impede a diapausa ao final da safra (DEGRANDE, 1994, 1999; Carvalho, 2001; Degrande et al., 2001, 2003; Bianchini, 2004; Lamas, 2007; Silvie et al., 2006; Chitarra, 2007; Tomquelski; Martins, 2008). Estudos de SoAREs et al. $(1993,1994)$ revelaram a influência das táticas de pós-colheita na captura do bicudo-do-algodoeiro, a combinação de destruição imediata dos restos culturais por roçadeira, seguido de gradagem, mais faixa de soqueira-isca com pulverizaçóes, evidenciam um menor número de insetos capturados em relação aos campos que foram somente roçados ou roçados e gradeados. Além disso, SoAres et al. (1994) afirmaram que a presença de resto de cultura do algodão em fase de produção de botão é um fator que contribui para retenção de bicudos na área, influenciando negativamente na captura das armadilhas com feromônio.

Resultados de Ribeiro et al. (2006b) mostraram que quando as maçãs de algodoeiro com larvas em desenvolvimento são enterradas às profundidades de 5,10 e $15 \mathrm{~cm}$, os insetos não conseguem sair e morrem em seu interior, reforçando a importância da incorporação e da gradagem logo após a colheita do algodáo para o manejo do bicudo. Além dessas práticas, SAntos (2002), Degrande et al. (2001, 2003), Neves et al. (2010) e Neves et al. (2013) sugeriram que a catação das estruturas reprodutivas do algodão caídas no solo e a poda apical demonstram potencial na redução populacional do bicudo. Degrande (1994) recomendou que a catação dos botôes florais seja feita a cada cinco dias, a partir do início da queda dos primeiros botóes, pois essa prática auxilia na redução da praga principalmente na fase de formação da carga. Resultados de Silva et al. (2009a) demonstraram que os menores números de plantas de algodoeiro atacadas pelo bicudo e as maiores produçóes ocorreram nas parcelas nas quais foi realizada a catação de botóes florais caídos ao solo independente do método de controle utilizado. Neves et al. (2010) verificaram que a adoção da catação, da poda apical e de ambas simultaneamente reduziu a população do bicudo em 2,8; 2,5 e 4,8 vezes, respectivamente.

O preparo antecipado do solo em aproximadamente 40 dias desaloja os adultos remanescentes de entressafra na área cultivada, e também é recomendado como prática cultural para controle do bicudo (SANTOS, 2002). SoAres et al. (1995) e SoAres; Busoli (1996) relataram que a utilização de reguladores de crescimento vegetal é outra tática que auxilia no controle do bicudo, pois torna a abertura dos frutos mais uniforme e precoce, antecipando a colheita em 10 a 15 dias, e consequentemente auxiliando no controle do bicudo pela eliminação precoce dos locais de alimentação e oviposiçáo do inseto.

Outra medida de controle cultural que pode ser recomendada para combate ao bicudo é a introdução de soqueiras iscas e culturas-iscas nas bordaduras, ou seja, pequenos plantios de algodão instalados com alguma antecedência em relação às plantaçóes principais e localizadas nas áreas mais próximas às áreas de refúgio dos bicudos na entressafra, como matas e capinzais, para atrair a praga, facilitando seu controle (Santos, 1993; Degrande, 1994, 1999; Degrande et al., 2001; Santos, 2002; Degrande et al., 2003). Degrande (1994) recomendou um intervalo de duas semanas entre a emergência das plantas-iscas e as do plantio definitivo, sendo que as culturas-iscas devem representar $20 \%$ da área total a ser cultivada.

Degrande (1994) recomendou também outras táticas, como a utilização de desfolhante no final da safra, associado a inseticida para redução da população do bicudo de final de safra; a colheita rápida, que permite a destruição precoce dos restos culturais; a rotação e diversificação de culturas, visando à redução das populaçóes de pragas em geral; e a conservação do solo para produção de uma planta equilibrada do ponto de vista nutricional, que suporte maiores pressóes populacionais de pragas.

\section{RESISTÊNCIA DE PLANTAS}

A resistência de plantas de algodão ao bicudo-do-algodoeiro é uma tática de controle importante para a continuidade dos avanços do MIP, pois dispensa conhecimentos científicos profundos do agricultor e contribui para a redução da aplicação de defensivos (Degrande, 2002). Diversos trabalhos foram realizados no Brasil visando encontrar genótipos mutantes de algodoeiro resistentes (VIEIRA et al., 1991b; FARIAS et al., 1993; Lukefahr et al., 1993a; CAsSETARi Neto et al., 2008; Silva et al., 2008).

Em estudo comparando o desempenho das linhagens bráctea frego, folha okra, bráctea frego e folha okra e a variedade CNPA-3H (testemunha) em relação ao bicudo, VIEIRA et al. (1991b) relataram que a linhagem bráctea frego foi a menos preferida e a variedade CNPA-3H a mais preferida pelo inseto, com, respectivamente, 5,22 e 27,39\% dos botóes florais atacados. VIDAL Neto et al. (2005) conduziram testes com chance de escolha e observaram que a característica bráctea frego foi a que apresentou maior redução no dano de oviposição pelo bicudo $(34,71 \%)$ e a folha okra reduziu o dano apenas quando associada à bráctea frego 
(40\%). Esses autores concluíram ainda que a combinação das três características mutantes, bráctea frego, folha okra e planta vermelha, na mesma planta proporcionou a menor porcentagem de botóes com dano de oviposição (23,13\%). Gabriel et al. (2006) e Gabriel; Blanco (2009) observaram que a linhagem IAC-04/227 com característica mutante (planta vermelha) apresentou o menor percentual de botóes florais perfurados pelo bicudo em relação ao cultivar IAC-24 (testemunha) e à linhagem IAC-04/489 (folha okra), indicando que a coloração vermelha das plantas é um caráter importante para resistência do algodoeiro ao bicudo. Silva et al. (2008) também relataram um pequeno número de botôes florais com orifícios de oviposição e alimentação em plantas com o caráter bráctea frego associado à cor vermelha da planta, indicando um efeito cumulativo de não preferência do bicudo por esses fenótipos, sendo que, de acordo com esses autores, a não preferência para postura do bicudo está relacionada à cor vermelha da planta.

SOAREs et al. (1999) consideraram o caráter bráctea frego um dos mais efetivos, citando-o como responsável por reduçôes significativas da oviposição do inseto. A resistência dos genótipos com bráctea frego tem sido atribuída à característica morfológica de formato das brácteas, que atuaria negativamente no comportamento alimentar do inseto. Porém, de acordo com Lopes; LARA (1996), outros fatores, provavelmente químicos, interferem na alimentação do bicudo, pois esses autores testaram botóes florais oferecidos na forma de extrato e observaram que nessa forma os genótipos com bráctea frego (La687FN e Niles Frego) também foram menos preferidos pelo bicudo para alimentação do que os genótipos HG-29 e IAC-20. De acordo com GABriel et al. (2005), a linhagem IAC 04/227 (resultado de transferência do gene de cor vermelha, do genótipo Texas Red, para as linhagens do Instituto Agronômico de Campinas, IAC) foi menos preferida para a alimentação e oviposição do bicudo do que a cultivar IAC-24 quando cultivadas na mesma área.

SoAREs et al. (1999) ressaltaram que, além dos genótipos mutantes, outras fontes de resistência ao bicudo são as raças primitivas ou selvagens. Esses autores relataram que já foram realizados no Brasil vários cruzamentos entre linhagens precoces e raças primitivas, visando uma seleção de cultivares com resistência ao bicudo e com melhor qualidade agronômica. Em testes de cruzamento entre uma variedade de algodão comercial com linhagens silvestres, LukefaHr et al. (1993b) obtiveram um nível médio de resistência. CarvalHo et al. (1996) fizeram vários cruzamentos de acessos de algodão silvestres coletados no México com cultivares Stoneville, PNH3 e CPNA precoce 2 e conseguiram selecionar materiais com resistência ao bicudo e que também apresentavam boas características quanto à produção e a fibra.

Progênies T-1180 (DN) $\mathrm{BC}_{2} \mathrm{~F}_{4}$ e T-326 (DN) $\mathrm{BC}_{2} \mathrm{~F}_{4}$ oriundas de raças primitivas demonstraram reduçóes no número médio de botóes atacados quando comparadas a variedades comerciais (SOAREs et al., 1999). LuKEFAHr et al. (1993b), em trabalhos realizados nos Estados Unidos, relataram que as linhagens de algodão herbáceo Texas 297, 323 e 339 derivadas de raças de algodão silvestres coletados no México e na América Central, indicaram excelentes níveis de resistência ao bicudo, apresentando reduçóes na porcentagem de infestaçóes e número de botôes com orifícios de oviposição. FARIAs et al. (1993) e LuKefahr et al. (1993a), testando as linhagens Texas, observaram redução na porcentagem de infestação e ataque. FARIAs et al. (1999) observaram níveis de resistência ao bicudo nas progênies Texas 326-95-1, Texas 277-87-5, Texas 1180-99-2, Texas 297 e Texas 339 com redução de ataque de 44,0; 41,2; 32,0; 40,4 e 36,4\%, respectivamente, em relação à testemunha CNPA $6 \mathrm{H}$.

LARA et al. (1993) avaliaram a preferência para alimentação de $A$. grandis nos genótipos de algodoeiro Bronze leaf IAC-20, La 780-843FR, La 81-57OFN, TX-LE-2BOS-1-82 e T-277-2-6 e não observaram preferência entre os genótipos. Quanto à preferência para oviposição, esses mesmos autores observaram a não preferência pelos genótipos La 780-843FR e La 81-57OFN (ambos com característica frego). SoAres et al. (1998) testaram a preferência de oviposição e alimentação das fêmeas de $A$. grandis às cultivares comerciais de algodão CNPA- Precoce 2, CNPA-7H e IAC-22 e observaram que não houve preferência por nenhuma das três cultivares testadas. Conforme SoAREs; LARA (1993a), o genótipo La 780-843FR evidenciou os menores índices percentuais de botôes florais atacados pelo bicudo, quando comparado aos genótipos Bronze leaf, IAC-20, La81-570FN, TX-LE-2-BOS-1-82 e T-277-2-6. Soares; LARA (1993b), comparando esses mesmos genótipos, observaram que em testes de chances de escolha os genótipos La 780-843FR, La81-570FN (ambos com característica frego) e T-277-2-6 (raça primitiva) revelaram ser os mais resistentes, apresentando menores danos. Além disso, esses genótipos evidenciaram resistência do tipo não preferência para oviposição e alimentação.

De acordo com Busoli et al. (2004), o cultivar IAC-20 apresentou os maiores valores no número médio de orifícios de alimentaçáo de $A$. grandis quando comparada ao cultivar Reba P288, sugerindo que esse último possa apresentar algum grau de resistência ao bicudo.

Degrande et al. (2002), avaliando os genótipos de algodão herbáceo IAN 338, IAN 93-64, Chaco 520, Cacique, OC 95-621, CD 401, OC 94-146, IAC 96-280, CNPA 7H e CCA 331, observaram que o genótipo CD 401 apresentou menor índice de ataque para o total de maçãs atacadas com orifícios de alimentação e oviposição dentre as caídas sobre o solo e para o total de botóes com orifícios de alimentaçáo e oviposição dentre os caídos na superfície do solo, contudo, para essa última variável, os genótipos 331, IAC 96-280, CHACO 520 e CNPA 7H não diferiram estatisticamente. Ainda de acordo com Degrande et al. (2002), o fato do 
genótipo CD 401 ser o mais precoce em relação aos outros sugere que a não preferência pelo genótipo pode estar relacionado à assincronia fenológica ou evasão hospedeira, que pode ser considerada uma pseudorresistência. SoAres et al. (1999) também citaram a pseudorresistência paras cultivares CNPA Precoce 1 e 2, que apresentavam como vantagem o curto período de floraçáo e frutificaçáo.

Morales et al. (1997) avaliaram a resistência ao bicudo dos genótipos do algodoeiro Sicot 3, Oklahoma Red, Siocra, Paraná 3 e do cultivar IAC-20 (testemunha) e observaram que Sicot 3 apresentou a menor porcentagem de botóes florais atacados $(8,4 \%)$, enquanto que a testemunha apresentou $36,8 \%$ em média. Magalhães et al. (2010) sugeriram que o ataque do bicudo pode desenvolver nas plantas mecanismos de defesa induzida, pois $48 \mathrm{~h}$ após o dano pelo inseto as plantas começam a emitir voláteis. O sistema de cultivo adensado também pode ser utilizado como estratégia contra o bicudo. Resultados de GABRIEL et al. (2011) demonstraram uma maior porcentagem de danos pelo bicudo, para oviposiçáo, no sistema convencional em relação ao adensado, sendo que em relação à produçáo de algodáo em caroço, esta é maior no sistema adensado, enquanto que a porcentagem de fibra é maior no sistema convencional.

Gabriel (1996) relatou que a oviposiçáo do bicudo em botóes florais promove um aumento na densidade dessas estruturas reprodutivas, o que resultou na mortalidade do inseto no estágio de ovo. Este aumento da densidade dos botôes está relacionado a um mecanismo de resistência de plantas, através do qual, a planta prolifera as células do botão floral esmagando os ovos ou larvas do bicudo que estáo em seu interior, promovendo o controle natural do inseto.

\section{CONTROLE BIOLÓGICO E MICROBIANO}

\section{Parasitoides}

Wanderley; RAMAlho (1996) relataram que, no Brasil, 13 espécies de parasitoides foram citadas parasitando $A$. grandis. Esses mesmos autores, citando Ramalho (1994), relataram que na regiāo Nordeste do Brasil, Bracon mellitor e Catolaccus grandis são os principais parasitoides do bicudo-do-algodoeiro.

Gabriel (1992) coletou 334 botôes florais, em área experimental de algodoeiro, cultivar IAC-20, onde não se utilizou inseticida e verificou emergência de 11 espécimes de parasitoides, sendo 10 pertencentes à família Braconidae (Bracon sp.) e 1 à família Pteromalidae.

HaвiB et al. (1984a) relataram Bracon sp. (Hymenoptera: Braconidae) como um ectoparasitoide $A$. grandis e Araújo et al. (1993b, 1999) e PierozZi Jr.; Habib (1993b) estudaram em laboratório os aspectos biológicos desse parasitoide em larvas do bicudo.
Araújo et al. (1997) sugeriram que a liberação de Bracon sp. para o controle biológico do bicudo deve ser realizada a partir da emergência do adulto até o $15^{\circ}$ dia, período em que a sobrevivência do parasitoide foi máxima. Pierozzi Jr. et al. (1984) observaram duas espécies do gênero Bracon parasitando larvas de $A$. grandis, sendo o índice de parasitismo de $54,5 \%$ em um total de 1.026 maçãs coletadas. Além de Bracon sp., Pierozzi Jr.; HabiB (1993b) citam Bracon vulgaris Ashmed (Hymenoptera: Braconidae), C. grandis e Eupelmus cushmani como os principais parasitoides do bicudo.

Araújo et al. (1991, 1993c) avaliaram os aspectos biológicos e comportamentais dos parasitoides B. mellitor (Hymenoptera: Braconidae), C. grandis (Hymenoptera: Pteromalidae), Catolaccus hunteri (Hymenoptera: Pteromalidae) e de uma espécie da família Ichneumonidae em campo e em laboratório, observando que $C$. hunteri prefere larvas de bicudo de primeiro ínstar. Em laboratório os índices de parasitoidismo de C. grandis, Bracon spp., C. hunteri e do Icheneumonidae foram $72 ; 11$; 3 e $57 \%$, respectivamente.

De acordo com Araújo et al. (1991, 1993c), em campo houve predominância de $B$. mellitor e o índice de parasitismo observado em botóes florais e maçãs com larvas foram de 8,5 e 10,9\%, respectivamente. Soares; Lara (1993c), comparando a influência de diferentes genótipos de algodoeiro no nível de parasitismo de $A$. grandis por B. mellitor, concluíram que os genótipos com brácteas do tipo frego favorecem o parasitismo.

Araújo; Azevedo (1997) e Ramalho et al. (1998) consideraram que $C$. grandis é um potencial controlador de A. grandis. Araújo; Azevedo (1997) relataram ainda elevada viabilidade $(96,3 \%)$ do período ovo-adulto do parasitoide em larvas do hospedeiro e também um número superior de ovos/dia produzidos pelo parasitoide em relação ao seu hospedeiro. Conforme Ramalho et al. (1998), a açáo desse parasitoide contra o bicudo não se deve apenas ao parasitismo das suas larvas, mas também à ação das fêmeas adultas do parasitoide, através da injeção de toxinas no corpo de larvas e pupas de $A$. grandis causando a morte.

Dias et al. (1998a, 1998b) relataram os aspectos reprodutivos e a metodologia de criação de Euscepes postfasciatus Fairmaire (Coleoptera: Curculionidae) para sua utilização como hospedeiro alternativo de C. grandis parasitoide de larvas $A$. grandis, visando à produção massal desse parasitoide para liberaçóes em campo em programas de controle biológico aplicado do bicudo. Posteriormente, Dias; Ramalho (2003) afirmaram que, além de E. postfasciatus, outro coleóptero Callosobruchus maculatus F. (Coleoptera: Bruchidae) também pode ser utilizado como hospedeiro alternativo de C. grandis, o parasitoide que predominantemente parasita larvas do bicudo-do-algodoeiro em campo.

Thomazini; Soares (1993) coletaram 88 exemplares de duas espécies de parasitoides associadas a larvas de $A$. grandis, 
sendo 34 indivíduos C. grandis e 54 de B. mellitor. De acordo com esses autores, os parasitoides começam a aparecer aos 77 dias após a emergência do algodoeiro, para B. mellitor houve tendência de crescimento ao longo do desenvolvimento da cultura, enquanto que para C. grandis ocorreu um pico populacional seguido de queda no número de indivíduos chegando a zero no final das amostragens.

CARVAlHo etal. (1993) relataram B. vulgaris como um potencial parasitoide para o controle do bicudo-do-algodoeiro, apresentando índices de parasitismo de $85 \%$ para estruturas das plantas e $66,6 \%$ para estruturas no solo. Enquanto Nunes; Fernandes (2000) verificaram um maior índice de parasitismo nos botôes florais coletados no solo e identificaram os parasitoides como Chelonus sp. (Microchelonus), Bracon sp. e Pteromalidae.

Carvalho; Santos (1997) observaram que ocorre um baixo índice de parasitismo (13,7\%) de $A$. grandis por $B$. vulgaris quando a produção de frutos em plantas de algodão é baixa. A localização das larvas de $A$. grandis nas estruturas dos terços superior, médio ou inferior das plantas de algodáo não influenciou na porcentagem de parasitismo pelo parasitoide $B$. vulgaris durante o ciclo (Carvalho; Santos, 1998).

ARAújo et al. (1993c) verificaram que os parasitoides B. mellitor apresentaram alta habilidade de procura às larvas de bicudo, tanto em películas de parafina como em botóes florais, mas mostraram comportamentos diferentes com relação à preferência para oviposição em estádios imaturos do bicudo. Películas de filmes de PVC podem ser utilizadas como botáo floral artificial para que larvas do bicudo-do-algodoeiro sejam submetidas ao parasitismo em laboratório para criação massal. AQuino et al. (1993) citaram a película Waxfilm ${ }^{\circledR}$ como uma alternativa mais acessível e tão eficiente quanto o Parafilm $\mathrm{M}^{\circledR}$. Além dessas, Oliveira et al. (2003) estudaram outras películas e concluíram que

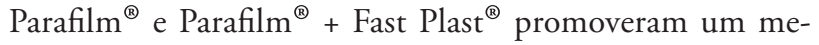
lhor desempenho na reprodução do parasitoide $C$. grandis do que as películas Fast Plast ${ }^{\circledR}$, Plast Filme ${ }^{\circledR}$ e Filmito ${ }^{\circledR}$. Os filmes Fast Plast ${ }^{\circledR}$, Plast Filme ${ }^{\circledast}$ e Filmito ${ }^{\circledR}$ reduziram o número de fêmeas que ovipositaram, o número de ovos e o número de adultos emergidos por fêmea, não afetando o tempo de desenvolvimento da fase imatura (ovo-emergência de adultos).

Resultados de Ramalho et al. (2006) mostraram a eficiência de parasitismo de C. grandis sobre o bicudo em campos onde foram liberadas fêmeas do parasitoide. A porcentagem de sobrevivência do bicudo ficou entre 3,4 e 5,8\%, inferior à dos campos onde não foram realizadas liberaçôes (entre 54,6 e 80,0\% de sobrevivência).

Ramalho et al. (2011) recomendaram que, em programas de controle biológico do bicudo-do-algodoeiro, em liberaçóes inoculativas, deve-se utilizar fêmeas adultas de B. vulgaris com aproximadamente 5 dias (a 25 ou $30^{\circ} \mathrm{C}$ ) ou 20 dias de idade $\left(\mathrm{a} 20^{\circ} \mathrm{C}\right)$; ao usar liberaçóes inundativas, utilizar fêmeas adultas de $B$. vulgaris, com idade entre 11 e 31 dias (a $\left.20^{\circ} \mathrm{C}\right)$; 9 e 29 dias (a $25^{\circ} \mathrm{C}$ ) ou 3 e 14 dias (a $30^{\circ} \mathrm{C}$ ).

$\mathrm{O}$ primeiro registro de parasitismo em adultos de A. grandis, no Brasil, por Hyalomyodes brasiliensis (Diptera: Tachinidae), foi de Pierozzi Jr.; НавiB (1986).

\section{Predadores}

Pierozzi Jr. et al. (1984) relataram a predação de A. grandis por aranhas (não identificadas) e formigas do gênero Solenopsis (Навib et al., 1984b; Gravena, 2001). Além de Solenopsis, as formigas dos gêneros Pheidole e Crematogaster foram relatadas como predadoras do bicudo-do-algodoeiro (RAMALHO et al., 1993b).

Lemos et al. (1998a, 1998b, 1999) relataram que a tesourinha Euborellia annulipes Lucas (Dermaptera: Anisolabididae) é um agente controlador de populaçōes do bicudo-do-algodoeiro, alimentando-se de larvas e pupas desse inseto. Em programas de controle biológico aplicado de $A$. grandis, as fêmeas de $E$. annulipes devem ser utilizadas quando estiverem com aproximadamente 21 dias de idade (MedeIros et al., 1998), e preferivelmente sob temperatura de $30^{\circ} \mathrm{C}$ (Lemos et al., 1998a), o que aumentará a capacidade reprodutiva desse predador. Segundo Lemos et al. (1999), a taxa de desenvolvimento das ninfas que darão origem a fêmeas apresenta-se linear e positivamente relacionada com temperatura, dentro do limite de 20 a $30^{\circ} \mathrm{C}$, enquanto que para machos as taxas desse intervalo se mantém entre 20 e $33^{\circ} \mathrm{C}$.

\section{Patógenos}

No Brasil, os fungos Beauveria bassiana (Bals.) Vuillemin e Metarhizium anispliae (Metsch.) destacam-se como agentes de controle biológico com potencial para serem empregados no controle de populaçóes de adultos do bicudo, sendo altamente patogênicos a esse inseto em laboratório e em campo (CAmargo et al., 1984; Camargo et al., 1985; Coutinho; Cavalcanti, 1988; Silva et al., 2003a). Conforme Silva (2001), o desenvolvimento externo do fungo B. bassiana no adulto do bicudo inicia entre as articulaçóes do fêmur e da tíbia, membrana cervical e suturas cranianas, recobrindo posteriormente todo o corpo do hospedeiro.

ANDRADE et al. (1984) relataram a ocorrência de doenças bacteriana, viral e micótica em populaçôes de $A$. grandis na região de Campinas, São Paulo. A bactéria Serratia marcences Bizio ocorreu de forma epizoótica, causando mortalidade de mais de $50 \%$ de larvas e pupas coletadas. Entomopoxvirus, causador da esferoidose, foi responsável por causar alto índice de mortalidade em larvas e pupas. E uma doença causada por fungo, provavelmente do gênero Isaria, foi observada em larvas e adultos.

CAMARgo et al. (1984) isolaram uma cepa natural do fungo Beauveria sp. que infectava o bicudo-do-algodoeiro na 
regiáo de Campinas, São Paulo. Esta se mostrou patogênica em laboratório, alcançando índice de infectividade acima de $50 \%$. Em estudos sobre a susceptibilidade do bicudo aos fungos B. bassiana e M. anisopliae, CAMARgo et al. (1985) observaram que ambos foram altamente patogênicos ao bicudo, resultando na mortalidade de $100 \%$ dos curculionídeos, após sete dias de inoculação. Esses autores ressaltaram também que o aumento da umidade acelerou o processo infeccioso e que o fungo $M$. anisopliae apresentou ação mais rápida do que $B$. bassiana nos três primeiros dias após a inoculação. Oliveira et al. (1994) relataram que o bicudo também é susceptível a mutantes morfológicos e tipos selvagens de $M$. anisopliae var. majus e $M$. anisopliae minus.

Alves et al. (1986) estudaram a suscetibilidade de A. grandis ao fungo B. bassiana isolado 61 nas dosagens $10^{6}$, $10^{7}$ e $10^{8}$ conídios viáveis $/ \mathrm{mL}$ do patógeno e determinaram, utilizando um programa computacional de análise de próbite, os tempos letais de $50 \%\left(\mathrm{TL}_{50}\right)$ de 33,9; 25,1 e 13,5 dias, respectivamente, para as doses $10^{6}, 10^{7}$ e $10^{8}$ conídios viáveis $/ \mathrm{mL}$. Para 12 e 24 dias, as doses letais de $50 \%\left(\mathrm{DL}_{50}\right)$ foram de $1,9 \times 10^{11}$ e $5 \times 10^{10}$ conídios $/ \mathrm{mL}$. Coutinho; Cavalvanti (1988) observaram que o índice de infectividade do bicudo por $B$. bassiana foi de $87,83 \%$ e o período médio para infecção foi de 6 dias.

Jaramillo; Alves (1986), utilizando as mesmas dosagens que Alves et al. (1986) para o fungo M. anisopliae isolado SPL-255, determinaram uma $\mathrm{DL}_{50}$ após 12 dias igual a 7,6 x $10^{6}$ conídios viáveis $/ \mathrm{mL}$. Para $10^{6}, 10^{7}$ e $10^{8}$ conídios viáveis $/ \mathrm{mL}$, os $\mathrm{TLs}_{50}$ foram respectivamente 22,4 ; 11,3 e 6,3 dias.

Coutinho; Oliveira (1989), testando o isolado $\mathrm{I}-1149 \mathrm{Bb}$ de $B$. bassiana, observaram que a concentração $3,72 \times 10^{10}$ conídios $/ \mathrm{mL}$ foi a mais eficiente e apresentou a maior concentração de conídios sobre cadáveres do bicudo-do-algodoeiro, já as concentraçôes letais de $50 \%\left(\mathrm{CL}_{50}\right)$ apresentaram valores de $2,59 \times 10^{10} \mathrm{e} 1,30 \times 10^{7}$ conídios $/ \mathrm{mL}$ aos 7 e 14 dias, respectivamente.

Silva (2001) destacou que isolados de B. bassiana de diferentes hospedeiros e regiôes geográficas são diferentes quanto à virulência ao bicudo-do-algodoeiro. $\mathrm{O}$ autor testou 12 isolados do fungo provenientes de micotecas de diversas instituiçôes e observou que a mortalidade do bicudo teve início no segundo dia após a inoculação das suspensôes fúngicas, variando de 15 a $83 \%$, sendo os isolados CG138, CNPA02, CNPA03, CG082, CNPA1 e CG070 mais virulentos do que aos isolados 645, CG458, CNPA04, CG016 e 760. Esse autor ressaltou ainda que o isolado CG138 destacou-se como um dos mais virulentos e que os isolados 645, 760 e CG458, obtidos originalmente de $A$. grandis, foram pouco virulentos a esse inseto. Thomazoni et al. (2005) também compararam isolados provenientes de diferentes hospedeiros e regiôes geográficas do Brasil, sendo 24 da espécie $B$. bassiana e 4 da espécie $M$. anisopliae, e verificaram que os isolados de $M$. anisopliae foram mais patogênicos do que os de $B$. bassiana e que a mortalidade confirmada teve início no segundo dia após a exposição aos conídios.

Almeida et al. (2005) verificaram que $B$. bassiana (URM-3447), reisolado de ovos, larvas e adultos de A. grandis, possui elevado potencial de controle desse inseto, apresentando elevada viabilidade de germinaçáo, crescimento colonial e conidiogênese em meio de cultura batata-dextrose-ágar (BDA). GonçALves et al. (2005), avaliando cepas de fungo B. bassiana, concluíram que as diluiçóes de $2,5 \mathrm{~g} / 500 \mathrm{~mL} \mathrm{e}$ $10 \mathrm{~g} / 500 \mathrm{~mL}$ de água destilada apresentaram baixa capacidade de infecção ao inseto. Giometтr et al. (2006) avaliaram os isolados IBCB 18, 35 e 66, e GiometTi et al. (2010), além desses três, avaliaram também os isolados IBCB $82,87,238$, 239, 240 e 241 de B. bassiana e concluíram que todos os isolados testados foram patogênicos ao bicudo-do-algodoeiro, causando entre 50 e $85 \%$ de mortalidade, sendo o isolado IBCB 241 considerado o mais virulento, apresentando a maior percentagem de mortalidade e a menor $\mathrm{TL}_{50}$, seguido pelo isolado IBCB 87. Coutinho; Oliveira (1991), avaliando a patogenicidade do isolado I-149Bb de B. bassiana, obtiveram mortalidade variando de 50 a $100 \%$ nas concentraçóes entre $3,72 \times 10^{6}$ a $3,72 \times 10^{10}$ conídios $/ \mathrm{mL}$.

De acordo com PraÇa et al. (2004), as estirpes S234 e S997 de B. thuringiensis foram efetivas contra larvas de $A$. grandis quando a cultura bacteriana foi incorporada à dieta artificial oferecida ao inseto. Dumas et al. (2006) relataram que três estirpes patogênicas ao bicudo pertencentes ao banco de Bacillus spp., da Embrapa Recursos Genéticos e Biotecnologia, se destacaram pelos resultados de $\mathrm{CL}_{50}$ e pelos perfis proteicos e moleculares bastante semelhantes, apresentando uma banda de $130 \mathrm{kDa}$ e genes da família Cryl, indicando serem fortes candidatos para estudos moleculares e integraçáo no genoma de cultivares de algodáo como alternativa para o controle desse inseto.

Bleicher et al. (1994) concluíram que o fungo B. bassiana associado a um décimo da dosagem do inseticida deltamethrin (1 g.i.a./ha) foi tão eficiente quanto o inseticida na sua dosagem normal para o controle do bicudo.

Nas condiçóes de laboratório, segundo Gutierrez (1986), B. bassiana alongou o período de pré-oviposição e diminuiu o período de oviposição e o número de ovos/fêmea. A fertilidade dos ovos colocados por fêmeas infectadas pelo fungo não foi afetada. As fêmeas morreram em tempo mais curto do que os machos. Nas condiçóes de campo, o fungo causou uma mortalidade máxima de 28,8\% nos adultos presentes. Entretanto, o adulto, antes de morrer, ocasionou grandes danos às estruturas frutíferas da planta. SiLVA et al. (2003), avaliando o potencial do fungo B. bassiana associado ao tubo mata bicudo (TMB), também em condiçôes de campo, observaram seu efeito positivo no controle da praga, reduzindo a porcentagem de botôes florais danificados em comparaçáo com a testemunha. 
Visando determinar a proporçáo mais adequada dos veículos da suspensão de conídios de $B$. bassiana pulverizados no controle do bicudo, SiLva et al. (2003b) testaram pulverizaçôes com conídios do fungo suspensos em nove combinaçôes de diferentes concentraçôes de óleo vegetal e querosene. Esses autores relataram que as melhores formulaçóes foram aquelas nas quais os conídios de $B$. bassiana foram suspensos em: pulverização com óleo vegetal a $95 \%$ + querosene a $5 \%$ ou pulverizaçáo com óleo vegetal a $70 \%$ + querosene a $30 \%$, cujos rendimentos de produção foram maiores, sendo as médias de rendimento da cultivar de 810,25 e $760,00 \mathrm{~g}$, respectivamente.

\section{Prospecção de produtos naturais}

Fernandes et al. $(1993,1996)$ concluíram que os extratos de Melia azedarach (cinamo), Crocus sativus (açafrão) e Piper nigrum (pimenta do reino) apresentaram índices satisfatórios de inibiçáo alimentar contra o bicudo. Conforme Fernandes et al. (1996), o extrato aquoso de P. nigrum apresentou o maior índice de inibição alimentar $(100 \%)$ e além de causar o efeito deterrente, esse extrato causou mortalidade de $26,7 \%$ dos bicudos adultos. Esses autores relataram ainda que o extrato $C$. sativus causou mortalidade entre 10 e 16,7\% dos indivíduos; o extrato de M. azedarach não causou mortalidade após $48 \mathrm{~h}$ de exposição. Resultado que também foi encontrado por GABRIEL; Beltramelli (2005), que observaram que o Nim utilizado tanto na formulaçáo torta quanto em óleo emulsionado não inibiu a alimentação e não promoveu a mortalidade do bicudo do algodoeiro. Fernandes et al. (1996) testaram também o extrato de Chenopodium ambrosioides (erva-de-santa-maria) e observaram que ele apresentou índices de inibição alimentar muito baixo e não causou mortalidade dos bicudos.

O mais novo método alternativo utilizado para controle do bicudo é o caolim. De acordo com estudos de SiLVA (2011), o caolim exerce um efeito controlador sobre o bicudo-do-algodoeiro, pelo seu efeito deterrente sobre o comportamento de oviposiçáo do bicudo, impedindo seu contato visual e táctil com a planta hospedeira, tornando-a irreconhecível e atrapalhando sua movimentação e a alimentação pela adesão de partículas no seu corpo. Os resultados de Sinva et al. (2009b) mostraram que o caolim aplicado tanto de forma sistemática e/ou sempre que o bicudo atinge o nível de controle é capaz de proteger os botôes florais do algodoeiro da injúria provocada pelo bicudo, com eficiência semelhante ao inseticida endosulfan. De acordo com Silva et al. (2009a), pulverizaçôes com caolim, caolim $+B$. bassiana e $B$. bassiana apresentam maior produção do que a testemunha (sem tratamento), indicando que esses produtos podem ser utilizados no controle do bicudo.

\section{Controle legislativo}

Bianchini (2004) relata que, visando reduzir o ataque de populaçôes de bicudo em safras seguintes, a prática cultural de eliminaçáo da soqueira do algodáo se tornou obrigatória no Brasil, estando por meio de portaria ministerial a incumbência de definir as datas limites para a permanência das soqueiras no campo. Carvalho (2001) relatou que nos estados de São Paulo, Paraná, Bahia e Ceará a destruição da soqueira se tornou obrigatória por lei, sendo que a data limite para cada estado leva em consideração o comportamento da praga. BAstos; Almeida (2005) relataram que a legislação federal prevê que a destruiçáo de soqueiras seja feita até no máximo 31 de agosto de cada ano agrícola, tanto em áreas infestadas quanto em áreas indenes. Porém, de acordo com esses autores, a aplicabilidade dessa medida é restrita, pois em algumas regiôes onde se realiza o cultivo sucessivo essa medida é contestada.

Segundo Bianchini (2004), no estado do Mato Grosso os cotonicultores têm até o dia 31 de agosto para destruir as soqueiras de suas lavouras. Outra medida criada neste estado para interromper o ciclo do bicudo foi a adoção de um calendário para plantio. Em áreas produtoras de algodão infestadas pelo bicudo, a Portaria no 29 , de 25 março de 2002, do Instituto de Defesa Agropecuária do Mato Grosso (INDEA) sugeriu que o plantio de algodão fosse realizado entre 20 de novembro e 02 de janeiro (Bastos; Almeida, 2005). Posteriormente, através da Instrução Normativa Conjunta 001/2007, que dispóe sobre as medidas fitossanitárias para prevençáo do bicudo no Mato Grosso, foi definido que o plantio deveria ser realizado de $1^{\circ}$ de dezembro e 10 de fevereiro, adotando-se um período de 75 dias de vazio sanitário, entre 15 de setembro e 30 de novembro, visando interromper o ciclo de vida do inseto (CASSETARI Neto et al., 2008).

\section{Manejo integrado}

НАBiB et al. (1984b) adaptaram um projeto de manejo que envolveu a utilização de plantas iscas e outras práticas culturais, armadilhas de feromônio e o uso de inseticidas seletivos gerando maior produtividade e economia nos custos de produção da área em relação ao manejo convencional.

Os resultados de SoAres (1998) são favoráveis à aplicação de táticas como controle químico, eliminação das gemas apicais (poda), capação do algodoeiro com diferentes idades e aplicação de cloreto de mepiquat para o manejo integrado de $A$. grandis em algodoeiro. Soares et al. (2002) validaram um sistema de MIP do algodoeiro onde $A$. grandis estava entre as principais pragas, concluindo que é possível produzir algodão no Cerrado baiano, com 6 pulverizaçóes e com uma reduçáo de custos de $50 \%$ com inseticidas.

Segundo Degrande et al. (2001), no Oeste do estado da Bahia, durante a safra 2000/2001, a implantação de 
uma estratégia regional de controle do bicudo conseguiu uma efetiva redução populacional da praga e uma economia conjunta de US\$ 2 milhóes que seriam utilizados em produtos para pulverizaçóes. Essa estratégia conjunta de produtores para bloqueio ao bicudo se baseou em táticas de manejo como aplicaçóes de inseticidas no final do ciclo da cultura, cumprimento da legislação quanto à destruição da soqueira e período mínimo de 4 meses sem plantio de algodão, época de semeadura concentrada em 40 dias, tratamento rigoroso da bordadura e aplicação de inseticidas no início da emissão dos botôes florais.

Pierozzi Jr.; Наbib (1992, 1993c) apresentaram propostas de programa de MIP para algodoais infestados pelo bicudo na regiáo de Campinas e Sudeste do estado de São Paulo. Nelas são consideradas diversas táticas de manejo, como a época e o período de plantio, variedade de algodoeiro, utilização de plantas iscas, feromônio como bloqueio e associado ao sistema de armadilha, técnicas de monitoramento da cultura e de aplicação de inseticidas químicos seletivos, técnica de redução de número de adultos no período final da cultura, uso de produtos desfolhantes e de soqueiras iscas e destruição dos restos da lavoura imediatamente após a colheita.

Degrande (1993) validou um programa de MIP no estado de Mato Grosso do Sul. A tecnologia de MIP foi baseada em época de semeadura, plantio-isca, variedade, espaçamento e altura das plantas, catação de botóes florais e maçãs caídas, amostragens, níveis de controle, controle químico, uso de desfolhante, colheita, destruição de soqueiras, soqueira-isca, adequação de propriedades físicas, químicas e conservação do solo, controle biológico, feromônios, rotação de culturas e outras táticas complementares. $\mathrm{Na}$ validação, o número de aplicaçóes de inseticidas, em áreas com $A$. grandis, caiu de 6,5, média dos produtores da região, para 4,7 em áreas onde se utilizou o programa de MIP.

NAKANo et al. (1993) relataram que o fitoregulador cloreto de dimetil piperidina concentrou a produtividade, expondo os órgãos florais e frutíferos por um período menor ao ataque do bicudo, resultando em maior número de maçãs. De acordo com Pípolo et al. (1998), a aplicação do regulador de crescimento cloreto de clorocolina, apesar de causar maior precocidade e redução do número de maçãs imaturas, não foi suficiente para provocar um efetivo controle do bicudo isoladamente.

Pessoa et al. (1993a) relataram uma proposta de modelagem matemática para a dinâmica populacional do bicudo, levando-se em consideraçáo medidas de MIP para a região analisada e permitindo o monitoramento das populaçóes do inseto, viabilizando através de simulação a avaliação do comportamento populacional do inseto frente à utilizaçáo de medidas de controle biológico baseadas na utilização de inimigos naturais.
Ramalho; Gonzaga (1989b, 1990) concluíram que o consórcio algodão com milho não afeta a população do bicudo-do-algodoeiro. BiAnCHINI (2004) recomendou uma maneira de manter baixo o nível das populaçóes, através da utilização de armadilhas com feromônio e a eliminação das plantas hospedeiras e soqueiras que podem servir de abrigo e alimento para o inseto.

Moreira et al. (2004) sugeriram o controle climático (deficiência hídrica do período experimental aliada a altas temperaturas típicas da região) no Seridó paraibano como responsável pelos baixos níveis populacionais do bicudo-do-algodoeiro. Coutinho; Calvancanti (1988) concluíram que a utilização de substrato fúngico no interior das câmaras de captura das armadilhas de feromônio não interferiu na captura dos curculionídeos.

$\mathrm{Na}$ região dos Chapadões, segundo TomQuelski; Martins (2008), foi montado um consórcio antibicudo, baseado no proposto por Degrande et al. (2003, 2004) para o estado de Goiás, para atender a região do norte do Mato Grosso do Sul, o consórcio que se baseou em medidas como armadilhamento pré-safra, destruição de tigueras, instalação de tubos atrai-e-mata, semeadura concentrada, aplicação de bordadura, aplicação de primeiro botão-floral e de final de ciclo, além de boas práticas de transporte que promoveram diminuição na infestação, o que provocou atraso ou mesmo diminuição do número de indivíduos infestando as lavouras e, consequentemente, contribuiu para redução do número de aplicaçóes de inseticidas.

\section{Programas de supressão}

No Brasil, são cogitadas iniciativas em programas de erradicação do bicudo que consistem na implantação de medidas fitossanitárias para eliminação da praga alvo (Silva, 2012), porém nunca foi implantado um Programa de Erradicação no País, nem mesmo num modelo experimental ou piloto com as devidas confirmaçóes da Ciência ou da Extensão. Segundo Silva (2012), o termo mais adequado e que vem dando resultados é a supressão, que consiste na aplicação de um conjunto de medidas fitossanitárias visando diminuir a população de uma praga em todas as fases da cultura em uma determinada área infestada, e inclusive no período de entressafra. Alguns estados brasileiros como Bahia, Goiás, Mato Grosso e São Paulo vêm adotando ações estadualizadas por meio de medidas fitossanitárias baseadas no MIP para supressão desse inseto (Degrande et al., 2004; Degrande, 2006; Silva et al., 2012; Lima Jr. et al., 2013). Degrande et al. (2001) e Degrande (2002) ressaltaram que, devido às características do bicudo, o sucesso desses programas de manejo depende da adoção de atitudes coletivas na região de ocorrência da praga, evitando assim surtos populacionais regionais do inseto. 
O estado brasileiro pioneiro na adoçáo de um programa de controle do bicudo foi Goiás, no qual o programa foi responsável pelo aumento da produtividade registrado na maioria das lavouras (Degrande et al., 2004). De acordo com Degrande et al. (2003), o Plano Estratégico de Controle do Bicudo-do-algodoeiro no estado de Goiás, criado na safra 2002/2003 com a meta principal de reduzir a população do bicudo nas regióes produtoras de algodão do estado, baseou-se em várias táticas de manejo, como semeadura concentrada num período de 30 a 40 dias, aplicação de inseticidas na bordadura a partir do estágio V2, 3 aplicaçóes de inseticidas a partir do surgimento dos primeiros botôes florais, monitoramento constante da lavoura, adoçáo de nível de controle de 5\% de botóes florais atacados, 3 aplicaçôes de inseticidas quando for identificado o primeiro capulho aberto e destruição das soqueiras até no máximo 15 dias, introdução de culturas-iscas, catação manual de maçás e botôes caídos, escolha de variedades precoces e aplicação de inseticida no final da safra. Segundo Degrande et al. (2003), esse plano, quando adotado na íntegra, apresentou bons resultados como aumento na produção entre 2,5 e $23 \%$ em relação à safra anterior. Assim, novas táticas com o armadilhamento e mapeamento das lavouras visando indicar o nível de infestação e aumentar a produtividade foram sugeridas para as próximas etapas do plano.

Em várias regiōes de Goiás, dentre elas Itumbiara, Buriti Alegre, Morrinhos, Goiatuba, Cachoeira Dourada (Oliveira et al., 2005), Acreúna (Santos et al., 2005), Inaciolândia (Pires et al., 2005), Mineiros (Silva et al., 2005a), Paraúna (Silva et al., 2005b), Santa Helena (Silva et al., 2005c, 2005d), Ipameri (Silva et al., 2005e, 2005f), Luziânia, Silvânia, Cristalina (Degrande et al., 2009; Lima Junior et al., 2013) e Perolândia (Rezende et al., 2011), a adoção de todas as açôes do plano de supressão proporcionam resultados satisfatórios, como reduçáo do número de aplicaçôes para bicudo, atraso do inseto nas lavouras, produção de capulhos na parte apical das plantas ("ponteiros"), com consecutivo ganho na produção e produtividade e menores quantidades de inseticidas aplicadas no meio ambiente. GARCIA et al. (2009) observaram que em área onde o plano não foi executado totalmente houve aumento no número de pulverizaçôes para o controle químico do bicudo de uma safra para outra, resultando em menor retorno econômico ao produtor e maior impacto ambiental.

Para o estado de Goiás, Oliveira et al. (2011) citaram também o Projeto de Supressão do Bicudo do Algodoeiro de Goiás, que teve o intuito de reduzir o nível populacional do inseto a índices abaixo do nível de dano econômico. Segundo esses autores, os quatro primeiros anos de implantação desse projeto, no Vale do Pamplona e no município de Silvânia, mostraram reduçáo generalizada da população do inseto com consequente redução da necessidade do controle químico e náo comprometimento da produtividade pelo inseto.
No Oeste da Bahia, o programa de supressão do bicudo, de acordo com BRUGNerA (2009), está baseado em açóes regionais envolvendo as propriedades de uma determinada comunidade. Ele recomenda a destruiçáo da soqueira imediatamente após a colheita (prazo máximo até 31 de agosto para a regiāo); armadilhamento nas bordaduras 60 dias antes do início do plantio; plantio concentrado em um período curto; controle químico nas bordaduras no início da segunda folha verdadeira; aplicações de inseticidas na emissão dos botôes; controle com índices inferiores a 5\% de botôes atacados; aplicaçáo de inseticidas juntamente com desfolhante, além de outras açôes complementares. Nessa mesma regiáo, segundo Tamai et al. (2009), o Programa de Monitoramento e Controle do Bicudo no Oeste da Bahia representa uma ferramenta importante para a sustentabilidade da cultura. Com ele houve uma importante modificação na forma de condução dos trabalhos, com a criação e validação dos "Núcleos Regionais de Controle do Bicudo", através da integração dos produtores, pertencentes à mesma sub-regiáo, em açôes coletivas de controle do bicudo.

\section{Transgenia no Brasil}

A transgenia é um dos métodos estudados, ainda de forma experimental, no Brasil, visando à redução populacional do bicudo-do-algodoeiro. Franco et al. (2000) observaram que larvas e adultos do bicudo alimentados com dieta artificial contendo o inibidor kunitz tripsina da soja (SKTI) apresentaram redução no peso e comprimento (larvas), deformaçóes e ausência de tórax (pupas e insetos adultos). Dias et al. (2004) relataram que outro inibidor proteico, a A-amilase/tripsina isolada de plantas de centeio (Secale cereale), causou reduçáo do peso larval em até $42 \%$ e um aumento de $83 \%$ na mortalidade para concentraçáo ( $0,8 \%$ peso/volume). Del Sarto et al. (2005) selecionaram $\alpha$-amilases variantes, isoladas de sementes de Phaseolus vulgaris, inibidoras de enzimas hidrolíticas específicas contra as $\alpha$-amilases de $A$. grandis.

Os resultados de Santos et al. (2002) demonstraram a influência da enzima colesterol oxidase (Coase) sobre A. grandis. Larvas que foram alimentadas com dieta artificial contendo diferentes concentrações da enzima tiveram sua sobrevivência afetada e apresentaram regióes altamente vacuolizadas nas células epiteliais, bem como degradação parcial das membranas basal e microvilli. A enzima também interferiu na eclosão das larvas quando os ovos foram submersos por 15 minutos em solução de Coase. Santos (2004), em testes, observou que essa proteína promoveu retardo do crescimento e morte das larvas, redução na eclosão e na postura das fêmeas, além de causar danos nos insetos desde o seu desenvolvimento embrionário.

SÁ et al. (2004) relataram que os novos genes cryEa e cry $3 a$ apresentam toxicidade para larvas do bicudo-do-algodoeiro e 
potencial de aplicação em programa de melhoramento genético de algodão, via transgenia, para o controle desse coleóptero. Em seus estudos, BRunETTA et al. (2005) observaram que 21 genes mutantes de cry $3 A a$ e $c r y 8 G a$ de $B t$ causaram variabilidade na taxa de mortalidade das larvas do bicudo. MarTins et al. (2010) foram os autores do primeiro relato sobre a localização da ligação entre toxina $\mathrm{Bt}$ Cry e receptores em células do intestino médio de $A$. grandis. Segundo esses autores, a toxina se ligou a duas proteínas (62 e $65 \mathrm{kDa}$ ), que apresentaram atividade de fosfatase alcalina (ALP), sendo esses resultados importantes para a melhor compreensão do modo de ação dessa toxina.

Artico et al. (2009), visando ao desenvolvimento de novas ferramentas biotecnológicas para o controle mais efetivo do bicudo-do-algodoeiro, identificaram nove genes com expressão predominante em flores e mais especificamente em estames de algodoeiro. Os quatro genes selecionados nesse estudo foram considerados fortes candidatos ao isolamento de promotores e dois desses genes tiveram as regióes promotoras isoladas e a análise preliminar confirmou a presença de elementos regulatórios típicos da expressão em pólen.

Coelho et al. (2010) isolaram os fragmentos gênicos da glicoproteína vitelogenina $(\mathrm{Vtg})$ e do receptor de ecdisona (EcR) de $A$. grandis e clonaram no vetor de expressão em bactéria pL4440gtwy e transferiram para cepa de Escherichia coli HT115 para a produçâo de dsRNA, para posterior clonagem e síntese dos fragmentos para realização futura de bioensaios de silenciamento gênico visando ao controle do inseto.

De acordo com Ferreira Filho; Gameiro (2002), o algodáo geneticamente modificado com a tecnologia Bollgard $^{\circledR}$ no Brasil, efetiva no controle de lagartas, resultou em uma importante reduçáo nos custos de produção, porém em regióes onde o bicudo-do-algodoeiro era uma praga importante foi observada uma menor redução desses custos.

Degrande; Fernandes (2006) relataram que o algodáo $\mathrm{Bt}$, por ser menos pulverizado do que o algodão não $\mathrm{Bt}$, acarreta o crescimento da populaçáo de bicudos e de outras pragas nas lavouras de algodoeiro náo alvo da tecnologia. Milane et al. (2008) e Gabriel et al. (2009) não observaram diferença significativa entre o algodoeiro geneticamente modificado $\mathrm{Bt}$ (NuOpal) e o convencional (DeltaOpal) quanto ao percentual de ataque do bicudo por planta, número total de estruturas atacadas em cada parcela, número de estruturas reprodutivas disponíveis na planta e número de bicudos emergidos em laboratório. Grigolli et al. (2011), também comparando esses cultivares, observaram que os picos maiores de alimentação e oviposição ocorreram aos 104 e 101 DAE (dias após a emergência), nos cultivares DeltaOpal e $\mathrm{NuOpal}$, respectivamente. $\mathrm{O}$ que demonstra a necessidade de controle do bicudo nos cultivares transgênicos da mesma forma que nos convencionais (GABRIEL et al., 2009).

\section{CONSIDERAÇÕES FINAIS}

Após a detecção do bicudo-do-algodoeiro no Brasil, em 1983, esse inseto passou a ser objeto de vários estudos no país, desde aqueles básicos de biologia aos estudos avançados de transgenia de plantas. Nesse repertório de pesquisas estão incluídos trabalhos de detecção regional, fisiologia, ecologia, etologia, distribuição geográfica (mapeamento), plantas hospedeiras, dinâmica populacional, prejuízo e dano econômico, amostragem, nível de controle, controle comportamental, cultural e alternativo aos inseticidas químicos, resistência de planta, controle biológico e microbiano, prospecçâo de produtos naturais, controle legislativo, iniciativas de planos de supressão e adequação ao MIP. Há ainda uma série de estudos de controle químico, os quais não foram contemplados nesta revisão bibliográfica propositalmente.

A presença do bicudo-do-algodoeiro no Brasil contribuiu para a mudança dos polos de produção de algodáo no território nacional ao longo desses 30 anos, em especial com o deslocamento do cultivo da fibrosa do Nordeste e Sudeste para as áreas do Cerrado brasileiro, numa espécie de busca de locais menos infestados visando alguma diminuição dos custos de produção. No caso da agricultura familiar, ficou evidente a dificuldade de construir modelos de manejo viáveis com reduzido uso de inseticidas, na prática, enquanto que na agricultura empresarial há modelos mais sustentáveis sob o ponto de vista de racionalidade econômica na atualidade.

A erradicaçáo de $A$. grandis do Brasil, à semelhança do que foi feito nos Estados Unidos da América, tem sido objeto de dúvida, face à diversidade de ecossistemas, dimensôes geográficas do país e à facilidade de sobrevivência da praga na entressafra. Assim, nos últimos anos, observa-se a busca por estratégias e táticas para reduzir o nível populacional do inseto a índices inferiores ao do nível de dano econômico, em todas as fases da cultura em uma determinada área infestada, e inclusive no período de entressafra, através da utilização de um conjunto de medidas fitossanitárias preconizadas pelo MIP ou modelo de supressão populacional. Paralelamente, há nos dias de hoje iniciativas por métodos de redução populacional da praga com uso de transgenia, ainda de forma experimental. Em síntese, mais pesquisas precisam ser desenvolvidas no país, na busca de novos e alternativos métodos de controle ao bicudo-do-algodoeiro que considerem as particularidades regionais. 


\section{REFERÊNCIAS}

ALMEIDA, J.C.; ALBUQUERQUE, A.C.; LUNA-ALVES LIMA, E.A. Viabilidade de Beauveria bassiana (Bals.) Vuill. reisolado de ovos, larvas e adultos de Anthonomus grandis (Boheman) (Coleoptera: Curculionidae) artificialmente infectado. Arquivos do Instituto Biológico, São Paulo, v.72, n.4, p.473-480, 2005.

ALMEIDA, R.P.; SOARES, J.J.; SOUTO, S.R.M.; OLIVEIRA, J.B. Resposta de plantas de algodão ao ataque do bicudo Anthonomus grandis. In: CONGRESSO BRASILEIRO DE ENTOMOLOGIA, 16., 1997, Salvador, BA. Resumos. Salvador: SEB/Embrapa-CNPMF, 1997. p.205.

ALVES, S.B.; JARAMILLO, C.B.J.; SILVEIRA NETO, S. Patogenicidade da Beauveria bassiana (Bals.) Vuill. isolado 61 ao bicudo-do-algodoeiro Anthonomus grandis Boheman. In: CONGRESSO BRASILEIRO DE ENTOMOLOGIA, 10., 1986, Rio de Janeiro, RJ. Resumos. Londrina: SEB, 1986. p.186.

AMBROGI, B.G.; VIDAL, D.M.; ZARBIN, P.H.G.; ROSADO-NETO, G.H. Feromônios de agregação em Curculionidae (Insecta: Coleoptera) e sua implicação taxonômica. Química. Nova, São Paulo, v.32, v.8, p.2151-2158, 2009

ANDRADE, C.F.S.; PIEROZZI JR., I.; HABIB, M.E.M. Ocorrência natural de doenças infecciosas em populações do "bicudo", Anthonomus grandis BOHEMAN, 1843. In: CONGRESSO BRASILEIRO DE ENTOMOLOGIA, 9., 1984. Londrina, PR. Resumos. Londrina: SEB, 1984. p.154.

AQUINO, I.S.; RAMALHO, F.S.; JESUS, F.M.M.; GUEVARA, L.A.C. Eficiência de armadilhas de feromônio novas e usadas na captura do bicudo-do-algodoeiro. Pesquisa Agropecuária Brasileira, Brasília, v.21, n.8, p.817-821, 1986.

AQUINO, I.S.; RAMALHO, F.S.; ARAUJO, L.H.A. Waxfilm (Pat. Dep.), uma película alternativa na criação de parasitoides. In: CONGRESSO BRASILEIRO DE ENTOMOLOGIA, 14., 1993. Piracicaba, SP. Resumos. Piracicaba: SEB, 1993. p.292.

ARAÚJO, A.A. Podridão das maçãs em algodão. Cultivar Grandes Culturas, Pelotas, n.137, p. 18-20, 2010.

ARAÚJO, A.D.; SOARES, J.J.; ARAÚJO, L.H.A. Influência da época de plantio e do ataque de bicudo Anthonomus grandis BOHEMAN 1843, (Coleoptera, Curculionidae) sobre a abscisão de botões e maçãs de algodoeiro. In: CONGRESSO BRASILEIRO DE ENTOMOLOGIA, 14., 1993a. Piracicaba, SP. Resumos. Piracicaba: SEB, 1993. p. 568.

ARAÚJO, L.H.A.; ALMEIDA, R.P.; BRAGA SOBRINHO, R.; AZEVEDO, F.R.; QUEIROZ, M.F. Aspectos bioecológicos de Bracon sp (Hymenoptera: Braconidae) uma parasitoide do bicudo do algodoeiro. In: CONGRESSO BRASILEIRO DE ENTOMOLOGIA 14., 1993b. Piracicaba, SP. Resumos. Piracicaba: 1993. p. 48.

ARAÚJO, L.H.A.; ALMEIDA, R.P.; DIAS, J.M. Tabela de esperança de vida para adultos de Bracon sp. (Hymenoptera: Braconidae) parasitoide do bicudo do algodoeiro. Scientia Agricola, Piracicaba, v.54, n.3, p.247-250, 1997.
ARAÚJO, L.H.A.; AZEVEDO, F.R. Aspectos biológicos de Catolaccus grandis (Burks) (Hymenoptera: Pteromalidae), parasitoide do bicudo do algodoeiro. Anais da Sociedade Entomológica do Brasil, Londrina, v.26, n.3, p.503-506, 1997.

ARAÚJO, L.H.A.; BRAGA SOBRINHO, R.; MESQUITA, C.K.; ALMEIDA, R.P.. Observações sobre alguns parasitoides do bicudo do algodoeiro. In: CONGRESSO BRASILEIRO DE ENTOMOLOGIA, 13., I SIMPÓSIO INTERNACIONAL SOBRE BICUDO DO ALGODOEIRO, II ENCONTRO SOBRE "COCHONILHA" DA PALMA FORRAGEIRA, III ENCONTRO SOBRE MOSCAS-DAS-FRUTAS, 1991. Recife, PE. Resumos. Londrina: SEB, 1991. p.574.

ARAÚJO, L.H.A.; BRAGA SOBRINHO, R.; QUEIROZ, M.F. Aspectos biológicos de adultos de um parasitoide do bicudo do algodoeiro. Scientia Agricola, Piracicaba, v.56, n.4, p.765768, 1999.

ARAÚJO, L.H.A.; BRAGA SOBRINHO, R.; ALMEIDA, R.P.; MESQUITA, C.K. Biological control of the boll weevil. Pesquisa Agropecuária Brasileira, Brasília, v.28, n.2, p.257-261, $1993 c$.

ARAÚJO, T.A.; FREITAS, L.M.; SOUSA, J.G.; RODRIGUES, L.V.; CAMPOS, G.E.; VIEIRA, R.A.; CRISÓSTOMO FILHO, C.V.; BASTOS, C.S. Preferência de ataque do bicudo (Anthonomus grandis) e da lagarta-rosada (Pectinophora gossypiella) por diferentes estruturas reprodutivas. In: CONGRESSO BRASILEIRO DE ENTOMOLOGIA, 23., 2010. Natal, RN. Resumos. Natal: SEB, 2010.

ARTICO, S.; NARDELI, S.M; BRILHANTE, O.; GROSSI-DEAS, M.F.; ALVES-FERREIRA, M. Desenvolvimento de novas ferramentas biotecnológicas para o controle mais efetivo do bicudo-do-algodoeiro: identificação de gene expressos predominantemente em tecidos florais de algodão e clonagem de promotores específicos de flor. In: CONGRESSO BRASILEIRO DE ALGODÃO, 7. 2009, Foz do Iguaçu, PR. Sustentabilidade da cotonicultura Brasileira e Expansão dos Mercados: Anais... Campina Grande: Embrapa Algodão, 2009. p. 285-292.

AZEVEDO, F.R.; VIEIRA, F.V. Levantamento populacional de pragas do algodoeiro em condições de sequeiro. Ciência Agronômica, v.33, n.1, p15-19, 2002.

BARBOSA, S.A. Presença do bicudo do algodoeiro no Cone Sul e seu impacto sobre a cotonicultura regional. In: CONGRESSO BRASILEIRO DE ENTOMOLOGIA, 16., 1997. Salvador, BA. Palestras. Salvador: SEB/Embrapa-CNPMF, 1997. p.31.

BASTOS, C.S.; ALMEIDA, R.P. Influência negativa do manejo no algodão. Cultivar Grandes Culturas, Pelotas, n.74, p. 10-12, 2005.

BASTOS, C.S.; PEREIRA, M.J.B.; TAKIZAWA, E.K.; OHL, G.; AQUINO, V.R.. Bicudo do algodoeiro: identificação, biologia, amostragem e táticas de controle. Campina Grande: Embrapa Algodão (Circular Técnica 79), 2005. $31 \mathrm{p}$ 
BELORTE, L.C.C; RAMIRO, Z.A. Estudo da dinâmica populacional do bicudo do algodoeiro Anthonomus grandis Boheman, 1843 (Coleoptera, Curculionidae) na DIRA de Araçatuba/SP. In: CONGRESSO BRASILEIRO DE ENTOMOLOGIA, 14., 1993. Piracicaba, SP. Resumos. Piracicaba: SEB, 1993. p.139.

BIANCHINI, A. Limpeza total. Cultivar Grandes Culturas, Pelotas, n.65, p. 06-08, 2004.

BLEICHER, E.; ALMEIDA, T.H.M. Dispersão horizontal do bicudo do algodoeiro (Anthonomus grandis, Boh.) no início do ciclo da cultura. In: CONGRESSO BRASILEIRO DE ENTOMOLOGIA, II Encontro sobre moscas-das-frutas, 12., 1989. Belo Horizonte, MG. Resumos. Belo Horizonte: SEB, 1989. p.396.

BLEICHER, E.; ALMEIDA, T.H.M. Dispersão horizontal do bicudo do algodoeiro (Anthonomus grandis, Boh.). Anais da Sociedade Entomológica do Brasil, Londrina, v.20, n.1, p.76-80, 1991.

BLEICHER, E.; QUINTELA, E.D.; OLIVEIRA, I.S.R.; QUINDERÉ, M.A.W. Efeito do fungo Beauveria Bassiana (Bals.) Vuill. e inseticidas na população do bicudo do algodoeiro, Anthonomus grandis, Boh. Anais da Sociedade Entomológica do Brasil, Londrina, v.23, n.1, p.131-134, 1994.

BRAGA SOBRINHO, R.; LUKEFAHR, M.J. Modificações na armadilha de feromônio "HARDEE" e o aumento na eficiência na captura do bicudo do algodoeiro, Anthonomus grandis BOHEMAN. In: CONGRESSO BRASILEIRO DE ENTOMOLOGIA, 9., 1984a. Londrina, PR. Resumos. Londrina: SEB, 1984b. p.94.

BRAGA SOBRINHO, R.; LUKEFAHR, M.J. Ocorrência de diapausa no bicudo do algodoeiro, Anthonomus grandis BOHEMAN, na região Nordeste do Brasil. In: CONGRESSO BRASILEIRO DE ENTOMOLOGIA, 9., 1984b. Londrina, PR. Resumos. Londrina: SEB, 1984a. p.95.

BRAGA SOBRINHO, R.; SOARES, J.J.; MESQUITA, C.K. DE; ARAÚJO, L.H.A.; ALMEIDA, R.P. DE. Flutuação populacional do bicudo do algodoeiro. In: CONGRESSO BRASILEIRO DE ENTOMOLOGIA, 13; I SIMPÓSIO INTERNACIONAL SOBRE BICUDO DO ALGODOEIRO; II ENCONTRO SOBRE "COCHONILHA" DA PALMA FORRAGEIRA; III ENCONTRO SOBRE MOSCAS-DAS-FRUTAS, 1991. Recife, PE. Resumos. Londrina: SEB, 1991. p.576.

BRAVO, L.K.B.; CHAGAS, G.A.; CLAUDINO, D.; MATA, R.A.; SUJII, E.; FONTES, E.; PAULA, D.P.; PIRES, C.S.S. Avaliação da ocorrência de dormência reprodutiva em populações do bicudo-do-algodoeiro da região do Distrito Federal e entorno. In: CONGRESSO BRASILEIRO DE ENTOMOLOGIA, 23., 2010. Natal, RN. Resumos. Natal: SEB, 2010.

BROGLIO-MICHELETTI, S.M.F. Bioecologia de Anthonomus grandis Boheman, 1943 (Coleoptera: Curculionidae), em laboratório e campo. In: CONGRESSO BRASILEIRO DE ENTOMOLOGIA, 13. E I SIMPÓSIO INTERNACIONAL SOBRE BICUDO DO ALGODOEIRO, II ENCONTRO SOBRE "COCHONILHA" DA PALMA FORRAGEIRA, III ENCONTRO SOBRE MOSCAS-DAS-FRUTAS, 1991. Recife, PE. Resumos. Londrina: SEB, 1991. p.575.

BRUGNERA, P. Bicudo em algodão. Cultivar Grandes Culturas, Pelotas, n.124, p.28-29, 2009.
BRUNETTA, P.S.F.; OLIVEIRA, G.R.; FIGUEIRA, E.L.Z.; RAMOS, H.B.; SILVA, M.C.M.; CAVALCANTI, K.L.; GROSSI DE SÁ, M.F. Prospecção de variantes de toxinas cry com alta especificidade e toxicidade contra o bicudo-do-algodoeiro (Anthonomus grandis) e a lagarta-do-cartucho-do-milho (Spodoptera frugiperda). In: CONGRESSO BRASILEIRO DE ALGODÃO, 8. 2005. Salvador, BA. Resumos. 2005.

BUSOLI, A.C.; MICHELOTTO, M.D. Comportamento do bicudo: fechando o cerco. Cultivar Grandes Culturas, Pelotas, n.72, p. 18-22, 2005.

BUSOLI, A.C.; PAZINI, W.C.; CRISPOLIN, F.A. DIBLLI, W. Aspectos bioecológicos de Anthonomus grandis $\mathrm{BOH}$. (Coleoptera, Curculionidae) aplicados no MIP-Algodoeiro. In: CONGRESSO BRASILEIRO DE ENTOMOLOGIA, 13. E I SIMPÓSIO INTERNACIONAL SOBRE BICUDO DO ALGODOEIRO, ॥ ENCONTRO SOBRE "COCHONILHA" DA PALMA FORRAGEIRA, III ENCONTRO SOBRE MOSCAS-DAS-FRUTAS, 1991. Recife, PE. Resumos. Londrina: SEB, 1991. p.572.

BUSOLI, A.C.; PEREIRA, F.F.; GÓMEZ LOPÉZ, V.A.; SOARES, J.J.; MELO, R.S.; ALMEIDA, C.A. Preferência alimentar do bicudo-doalgodoeiro por frutos de diferentes cultivares e idades. Pesquisa Agropecuária Brasileira, Brasília, v.39, n.2, p.101-104, 2004.

CAMARGO, L.M.P.C.A.; BATISTA FILHO, A.; CRUZ, B.P.B. Ocorrência do fungo Beauveria sp. patogênico ao "bicudo" do algodoeiro (Anthonomus grandis Boheman) na região de Campinas, Estado de S. Paulo. O Biológico, São Paulo, v. 50, p. 65-68, 1984

CAMARGO, L.M.P.C.A.; BATISTA FILHO, A.; CRUZ, B.P.B. Susceptibilidade do "bicudo" do algodoeiro (Anthonomus grandis Boheman) à ação dos fungos Beauveria bassiana (Balsamo) Vuillemin e Metarhizium anisopliae (Metsch.) Sorokin. O Biológico, São Paulo, v.51, n.8, p.205-208, 1985.

CAMPANHOLA, C.; GABRIEL, D.; MARTIN, D.F.; CALCAGNOLO, G. Levantamento deadultos debicudo(Anthonomus grandis)BOHEMAN, 1843 durante a safra 83/84, em alguns municípios do Estado de São Paulo. In: CONGRESSO BRASILEIRO DE ENTOMOLOGIA, 9., 1984. Londrina, PR. Resumos. Londrina: SEB, 1984. p.92.

CAMPANHOLA, C.; MARTIN, D.F.; SCHATTAN, S. Algumas consequências da presença do bicudo-do-algodoeiro na região infestada de Campinas e Sorocaba, Estado de São Paulo, na safra 83/84. Pesquisa Agropecuária Brasileira, v.23, n.8, p.811-823, 1988a.

CAMPANHOLA, C.; GABRIEL, D.; MARTIN, D.F.; CALCAGNOLO, G. Levantamento de adultos de bicudo Anthonomus grandis Boheman, 1843 (Coleoptera, Curculionidae) utilizando armadilhas com feromônio, em alguns municípios do estado de São Paulo. Anais da Sociedade Entomológica do Brasil, v. 17, n.1, p.135-156, 1988b.

CARVALHO, L.H. Destruição de soqueiras. Cultivar Grandes Culturas, Pelotas, n.34, p.06-08, 2001.

CARVALHO L.H; CALCAGNOLO, G.; FUZATTO, M.G.; SILVA, M.N.D.A; CHIAVEGATTO, E.J.; GRID-PAPP, I.L.; CAVALIERI, P.A.; CIA, E. Particularidade na sintomatologia de ataque do bicudo do algodoeiro (Anthonomus grandis Boheman, 1843) em culturas paulistas. IAC: Boletim Científico, 1, Campinas, SP: IAC, 1984, 14p. 
CARVALHO, L.P.; LUKEFHAR, M.J.; FARIAS, F.J.C.; VIEIRA, R.M.; MOREIRA, J.A.N.; COSTA, J.N. Seleção de algodoeiro com resistência ao bicudo. Pesquisa Agropecuária Brasileira, Brasília, v.31, n.3, p.195-199, 1996.

CARVALHO, S.L.; FERNANDES, W.D.; PATEL, P.N.; HABIB, M.E.N. Parasitismo por Bracon vulgaris ASHMEAD (Hymenoptera: Braconidae) em Anthonomus grandis Boheman 1843 (Coleoptera, Curculionidae) em área de algodão sem medidas de controle. In: CONGRESSO BRASILEIRO DE ENTOMOLOGIA, 14., 1993. Piracicaba, SP. Resumos. Piracicaba: SEB, 1993. p.278.

CARVALHO, S.L.; SANTOS, M.G.. Parasitismo em Anthonomus grandis Boheman, 1843 (Coleoptera, Curculionidae) por Bracon vulgaris Ashmed (Hymenoptera, Braconidae) em diferentes níveis das plantas de uma cultura de algodão. In: CONGRESSO BRASILEIRO DE ENTOMOLOGIA, 17., 1998. Rio de Janeiro, RJ. Resumos. Rio de Janeiro: SEB, 1998. p.440.

CARVALHO, S.L.; SANTOS, M.G. Interações entre Bracon vulgaris ASHMED (Hymenoptera: Braconidae) e seu hospedeiro Anthonomus grandis BOHEMAN, 1843 (Coleoptera: Curculionidae) em cultura de algodão sem medidas de controle. In: CONGRESSO BRASILEIRO DE ENTOMOLOGIA, 16., 1997. Salvador, BA. Resumos. Salvador: SEB/Embrapa-CNPMF, 1997. p.222-223.

CASTILHO, R.C.; MIRANDA, J.E.; SILVA, C.A.D. Efeito do tubo mata bicudo na redução populacional do bicudo Anthonomus grandis no período da entressafra. In: CONGRESSO BRASILEIRO DE ENTOMOLOGIA, 20., 2004a. Gramado, RS. Resumos. Gramado: SEB, 2004. p.556.

CASTILHO, R.C.; MIRANDA, J.E; SILVA, C.A.D. Avaliação da eficiência do tubo mata bicudo em pequenas propriedades cotonícolas do agreste do Estado da Paraíba. 2000. In: CONGRESSO BRASILEIRO DE ENTOMOLOGIA, 20., 2004b. Gramado, RS. Resumos. Gramado: SEB, 2004. p.556.

CASTRO, D.F.; RAMIRO, Z.A.; CORREIA. M.F.M. Distribuição dos danos ocasionados pelo "bicudo" do algodoeiro, Anthonomus grandis BOHEMAN, 1843 (Coleoptera, Curculionidae) na planta. In: CONGRESSO BRASILEIRO DE ENTOMOLOGIA, 13. E I SIMPÓSIO INTERNACIONAL SOBRE BICUDO DO ALGODOEIRO, II ENCONTRO SOBRE "COCHONILHA” DA PALMA FORRAGEIRA, III ENCONTRO SOBRE MOSCAS-DAS-FRUTAS, 1991. Recife, PE. Resumos. Londrina: SEB, 1991. p.579.

CASSETARI NETO, D.; MACHADO, A.Q.; ANDRADE JUNIOR, E.R. de. Implantação do vazio sanitário em algodão. Cultivar Grandes Culturas, Pelotas, n. 113, p. 36-38, 2008.

CHAGAS, G.A; BRAVO, L.K.B.; SOUSA, A.A.T.C.; MATA, R.A.; PAULA, D.P.; FONTES, E.; TOREZANI, K.R.S.; PIRES, C.S.S. Flutuação populacional do bicudo do algodoeiro na região de Cristalina-GO. In: CONGRESSO BRASILEIRO DE ENTOMOLOGIA, 23., 2010. Natal, RN. Resumos. Natal: SEB, 2010.

CHAIB, S.L.; LUPORINI, M.P.M. Observações sobre Anthonomus grandis, Boheman 1843 (Coleoptera: Curculionidae), em propriedades rurais na região de Campinas, SP, ano II e III. In: CONGRESSO BRASILEIRO DE ENTOMOLOGIA, VII Encontro de Mimercologistas, I Encontro sobre moscas-das-frutas, 11., 1987. Campinas, SP. Resumos. Campinas: SEB, 1987. p. 100.
CHITARRA, L.G. Qualidade de sementes de algodão. Cultivar Grandes Culturas, Pelotas, n. 100, p.14-16, 2007.

CLAUDINO, D.; TIMBÓ, R.V.; SCHMIDT, F.; SUJII, E.R.; FONTES, E.M.G.; PIRES, C.S.S.; PAULA, D.P. Estudo morfofisiológico da dormência reprodutiva em bicudo-do-algodoeiro Anthonomus grandis (Coleoptera: Curculionidae) de população tropical. In: CONGRESSO BRASILEIRO DE ENTOMOLOGIA, 23., $2010 \mathrm{c}$. Natal, RN. Resumos. Natal: SEB, 2010 .

CLAUDINO, D.; TIMBÓ, R.V.; SCHMIDT, F.; SUJII, E.R.; FONTES, E.M.G.; PIRES, C.S.S.; PAULA, D.P. Influência da alimentação na dormência reprodutiva do bicudo-do-algodoeiro. In: CONGRESSO BRASILEIRO DE ENTOMOLOGIA, 23., $2010 \mathrm{~b}$. Natal, RN. Resumos. Natal: SEB, $2010 b$.

CLAUDINO, D.; TIMBÓ, R.V.; SCHMIDT, F.; SUJII, E.R.; FONTES, E.M.G.; PIRES, C.S.S.; PAULA, D.P. Padrão de emergência do bicudo-do-algodoeiro Anthonomus grandis (Coleoptera: Curculionidae) de estruturas reprodutivas do algodão. In: CONGRESSO BRASILEIRO DE ENTOMOLOGIA, 23., 2010a. Natal, RN. Resumos. Natal: SEB, $2010 \mathrm{c}$.

CONFALONIERI, V.A.; SCATAGLINI, M.A.; LANTERI, A. Origin and dispersal of the cotton boll weevil (Coleoptera: Curculionidae) in South America: a mtDNA Phylogeographic study. In: CONGRESSO BRASILEIRO DE ENTOMOLOGIA/CONGRESSO INTERNACIONAL DE ENTOMOLOGIA, 18., 2000. Foz do Iguaçu, PR. Resumos. Foz do Iguaçu: SEB, 2000. p.567.

COUTINHO, J. L. B.; CAVALCANTI, V. A. L. B. Utilização do fungo Beauveria bassiana no controle biológico do bicudo do algodoeiro em Pernambuco. Revista Agropecuária Brasileira, Brasília, v.23, n.5, p.455-461, 1988.

COUTINHO, J.L.B.; OLIVEIRA, J.V. Patogenicidade do isolado I-149Bb de Beauveria bassiana (Bals.) Vuill., em relação a adultos de Anthonomus grandis Boheman, 1843 (Col.: Curculionidae). In: CONGRESSO BRASILEIRO DE ENTOMOLOGIA, II Encontro sobre moscas-das-frutas, 12., 1989. Belo Horizonte, MG. Resumos. Belo Horizonte: SEB, 1989. p.219.

COUTINHO, J.L.B.; OLIVEIRA, J.V. Patogenicidade do isolado I-149Bb de Beauveria bassiana (Bals.) Vuil. a adultos de Anthonomus grandis (Coleoptera: Curculionidae). Anais da Sociedade Entomológica do Brasil, Londrina, v.20, n. 1, p.199-207, 1991.

COELHO, R.R.; SOUZA JR., J.D.; MACÊDO, L.L.P., M.F.G. Expressão de dsRNA de fragmentos dos genes de vitelogenina e de receptor de ecdisona de Anthonomus grandis (Coleoptera: Curculionidae) em Escherichia coli. In: CONGRESSO BRASILEIRO DE ENTOMOLOGIA, 23., 2010. Natal, RN. Resumos. Natal: SEB, 2010.

CUNHA, D.N.; VENZON, M.; CRUZ, F.A.R.; MATA, R.A. ; FONTES, E.M.G. Longevidade do bicudo-do-algodoeiro Anthonomus grandis Boheman alimentado com pólen de crotalária. In: CONGRESSO BRASILEIRO DE ENTOMOLOGIA, 23., 2010. Natal, RN. Resumos. Natal: SEB, 2010.

DEGRANDE, P.E. Validação do manejo integrado de pragas aplicado ao algodoeiro o Mato Grosso do Sul através de campos demonstrativos. In: CONGRESSO BRASILEIRO DE ENTOMOLOGIA, 14., 1993, Piracicaba, SP. Resumos. Piracicaba: SEB, 1993. p. 574. 
DEGRANDE, P.E. Táticas de controle do bicudo do algodoeiro. Correio Agrícola, n.2, p.19-23, 1994.

DEGRANDE, P.E. Pragas em algodão. Cultivar Grandes Culturas, Pelotas, n.10, p.14-16, 1999.

DEGRANDE, P.E. Manejo para a próxima safra. Cultivar Grandes Culturas, Pelotas, n.20, p.16-20, 2000.

DEGRANDE, P.E. Manejo de praga em algodão. Cultivar Grandes Culturas, Pelotas, n.42, p.14-16, 2002.

DEGRANDE, P.E. Estratégias de controle do bicudo. Cultivar Grandes Culturas, Pelotas, n.62, p.19-20, 2004a.

DEGRANDE, P.E. Níveis de controle das pragas do algodoeiro. Atualidades Agrícolas, p.22-23, 2004b.

DEGRANDE, P.E. Ameaça do bicudo exige organização e empenho de todos. Visão Agrícola, n.6, p.55-58, 2006.

DEGRANDE, P.E.; CARVALHO, E.; BREDA, C.E. Oeste baiano contra o bicudo. Cultivar Grandes Culturas, Pelotas, n.30, p.0812, 2001.

DEGRANDE, P.E.; FERNANDES, M.G. O Brasil com Bt. Cultivar Grandes Culturas, Pelotas, n.67, p. 16-21, 2006.

DEGRANDE, P.E. ; IDE, M.A.; NAKANO, O.; PARRA, J.R.P. Efeito de diversas temperaturas sobre a emergência do bicudo do algodoeiro (Anthonomus grandis Boheman, 1843) (Coleoptera-Curculionidae). In: CONGRESSO BRASILEIRO DE INICIAÇÃO CIENTÍFICA EM CIÊNCIAS AGRÁRIAS, 3., 1983, Florianópolis, SC. Resumos. Florianópolis, p.33, 1983.

DEGRANDE, P.E.; JORGE, W.; SCHAFER, S. Goiás contra o bicudo - Fase II. Cultivar Grandes Culturas, Pelotas, n.55, p.0609, 2003.

DEGRANDE, P.E.; SANTOS, W.J.; SILVA, A.F.C.P. Programa nacional contra o bicudo. Cultivar Grandes Culturas, Pelotas, n.68, p.08-10, 2004.

DEGRANDE, P.D.; SILVA, M.A.O.E.; MIRANDA, J.E.; SILVA, M.S.; SANTOS, W.J. Áreas piloto de supressão do bicudo do algodoeiro (Anthonomus grandis) no estado de Goiás. In: CONGRESSO BRASILEIRO DE ALGODÃO, 7.; 2009, Foz do Iguaçu, PR. Sustentabilidade da Cotonicultura Brasileira e Expansão dos Mercados: Anais... Campina Grande: Embrapa Algodão, 2009. p.305-312.

DEGRANDE, P.E.; SOUZA; L.C.F.; OLIVEIRA, M.A.; BARROS, R.; FERNANDES, M.G. Suscetibilidade de genótipos de algodoeiro ao bicudo. Arquivos do Instituto Biológico, São Paulo, v.69, n.4, p.83-86, 2002.

DEL SARTO, R.P.; SILVA, M.C.M.; CRUZ, C.C.M.; FIGUEIRA, E.L.Z.; TEIXEIRA, F.R.; MARANHÃO, A.Q.; BRÍGIDO, M.M.; COSTA, M.F.; COUTINHO, M.V.; BEZERRA, I.C.; DE SÁ ,M.F.G. Seleção de inibidores de $\alpha$-amilases específicos para Anthonomus grandis. In: CONGRESSO BRASILEIRO DE ALGODÃO. 5., 2005, Salvador, BA. Resumos. Salvador: 2005.
DIAS, J.M.; LEMOS, W.P.; MEDEIROS, R,S.; WANDERLEY, P.A.; RAMALHO, C.I.; RAMALHO, F.S. Reprodução de Catolaccus grandis (Burks) (Hymenoptera, Pteromalidae), parasitoide do bicudo-do-algodoeiro tendo como hospedeiro larvas de Euscepes postfasciatus (Fairmaire) (Coleoptera, Curculionidae). In: CONGRESSO BRASILEIRO DE ENTOMOLOGIA, 17., 1998a, Rio de Janeiro, RJ. Resumos. Rio de Janeiro: SEB, 1998. p.552.

DIAS, J.M.; MEDEIROS, R.S.; LEMOS, W.P.; WANDERLEY, P.A.; RAMALHO, C.I.; RAMALHO, F.S. Metodologia de criação de Euscepes postfasciatus (Fairmaire) (Coleoptera, Curculionidae) hospedeiro alternativo de Catolaccus grandis (Burks) parasitoide do bicudo-do-algodoeiro. In: CONGRESSO BRASILEIRO DE ENTOMOLOGIA, 17., 1998b. Rio de Janeiro, RJ. Resumos. Rio de Janeiro: SEB, 1998. p.553.

DIAS, J.M.; RAMALHO, F.S. Efeitos de hospedeiros alternativos na biologia de Catolaccus grandis (Burks) (Hymenoptera: Pteromalidae), parasitoide de Anthonomus grandis Boheman (Coleoptera: Curculionidae). Neotropical Entomology, v.32, n.2, p.305-310, 2003.

DIAS, S.C.; SILVA, M.C.M.; OLIVEIRA NETO, O.B.; MAGALHÃES, C.P.; TEIXEIRA, F.R.; FRANCO, O.L.; FILGUEIRA, E.L.Z.; LAUMANN, R.A.; MELLO, F.; SÁ, M.F.G. Functional expression of A a-amylase/trypsin inhibitor domain from rye and its potential use in the control of cotton boll weevil (Anthonomus grandis). In: CONGRESSO BRASILEIRO DE ENTOMOLOGIA, 20., 2004, Gramado, RS. Resumos. Gramado: SEB, 2004. p.261.

DUMAS, V.F.; MARTINS, E.S.; RAMOS, F.R.; PRAÇA, L.B.; MONNERAT, R.G. Caracterização molecular de estirpes de Bacillus thuringiensis tóxicas ao bicudo do algodoeiro (Anthonomus grandis Boheman, 1843). In: CONGRESSO BRASILEIRO DE ENTOMOLOGIA, 21., 2006, Recife, PE. Resumos. Recife: SEB, 2006.

FARIAS, F.J.C.; LUKEFAHR, M.J.; ALMEIDA, R.P. Teste de resistência ao bicudo (Anthonomus grandis Boheman) em progênies oriundas de raças primitivas de algodão herbáceo. In: CONGRESSO BRASILEIRO DE ENTOMOLOGIA, 14., 1993,. Piracicaba, SP. Resumos. Piracicaba: SEB, 1993. p.384.

FARIAS, F.J.C.; LUKEFAHR, M.J.; COSTA, J.N.; FREIRE, E.C. Comportamento de progênies oriundas de raças primitivas de algodão herbáceo frente ao ataque do bicudo. Pesquisa Agropecuária Brasileira, v.34, n.12, p. 2235-2240, 1999.

FERNANDES, L.M.; BADJI, C.A.; MICHELIN, L.H.; FRAGOSO, D.B. Monitoramento populacional do bicudo do algodoeiro, Anthonomus grandis, com armadilha de feromônio, em Palmas - TO. In: CONGRESSO BRASILEIRO DE ENTOMOLOGIA, 21., 2006, Recife, PE. Resumos. Recife: SEB, 2006.

FERNANDES, W.D.; CARVALHO, S.L.; HABIB, M.E.N. Avaliação da preferência alimentar e de oviposição de Anthonomus grandis em áreas algodoeiras sem controle químico. In: CONGRESSO BRASILEIRO DE ENTOMOLOGIA, 13.; I SIMPÓSIO INTERNACIONAL SOBRE BICUDO DO ALGODOEIRO; II ENCONTRO SOBRE "COCHONILHA" DA PALMA FORRAGEIRA; III ENCONTRO SOBRE MOSCAS-DAS-FRUTAS, 1991, Recife, PE. Resumos. Londrina: SEB, 1991. p.578. 
FERNANDES, W.D.; CARVALHO, S.L.; HABIB, M. Between-Season attraction of Cotton boll beevil, Anthonomus Grandis Boh. (Coleoptera: Curculionidae) adults by its aggregation pheromone. Scientia Agricola, v.58, n.2, p.229-234, 2001.

FERNANDES, W.D.; FERRAZ, J.M.G.; FERRACINI, V.L.; SANTOS, A.B. Avaliação do efeito deterrente de alguns extratos vegetais sobre Anthonomus grandis Boheman, 1843 (Coleoptera: Curculionidae) em condições de laboratório. In: CONGRESSO BRASILEIRO DE ENTOMOLOGIA, 14., 1993, Piracicaba, SP. Resumos. Piracicaba: SEB, 1993. p.573.

FERNANDES, W.D.; FERRAZ, J.M.G.; FERRACINI, V.L.; HABIB, M.E.M. Deterrência alimentar e toxidez de extratos vegetais em adultos de Anthonomus grandis Boheman, 1843 (Coleoptera: Curculionidae). Anais da Sociedade Entomológica do Brasil, Londrina, v.25, n.3, p.553-555, 1996.

FERREIRA FILHO, J.B.S.; GAMEIRO, A.H. Avaliação econômica do algodão Bolgard ${ }^{\circledR}$ no Brasil. In: CONGRESSO BRASILEIRO DE ENTOMOLOGIA, 19., 2002, Manaus, AM. Resumos. Manaus: INPA/SEB, 2002. p.312-313.

FRANCO, O.L.; DIAS, S.C.; MELO, F.R.; OLIVEIRA-NETO, O.B.; BLOCH JR., C.; MONNERAT, R.G.; SÁ, M.F.G. Effects in vitro and in vivo of soybean kunitz trypsin inhibitors against the boll weevil Anthonomus grandis. In: CONGRESSO BRASILEIRO DE ENTOMOLOGIA/ CONGRESSO INTERNACIONAL DE ENTOMOLOGIA, 18., 2000, FOZ do Iguaçu, PR. Resumos. Foz do Iguaçu: SEB, 2000. p.521.

GABRIEL, D. Aumento na densidade de botões florais do algodoeiro após oviposição pelo bicudo. Arquivos do Instituto Biológico, São Paulo, v.63, n.2, p.69-71, 1996.

GABRIEL, D. Boll weevil: Biology in alternate host by artificial oviposition. In: CONGRESSO BRASILEIRO DE ENTOMOLOGIA/ CONGRESSO INTERNACIONAL DE ENTOMOLOGIA, 18., 2000, Foz do Iguaçu, PR. Resumos. Foz do Iguaçu: SEB, 2000. p.444.

GABRIEL, D. Levantamento da população do bicudo do algodoeiro Anthonomus grandis BOHEMAN, 1843 (Coleoptera, Curculionidae) na entressafra utilizando-se armadilhas com feromônio. Biológico, São Paulo, v.50, n.1 1, p. 247-261, 1984 b.

GABRIEL, D. Levantamento da população do bicudo do algodoeiro Anthonomus grandis BOHEMAN, 1843 (Coleoptera, Curculionidae) no período de entressafra, utilizando armadilhas com feromônio. In: CONGRESSO BRASILEIRO DEENTOMOLOGIA, 9., 1984. Londrina, PR. Resumos. Londrina: SEB, 1984a. p. 93.

GABRIEL, D. Longevidade do bicudo do algodoeiro Anthonomus grandis Boh., criado em hospedeiras alternativas no laboratório. Arquivos do Instituto Biológico, São Paulo, v.69, n.3, p.123126, 2002a.

GABRIEL, D. Ocorrência de himenópteros parasitoides do bicudo do algodoeiro Anthonomus grandis Boheman, 1843 (Coleoptera: Curculionidae). In: REUNIÃO ANUALDO INSTITUTO BIOLÓGICO, 5. Resumos. p. 17. (Resumo no 033), 1992.

GABRIEL, D. Relação entre temperatura da superfície do solo e emergência do bicudo do algodoeiro Anthonomus grandis Boh. (Coleoptera, Curculionidae). Anais da Sociedade Entomológica do Brasil, v.24, n.3, p. 543-550, 1995.
GABRIEL, D. Uso do inseticida propoxur em armadilhas com feromônio utilizadas na captura do bicudo do algodoeiro Anthonomus grandis Boheman, 1843. (Coleoptera; Curculionidae). Biológico, São Paulo, v.52, n.4-6, p.49-51, 1986.

GABRIEL, D. Avaliação de malváceas cultivadas como hospedeiras reprodutivas de Anthonomus grandis Boh., 1843, no laboratório. In: CONGRESSO BRASILEIRO DE ENTOMOLOGIA, 19., 2002a, Manaus, AM. Resumos. Manaus: INPA/SEB, 2002b. p.20.

GABRIEL, D. Avaliação de malváceas cultivadas como hospedeiras alternativas para a reprodução do bicudo do algodoeiro Anthonomus grandis Boh. 1843, no laboratório. Arquivos do Instituto Biológico, São Paulo, v.69, n.3, p.69-76, 2002c.

GABRIEL, D.; BELTRAMELLI, F.M. Avaliação da propriedade antialimentar do nim Azadirachta indica A. JUSS., para o bicudo do algodoeiro em condições de laboratório. In: CONGRESSO BRASILEIRO DE ALGODÃO. 5., 2005, Salvador, BA. Resumos. 2005.

GABRIEL, D.; BLANCO, F.M.G.; ROBERG, G.M.B.R. Suscetibilidade de genótipos de algodoeiro ao ataque do bicudo Anthonomus grandis Boh., 1843, em condições de campo. In: CONGRESSO BRASILEIRO DE ALGODÃO. 5., 2005, Salvador, BA. Resumos. 2005.

GABRIEL, D.; BLANCO, F.M.G. Efeito de linhagens com características morfológicas mutantes sobre o bicudo e a produção do algodoeiro. Arquivos do Instituto Biológico, São Paulo, v.76, n.2, p.211-215, 2009.

GABRIEL, D.; BLANCO, F.M.C; MATIOLI, A.L. Avaliação de cultivares transgênicas de algodoeiro quanto aos danos e a reprodução de Anthonomus grandis Boh., 1843 (Coleoptera; Curculionidae). In: CONGRESSO BRASILEIRO DE ALGODÃO, 7., 2009, Foz do Iguaçu, PR. Sustentabilidade da Cotonicultura Brasileira e Expansão dos Mercados: Anais... Campina grande: Embrapa Algodão, 2009. p.462-468.

GABRIEL, D.; CALCAGNOLO, G.; TANCINI, R.S.; DIAS NETTO, N. Estudos de biologia do Anthonomus grandis BOHEMAN, 1843 (Coleoptera, Curculionidae), em condições de laboratório. $O$ Biológico, São Paulo, v.50, n.10, p.83-89, 1986.

GABRIEL, D.; DIAS NETO, N. Observações sobre o comportamento de Anthonomus grandis Boheman, 1843 (Coleoptera: Curculionidae) em condições de campo. In: CONGRESSO BRASILEIRO DE ENTOMOLOGIA, II Encontro sobre moscas-das-frutas, 12., 1989, Belo Horizonte, MG. Resumos. Belo Horizonte: SEB, 1989. p.38.

GABRIEL, D.; DIAS NETO, N.; NOVO, J.P.S. Observações sobre o comportamento de Anthonomus grandis BOHEMAN, 1843 (Coleoptera, Curculionidae) em condições de campo. Safras 1988/89 e 1989/90. In: CONGRESSO BRASILEIRO DE ENTOMOLOGIA, 13., e I SIMPÓSIO INTERNACIONAL SOBRE BICUDO DO ALGODOEIRO, II ENCONTRO SOBRE "COCHONILHA" DA PALMA FORRAGEIRA, III ENCONTRO SOBRE MOSCAS-DAS-FRUTAS, 1991, Recife, PE. Resumos. Londrina: SEB, 1991 b. p.577. 
GABRIEL, D.; DIAS NETO, N.; NOVO, J.P.S. Estudos sobre o comportamento do bicudo do algodoeiro Anthonomus grandis BOHEMAN, 1843 (Coleoptera, Curculionidae) em condições de campo. Anais da Sociedade Entomológica do Brasil, v.21, n.1, p.41-57, 1992.

GABRIEL, D.; MATIOLI, A.L.; BLANCO, F.M.G. Avaliação de danos por Anthonomus grandis Boh., 1843 (Coleoptera: Curculionidae) em sistemas de cultivo adensado e convencional e sua relação com a produção do algodoeiro. In: CONGRESSO BRASILEIRO DE ALGODÃO. 8., 201 1, São Paulo, SP. Resumos. 201 1. p.88.

GABRIEL, D.; MUNIZ, J.P. Efeito da temperatura do solo na mortalidade dos imaturos do bicudo do algodoeiro Anthonomus grandis BOHEMAN, 1843 (Coleoptera, Curculionidae). In: CONGRESSO BRASILEIRO DE ENTOMOLOGIA, 14., 1993, Piracicaba, SP. Resumos. Piracicaba: SEB, 1993. p.37.

GABRIEL, D.; SCARPELLINI, J.R.; BOLONHESI, D. Influência da época de plantio na produtividade do algodoeiro, em áreas infestadas pelo bicudo Anthonomus grandis BOHEMAN, 1843. In: CONGRESSO BRASILEIRO DE ENTOMOLOGIA, 16., 1997, Salvador, BA. Resumos. Salvador: SEB/Embrapa-CNPMF, 1997. p.284.

GABRIEL, D.; TANCINI, R.S. Estudos de biologia do Anthonomus grandis BOHEMAN, 1843 (Coleoptera, Curculionidae), no laboratório. In: CONGRESSO BRASILEIRO DE ENTOMOLOGIA, 10., 1986, Rio de Janeiro, RJ. Resumos. Londrina: SEB, 1986. p.97.

GABRIEL, D.; TANCINI, R.S. Levantamentos de Anthonomus grandis BOHEMAN, 1843 (Coleoptera, Curculionidae) em hibernação utilizando-se amostragem de cobertura de solo. In: CONGRESSO BRASILEIRO DE ENTOMOLOGIA, II Encontro sobre moscas-das-frutas, 12., 1989, Belo Horizonte, MG. Resumos. Belo Horizonte: SEB, 1989. p. 109.

GABRIEL, D.; TANCINI, R.S.; LUPORINI, M.P.M.; FERREIRA, A.F.; COELHO, V.A. Levantamentos de Anthonomus grandis BOHEMAN, 1843 (Coleoptera, Curculionidae), utilizando-se amostragem de cobertura do solo, para estudos de hibernação. Anais da Sociedade Entomológica do Brasil, Londrina, v.20, n. 1 , p.89-98, 1991a.

GABRIEL D.; TEÓFILO, T.S.; BLANCO, F.M.G.; FRANCO, D.A.S Avaliação de genótipos de algodoeiro quanto à infestação pelo bicudo Anthonomus grandis Boh., 1843, em condições de campo. In: CONGRESSO BRASILEIRO DE ENTOMOLOGIA, 21. 2006, Recife, PE. Resumos. Recife: SEB, 2006.

GARCIA, D.L.E.; DEGRANDE, P.E.; MIRANDA, J.E.; LIMBERTE, R. Importância da adoção e execução do plano de controle do bicudo do algodoeiro (Anthonomus grandis). In: CONGRESSO BRASILEIRO DE ALGODÃO, 7.; 2009, Foz do Iguaçu, PR. Sustentabilidade da Cotonicultura Brasileira e Expansão dos Mercados: Anais... Campina Grande: Embrapa Algodão, 2009. p.313-318.

GIELFI, F.S.; BUSOLI, A.C. Perdas em algodão em caroço atribuídas ao bicudo do algodoeiro, Anthonomus grandis Boheman, 1843 (Coleoptera: Curculionidae) na CV. IAC-20. In: CONGRESSO BRASILEIRO DE ENTOMOLOGIA, 17., 1998a, Rio de Janeiro, RJ. Resumos. Rio de Janeiro: SEB, 1998a. p. 138.
GIELFI, F.S.; BUSOLI, A.C. Níveis de danos de Anthonomus grandis Boheman, 1843 (Coleoptera: Curculionidae) e produtividade do algodão (Gossypium hirsutum L.) CV. IAC20. In: CONGRESSO BRASILEIRO DE ENTOMOLOGIA, 17., 1998b, Rio de Janeiro, RJ. Resumos. Rio de Janeiro: SEB, 1998 b. p.139.

GIELFI, F.S.; BUSOLI, A.C. Damage levels and evaluation of cotton yield losses caused by Anthonomus grandis (Coleoptera: Curculionidae). In: CONGRESSO BRASILEIRO DE ENTOMOLOGIA/CONGRESSO INTERNACIONAL DE ENTOMOLOGIA, 18., 2000, Foz do Iguaçu, PR. Resumos. Foz do Iguaçu: SEB, 2000. p.62.

GIOMETTI, F.H.C.; WENZEL, I.M.I.; ALMEIDA, J.E.M.; ALMEIDA, A.M.B. Patogenicidade de diferentes isolados de Beauveria bassiana para o controle de Anthonomus grandis (Coleoptera: Curculionidae). In: CONGRESSO BRASILEIRO DE ENTOMOLOGIA, 21., 2006, Recife, PE. Resumos. Recife: SEB, 2006.

GIOMETTI, F.H.C.; WENZEL, I.M.I.; ALMEIDA, J.E.M.; LEITE, L.G.; ZAPPELINI, L.O. Seleção de isolados de Beauveria bassiana para o controle de adultos do bicudo-do-algodoeiro Anthonomus grandis (Coleoptera: Curculionidae). Arquivos do Instituto Biológico, São Paulo, v.77, n.1, p.167-169, 2010.

GONÇALVES, N.P.; RODRIGUES, F.; SÁ, T.R.N.; FARIA, M.A.V.R. Avaliação de cepas entomopatogênicas de Beauveria bassiana (Bals.) no controle biológico do bicudo do algodoeiro (Anthonomus grandis, Bohemam). In: CONGRESSO BRASILEIRO DE ALGODÃO. 5., 2005, Salvador, BA. Resumos. 2005

GRAVENA, S. Quem é esse tal de bicudo. Cultivar Grandes Culturas, Pelotas, n.25, p.42-44, 2001.

GRIGOLLI, J.F.J.; SOUZA L.A.; FRAGA, D.F.; FUNICHELLO, M.; RIBEIRO, A.A.; BUSOLI, A.C. Comportamento de alimentação e oviposição do bicudo do algodoeiro Anthonomus grandis Boh. nas cultivares DeltaOpal e NuOpal (Bollgard I ${ }^{\circledR}$ ). In: CONGRESSO BRASILEIRO DE ALGODÃO. 8., 2011 , São Paulo, SP. Resumos. 2011. p.107.

GUTIERREZ, G.S. Bioecologia de Anthonomus grandis Boheman. 1843. 107 p. (Col.: Curculionidae) e seu controle com Beauveria bassiana (Bals.) Vuill. Tese Doutorado - Escola Superior de Agricultura Luiz de Queiroz. Piracicaba, 1986.

HABIB, M.E.M.; FERNADES, W.D. Anthonomus grandis Boheman (Curculionidae) já está na lavoura algodoeira do Brasil. Revista de Agricultura, Piracicaba, v.58, n.1-2, p.74, 1983.

HABIB, M.E.M.; FERNANDES, W.D.; FÁVARO, J.R.A.; ANDRADE, C.F.S. Eficiência do feromônio de agregação e inseticidas químicos no combate ao bicudo, Anthonomus grandis Boheman. Revista de Agricultura, Piracicaba, v.59, p.239-251, 1984a.

HABIB, M.E.M; PIEROZZI JR.,I.; Flutuação populacional de Anthonomus grandis Boh. (Coleoptera, Curculionidae), em algodoais da região de Campinas, SP. In: CONGRESSO BRASILEIRO DE ENTOMOLOGIA, 10., 1986, Rio de Janeiro, RJ. Resumos. Londrina: SEB, 1986. p.386. 
HABIB, M.E.M; PIEROZZI, JR. I.; ANDRADE, C.F.S. Estudos preliminares de manejo integrado de pragas de algodão em regiões de ocorrência do "bicudo", Anthonomus grandis BOHEMAN, 1843. In: CONGRESSO BRASILEIRO DE ENTOMOLOGIA, 9., 1984b, Londrina, PR. Resumos. Londrina: SEB, 1984. p.297.

IONEDA, T.; TAKEMATSU, A.P.; OLIVATI, J.; BELORTE, L.C.C. Estudo sobre densidade populacional de Pectinophora gossypiella (Saunders) lagarta rosada e de Anthonomus grandis Boheman, o bicudo, com feromônios sexuais. In: CONGRESSO BRASILEIRO DE ENTOMOLOGIA, VII Encontro de Mimercologistas, I Encontro sobre moscas-das-frutas, 11, 1987, Campinas, SP. Resumos. Campinas: SEB, 1987. p.280.

JARAMILLO, C.B.J.; ALVES, S.B. Patogenicidade do Metarhizium anisopliae (Metsch.) Sorok., isolado SPL-255 ao bicudo do algodoeiro Anthonomus grandis Boheman. In: CONGRESSO BRASILEIRO DE ENTOMOLOGIA, 10., 1986, Rio de Janeiro, RJ. Resumos. Londrina: SEB, 1986. p.199.

KLESENER, D.F.; BORGES, R.; GARCIA, G.V.; AZEVEDO, P.A.Z.; BARBOSA, L.V.; GONÇALVES, M.W. Avaliação da eficiência e durabilidade do atrativo Iscalure BW/60 para monitoramento do bicudo do algodoeiro Anthonomus grandis (Boheman) (Coleoptera: Curculionidae) na cultura do algodão. In: CONGRESSO BRASILEIRO DE ENTOMOLOGIA, 23., 2010, Natal, RN. Resumos. Natal: SEB, 2010.

KUBO, R.K.; CAMARGO, L.M.P.C.A.; CRUZ, B.P.B. Subsídios para o manejo do bicudo Anthonomus grandis Boheman e flutuação populacional de algumas pragas e seus inimigos naturais em cultura de algodoeiro comercial. In: CONGRESSO BRASILEIRO DE ENTOMOLOGIA, VII Encontro de Mimercologistas, I Encontro sobre moscas-das-frutas, 11., 1987, Campinas, SP. Resumos. Campinas: SEB, 1987. p.282.

LAMAS, F.M. Destruição de soqueiras no algodão. Cultivar Grandes Culturas, Pelotas, n.88, p.10-13, 2007.

LARA, F.M.; SOARES, J.J.; BARBOSA, J.C. Não-preferência para alimentação e oviposição de Anthonomus grandis Boheman, 1843 (Coleoptera: Curculionidae) em genótipos de algodoeiro. In: CONGRESSO BRASILEIRO DE ENTOMOLOGIA, 14., 1993, Piracicaba, SP. Resumos. Piracicaba: SEB, 1993. p.385.

LEMOS, W.P.; MEDEIROS, R.S.; RAMALHO, F.S. Impacto da temperatura nas variáveis reprodutivas de Euborellia annulipes (Lucas) (Dermaptera: Anisolabididae), predador do bicudo-doalgodoeiro. In: CONGRESSO BRASILEIRO DE ENTOMOLOGIA, 17., 1998, Rio de Janeiro, RJ. Resumos. Rio de Janeiro: SEB, 1998a. p.650.

LEMOS, W.P.; MEDEIROS, R.S.; RAMALHO, F.S. Influência da temperatura no desenvolvimento de Euborellia annulipes (Lucas) (Dermaptera: Anisolabididae), predador do bicudodo-algodoeiro. Anais da Sociedade Entomológica do Brasil, Londrina, v.27, n.1, p.67-76, 1998b.

LEMOS, W.P.; MEDEIROS, R.S.; RAMALHO, F.S. Exigência térmicas de Euborellia annulipes (Lucas) (Dermaptera: Anisolabididae) e sua relação com a presa: bicudo-doalgodoeiro. Revista Brasileira de Entomologia, São Paulo, v.43, n. 1/2, p.61-68, 1999.
LIMA JR., I.S.; DEGRANDE, P.E.; MIRANDA, J.E.; SANTOS, W.J. Evaluation of the boll weevil Anthonomus grandis Boheman (Coleoptera: Curculionidae) Suppression Program in the State of Goiás, Brazil. Neotropical Entomology, Londrina, v.42, p.8288,2013

LOPES, M.T.R.; LARA, F.M. Técnica para avaliação da preferência para alimentação de Anthonomus grandis Boh. (Coleoptera: Curculionidae) por genótipos de algodoeiro. Anais da Sociedade Entomológica do Brasil, Londrina, v.25 n.3, p.483-487, 1996.

LUKEFAHR, M.J.; FARIAS, F.J.C.; JONES, J.E.; McCARTY, J.E.; ALMEIDA, R.P. de. Níveis de resistência ao bicudo (Anthonomus grandis Boheman) em linhagens de algodão herbáceo. In: CONGRESSO BRASILEIRO DE ENTOMOLOGIA, 14., 1993, Piracicaba, SP. Resumos. Piracicaba: SEB, 1993a. p.382.

LUKEFAHR, M.J.; FARIAS, F.J.C.; MCCARTY, J.E.; ALMEIDA, R.P. Plant resistence to the boll weevil (Anthonomus grandis Boheman): new sources and recovery of resistence in BC1F5 generation. In: CONGRESSO BRASILEIRO DE ENTOMOLOGIA, 14., 1993, Piracicaba, SP. Resumos. Piracicaba: SEB, 1993b. p.383.

MAGALHÃES, D.M.; BORGES, M.; LAUMANN, R.A.; PADILHA, J.S.; SUJII, E.R.; PIRES, C.S.S.; MORAES, M.C. Defesa induzida de plantas de algodão danificadas pelos insetos Anthonomus grandis, Euschistus heros e Spodoptera frugiperda. In: CONGRESSO BRASILEIRO DE ENTOMOLOGIA, 23., 2010, Natal, RN. Resumos. Natal: SEB, 2010.

MANESSI, O.G. Results from 3 years of bwact use in the national boll weevil suppression program of Paraguay. In: CONGRESSO BRASILEIRO DE ENTOMOLOGIA; CONGRESSO INTERNACIONAL DE ENTOMOLOGIA, 18., 2000, Foz do Iguaçu, PR. Resumos. Foz do Iguaçu: SEB, 2000. p.70.

MARTINS, E.S.; RIBEIRO, B.M.; QUEIROZ, P.R.M.; DUMAS, V.F.; BRAZ, S.V.B.; AGUIAR, R.W.S.; BRAVO, A.; MONNERAT, R.G. Primeiro relato de identificação de receptor para toxinas de Bacillus thuringiensis em Anthonomus grandis. In: CONGRESSO BRASILEIRO DE ENTOMOLOGIA, 23., 2010, Natal, RN. Resumos. Natal: SEB, 2010.

MEDEIROS, R.S.; LEMOS, W.P.; RAMALHO, F.S. Tabelas de vida e de fertilidade de Euborellia annulipes (Lucas) (Dermaptera: Anisolabididae), predador do bicudo-do-algodoeiro. In: CONGRESSO BRASILEIRO DE ENTOMOLOGIA, 17., 1998, Rio de Janeiro, RJ. Resumos. Rio de Janeiro: SEB, 1998. p.648.

MELO, A.B.P; SILVEIRA NETO, S.; CARVALHO, R.P.L. Comparação de armadilhas e formulações de grandlure para coleta do bicudo do algodoeiro (Anthonomus grandis BOHEMAN, 1843). In: CONGRESSO BRASILEIRO DE ENTOMOLOGIA, 10., 1986, Rio de Janeiro, RJ. Resumos. Londrina: SEB, 1986. p.77.

MELO, A.B.P.; SILVEIRA NETO, S.; CARVALHO, R.P.L. Comparação de armadilhas e formulações de grandlure para coleta do bicudo do algodoeiro. Pesquisa Agropecuária Brasileira, Brasília, v.22, n.9/10, p.917-921, 1987.

MICHELOTTO, M.D.; CHAGAS FILHO, N.R.; SILVA, R.A.; BUSOLI, A.C. Effect of diameter of the cotton squares in the development of boll weevil. Bragantia, Campinas, v.66, n. 1, p.97-100, 2007. 
MILANE, P.V.G.N.; CALDAS, F.M.; RIBEIRO, P.A.; FONTES E.M.G.; SUJII, E.R.; PIRES, C.S.S. Emergência do bicudo Anthonomus grandis em algodoeiro geneticamente modificado e convencional no cerrado de Brasília. In: CONGRESSO BRASILEIRO DE ENTOMOLOGIA, 22., 2008, Uberlândia, MG. Resumos. Uberlândia: SEB, 2008.

MIRANDA, J.E.; SILVA, C.A.D. Behavioural control of the cotton weevil, Anthonomus grandis (Coleoptera: Curculionidae), in Northeast Brazil. Boletín de Sanidad Vegetal. Plagas, Madrid, v.31, p.509-515, 2005.

MORALES, L.; CENA, P.; NETO, F.P.M.; COSTA, S.F.; OLIVEIRA, F.T. Resistência de genótipos de algodoeiro a Anthonomus grandis Boh., Frankliniella sp. e Aphis gossypii Glover. Anais da Sociedade Entomológica do Brasil, Londrina, v.26, n. 1, p.93-97, 1997.

MOREIRA, M.D.; SILVA, C.A.D.; LUCENA, I.; BELO, J.A.; MIRANDA, J.E. Controle climático do bicudo em algodoeiro colorido na região do Seridó paraibano. In: CONGRESSO BRASILEIRO DE ENTOMOLOGIA, 20., 2004, Gramado, RS. Resumos. Gramado: SEB, 2004. p.300.

MOREIRA, P.H.R.; SOARES, J.J.; BUSOLI, A.C.; CRUZ, V.R. da; PIMENTEL, M.H.L.; PELINSON, G.J.B. Causas do apodrecimento de maçãs do algodoeiro. Pesquisa Agropecuária Brasileira Brasília, v.29, n.10, p.1503-1507, 1994.

NAKANO, O. Níveis de controle de pragas. Cultivar Grandes Culturas, Pelotas, n.08, p.12-14, 1999.

NAKANO, O. Químio-esterilização contra bicudo. Cultivar Grandes Culturas, Pelotas, n.67, p.26-28, 2006.

NAKANO, O.; NIVOLONE, R.F.; VENDRAMINI, J.M.B.; CHATILA, C. Manejo de pragas do algodoeiro com o uso de fitoregulador. In: CONGRESSO BRASILEIRO DE ENTOMOLOGIA, 14., 1993 , Piracicaba, SP. Resumos. Piracicaba: SEB, 1993. p.576.

NAKANO, O.; PAPA, G.; ROCHELLE, L.A. Açoita cavalo - hospedeiro de Anthonomus spp, Boheman 1843 (Coleoptera: Curculionidae). In: CONGRESSO BRASILEIRO DE ENTOMOLOGIA, VII Encontro de Mimercologistas, I Encontro sobre moscas-das-frutas, 11, 1987, Campinas, SP. Resumos. Campinas: SEB, 1987. p.100.

NEVES, R.C.S.; PINTO JR., E.S.; BASTOS, C.S.; TORRES, J.B. Práticas culturais visando à redução populacional do bicudo do algodoeiro. In: CONGRESSO BRASILEIRO DE ENTOMOLOGIA, 23, 2010, Natal, RN. Resumos. Natal: SEB, 2010.

NEVES, R.C.S.; SHOWLER, A.T.; PINTO, E.S.; BASTOS, C.S.; TORRES, J.B. Reducing boll weevil populations by clipping terminal buds and removing abscised fruiting bodies. Entomologia Experimentalis et Applicata, v.146, n.2, p.276285, 2013.

NOBRE, S.D.N.; SUJII, E.R.; SCHIMIDT, F.G.V.; DIAS S.; LAUMAN, R.; OLIVEIRA NETO, O.B.; SÁ, M.F.G.; MONNERAT, R. Bionomy of the boll wevill reared on artificial diet. In: CONGRESSO BRASILEIRO DE ENTOMOLOGIA; CONGRESSO INTERNACIONAL DE ENTOMOLOGIA, 18., 2000, Foz do Iguaçu, PR. Resumos. Foz do Iguaçu: SEB, 2000. p.76.
NOGUEIRA, R.F.; MELO, E.P.; BARROS, R.; FERNANDES M.G.; DEGRANDE, P.E. Flutuação populacional do bicudodo-algodoeiro Anthonomus grandis Boheman, 1843 (Coleoptera: Curculionidae) e diferentes formas de aprisionamento dos insetos nas armadilhas de feromônio. In: CONGRESSO BRASILEIRO DE ALGODÃO, 5., 2005, Salvador, BA. Resumos. 2005.

NUNES, J.C.S.; FERNANDES, P.M. Parasitismo do bicudo do algodoeiro (Anthonomus grandis) em botões florais do algodoeiro, no município de Goiânia-GO. Pesquisa Agropecuária Tropical, v.30, n.2, p. 13-15, 2000.

OLIVEIRA, A.R.; DEGRANDE, P.E.; SANTOS, W.J.; MIRANDA, J.E.; SENHORELO, W.L.P.; SILVA, M.A.O.E. Efeitos do plano de controle do bicudo do algodoeiro (Anthonomus grandis) para a região sul do estado de Goiás. In: CONGRESSO BRASILEIRO DE ALGODÃO, 5., 2005. Salvador, BA. Resumos. 2005.

OLIVEIRA, C.D.; SIQUEIRA JR., J.P.; NAKAMURA, P.H.; SILVA, J.C. Pathogenicity of morphological mutants and wild-tips of Metarhizium anispliae (Metsch.) var. majus and minus against Anthonomus grandis Boheman. Anais da Sociedade Entomológica do Brasil, Londrina, v.23, n.3, p.425-430, 1994.

OLIVEIRA, C.G.A.; MIRANDA, J.E.; GARCIA, D.L.E. Supressão do bicudo do algodoeiro (Anthonomus grandis) no estado de Goiás. In: CONGRESSO BRASILEIRO DE ALGODÃO, 8.; COTTON EXPO, 1., 2011 , São Paulo, SP. Evolução da cadeia para construção de um setor forte: Anais. Campina Grande, PB: Embrapa Algodão, 2011 . p.266.

OLIVEIRA, G.S.; AQUINO, I.S. RAMALHO, F.S.; LEMOS, W.P. Efeitos de tipos de filmes de PVC na reprodução de Catolaccus grandis (Burks) (Hymenoptera: Pteromalidae) parasitoide do bicudo do algodoeiro, Anthonomus grandis Boheman (Coleoptera: Curculionidae). Revista Brasileira de Oleaginosas e Fibrosas, Campina Grande, v.7, n.2/3, p.699$708,2003$.

OLIVEIRA NETO, O.B.; BATISTA, J.A.N.; FRAGOSO, R.R.; DIAS S.C.; MONNERAT, R.; SÁ, M.F.G. Characterization of the proteolytic activity of Anthonomus grandis and isolation of CDNAs encoding serine and cysteine protease. In: CONGRESSO BRASILEIRO DEENTOMOLOGIA/CONGRESSO INTERNACIONAL DE ENTOMOLOGIA, 18., 2000, Foz do Iguaçu, PR. Resumos. Foz do Iguaçu: SEB, 2000. p.535.

PAPA, G.; NAKANO, O.; OISHI, W.K. Controle do "bicudo do algodoeiro", Anthonomus grandis (BOHEMAN, 1843) (Coleoptera, Curculionidae), com o emprego do feromônio de agregação "Blockaide". In: CONGRESSO BRASILEIRO DE ENTOMOLOGIA, 9., 1984, Londrina, PR. Resumos. Londrina: SEB, 1984. p.216.

PARON, M.R.; BUSOLI, A.C.; CRISPOLIM, F.A.; DIBELLI, W. Dinâmica populacional de Anthonomus grandis Boheman, (Coleoptera: Curculionidae) na safra e entressafra em área de algodão na região de Jaboticabal, SP. In: CONGRESSO BRASILEIRO DE ENTOMOLOGIA, 14., 1993, Piracicaba, SP. Resumos. Piracicaba: SEB, 1993a. p.164. 
PARON, M.R.; BUSOLI, A.C.; MACARI, M.; SECATO, E.R.; GUERREIRO, J.R. Determinação do teor de lipídios em Anthonomus grandis Boheman, (Coleoptera: Curculionidae) pela técnica de "dosagem de lipídio total". In: CONGRESSO BRASILEIRO DE ENTOMOLOGIA, 14., 1993, Piracicaba, SP. Resumos. Piracicaba: SEB, 1993b. p. 195.

PARON, M.R.; BUSOLI, A.C.; MACARI, M.; GUERREIRO, J.R.; SECATO, E.R. Determinação do teor de lipídios em Anthonomus grandis Boh. (Coleoptera: Curculionidae) pelo método "dosagem de lipídio total", na safra e entressafra do algodoeiro. Anais da Sociedade Entomológica do Brasil, n.24, v.2, p.323-328, 1995

PAULA, D.P.; CLAUDINO, D.; TIMBO, R.V.; MIRANDA, J. E. BEMQUERER, M.P.; RIBEIRO, A.C.; SUJII, E.R.; FONTES, E.M.; PIRES, C.S. Reproductive dormancy in boll-weevil from populations of the Midwest of Brazil. Journal of Economic Entomology, Annapolis, v. 106, n. 1, p.86-89, 2013.

PESSOA, M.C.P.Y.; MEYER, J.F.C.A; FERNANDES, J.F.R.; PIEROZZI JR, I.; HABIB, M.E.M. A interação bicudo-algodoeiro: modelagem matemática e manejo integrado. In: CONGRESSO BRASILEIRO DE ENTOMOLOGIA, 14., 1993, Piracicaba, SP. Resumos. Piracicaba: SEB, 1993b. p.658.

PESSOA, M.C.P.Y.; PIEROZZI JR, I.; HABIB, M.E.M. Sistema especialista para identificação de fatores de mortalidade natural dos estágios imaturos do bicudo do algodoeiro, na região de Campinas, SP. In: CONGRESSO BRASILEIRO DE ENTOMOLOGIA, 14., 1993, Piracicaba, SP. Resumos. Piracicaba: SEB, 1993a. p.233.

PIEROZZI JR., I.; HABIB, M.E.M; ANDRADE, C.F.S. Ocorrência natural de parasitismo e predação em população do bicudo, Anthonomus grandis BOHEMAN, 1843. In: CONGRESSO BRASILEIRO DE ENTOMOLOGIA, 9., 1984, Londrina, PR. Resumos. Londrina: SEB, 1984. p. 163

PIEROZZI JR., I.; HABIB, M.E.M. Primeiro registro de parasitismo em adultos de Anthonomus grandis Boh. (Coleoptera, Curculionidae) por Hyalomyodes brasiliensis Tow. (Diptera: Tachinidae). In: CONGRESSO BRASILEIRO DE ENTOMOLOGIA, 10., 1986, Rio de Janeiro, RJ. Resumos. Londrina: SEB, 1986. p.241.

PIEROZZI JR., I.; HABIB, M.E.M. Proposta e análise de componentes básicos para um programa de M.I.P. para algodoais infestados por Anthonomus grandis Boheman, 1843 (Coleoptera: Curculionidae), na região de CampinasSP. Revista de Agricultura, Piracicaba, v.67, n.3, p.252267, 1992.

PIEROZZI JR., I.; HABIB, M.E.M. Componentes básicos de um programa de M.I.P. para algodoais infestados pelo bicudo na região Sudeste do estado de São Paulo. In: CONGRESSO BRASILEIRO DE ENTOMOLOGIA, 14., 1993, Piracicaba, SP. Resumos. Piracicaba: SEB, 1993b. p.572.

PIEROZZI JR., I.; HABIB, M.E.M. Identificação de fatores de mortalidade natural dos estágios imaturos de Anthonomus grandis Boh. (Coleoptera: Curculionidae), na região de Campinas, SP. Anais da Sociedade Entomológica do Brasil, v.22, n.2. p.325-332, 1993a.
PIEROZZI JR., I.; HABIB, M.E.M. Aspectos biológicos e de comportamento dos principais parasitos de Anthonomus grandis Boh. (Coleoptera: Curculionidae), em Campinas, SP. Anais da Sociedade Entomológica do Brasil, v.22, n.2. p.317-323, 1993b.

PIPOLO, A.E.; ATHAYDE, M.L.F.; PIPOLO, V.C. Utilização do cloreto de clorocolina no controle do bicudo-do-algodoeiro. Pesquisa Agropecuária Brasileira, Brasília, v.33, n.7, p.106777, 1998.

PIRES, M.P.; DEGRANDE, P.E.; SANTOS, W.J.; MIRANDA, J.E.; SENHORELO, W.L.P.; SILVA, M.A.O.E. Aplicação do plano estratégico de controle do bicudo-do-algodoeiro (Anthonomus grandis) na região de Inaciolândia, Goiás. In: CONGRESSO BRASILEIRO DE ALGODÃO. 5., 2005, Salvador, BA. Resumos. 2005.

PRAÇA, L.B.; BATISTA, A.C.; MARTINS, E.S.; SIQUEIRA, C.B.; DIAS, D.G.S.; GOMES, A.C.M.M.; FALCÃO, R.; MONNERAT, R.G. Estirpes de Bacillus thuringiensis efetivas contra insetos das ordens Lepidoptera, Coleoptera e Diptera. Pesquisa Agropecuária Brasileira, Brasília, v.39, n.1, p.11-16, 2004.

RAMALHO, F.S.; GONZAGA, J.V.; SILVA, J.R.B. Método para determinação das causas de mortalidade natural do bicudo-doalgodoeiro. Pesquisa Agropecuária Brasileira, Brasília, v.28, n.8, p.877-887, 1993b.

RAMALHO, F.S.; GONZAGA, J.V. Efeito do substrato alimentar no peso, gordura e órgãos reprodutivos do bicudo do algodoeiro, Anthonomus grandis (Coleoptera: Curculionidae). In: CONGRESSO BRASILEIRO DE ENTOMOLOGIA, II Encontro sobre moscas-das-frutas, 12., 1989, Belo Horizonte, MG. Resumos. Belo Horizonte: SEB, 1989a. p.12.

RAMALHO, F.S.; GONZAGA, J.V. Efeito do consórcio algodão com milho e inseticida na população do bicudo do algodoeiro, Anthonomus grandis Boheman (Coleoptera: Curculionidae). In: CONGRESSO BRASILEIRO DE ENTOMOLOGIA, II Encontro sobre moscas-das-frutas, 12., 1989, Belo Horizonte, MG. Resumos. Belo Horizonte: SEB, 1989b. p.412.

RAMALHO, F.S.; GONZAGA, J.V. Efeitos do consórcio de algodão com milho e piretróide contra o bicudo-do-algodoeiro. Pesquisa Agropecuária Brasileira, Brasília, DF, v.25, n.2, p.191199, 1990.

RAMALHO, F.S.; JESUS, F.M.M. Locais de oviposição e alimentação do bicudo do algodoeiro Anthonomus grandis nas plantas. In: CONGRESSO BRASILEIRO DE ENTOMOLOGIA, VII Encontro de Mimercologistas, I Encontro sobre moscas-dasfrutas, 11., 1987, Campinas, SP. Resumos. Campinas: SEB, 1987a. p. 102.

RAMALHO, F.S.; JESUS, F.M.M. Atividade fisiológica do bicudo do algodoeiro Anthonomus grandis nos períodos de safra e entressafra. In: CONGRESSO BRASILEIRO DE ENTOMOLOGIA, VII Encontro de Mimercologistas, I Encontro sobre moscasdas-frutas, 11, 1987, Campinas, SP. Resumos. Campinas: SEB, 1987b. p.103.

RAMALHO, F.S.; JESUS, F.M.M.; GONZAGA, J.V. Táticas de manejo integrado de pragas em áreas infestadas pelo bicudodo-algodoeiro. Pesquisa Agropecuária Brasileira, Brasília, v.25, n.5, p.677-690, 1990. 
RAMALHO, F.S.; JUSSELINO FILHO, P.; SILVA, J.R.B. Tabela de vida ecológica do bicudo-do-algodoeiro, Anthonomus grandis Boheman. In: CONGRESSO BRASILEIRO DE ENTOMOLOGIA, 14., 1993, Piracicaba, SP. Resumos. Piracicaba: SEB, 1993a. p.242.

RAMALHO, F.S.; SILVA, J.R.B. Período de emergência e mortalidade natural do bicudo-do-algodoeiro. Pesquisa Agropecuária Brasileira, Brasília, v.28, n.11, p.1221$1231,1993$.

RAMALHO, F.S.; SILVA, G.F.da; OLIVEIRA, G.S.; SILVA, J.P.S.; BANDEIRA, C.M.; MALAQUIAS, J.B.; PEREIRA, A.I.A. Parasitism by Catolaccus grandis (Burks) (Hymenoptera: Pteromalidae) after inundative releases against the cotton boll weevil. In: CONGRESSO BRASILEIRO DE ENTOMOLOGIA, 21., 2006, Recife, PE. Resumos. Recife: SEB, 2006.

RAMALHO, F.S.; SILVA, J.R.B.; JUSSELINO FILHO, P. Efeito da densidade de botão floral e temperatura na oviposição e alimentação do Anthonomus grandis Boheman. In: CONGRESSO BRASILEIRO DE ENTOMOLOGIA, 14., 1993c, Piracicaba, SP. Resumos. Piracicaba: SEB, 1993b. p.222.

RAMALHO, F.S. Comportamento de alimentação e oviposição do bicudo-do-algodoeiro em relação a densidade de botão floral e temperatura. Anais da Sociedade Entomológica do Brasil, Londrina, v.24, n.3, p.533-541, 1995.

RAMALHO, F.S.; WANDERLEY, P.A.; MALAQUIAS, J.B.; FERNANDES, F.S.; NASCIMENTO, A.R.B.; ZANUNCIO, J.C. Effect of temperature on the reproduction of Bracon vulgaris Ashmead (Hymenoptera: Braconidae), a parasitoid of the cotton boll weevil. Anais da Academia Brasileira Ciências, Rio de Janeiro, v.83, n.3, p.1021-1030, 2011.

RAMALHO, F.S.; WANDERLEY, P.A.; MEZZOMO, J.A. Influência da temperatura na fecundidade e ataque de Catolaccus grandis (Burks) (Hymenoptera, Pteromalidae), parasitoide do bicudodo-algodoeiro, Anthonomus grandis Boheman (Coleoptera, Curculionidae). Revista Brasileira de Entomologia, São Paulo, v.42, n.1/2, p.71-72, 1998.

RAMIRO, Z.A.; CARDOSO, A.M.; FERREIRA, A.; CONCEIÇÃO, C.H.C.; MUNHOZ, S.; AJUDARTE, J.C. Levantamento de adultos do bicudo Anthonomus grandis nas estruturas florais do algodoeiro, no período das 8:00 às 18:00 horas. In: CONGRESSO BRASILEIRO DE ENTOMOLOGIA, 16., 1997, Salvador, BA. Resumos. Salvador: SEB/Embrapa-CNPMF, 1997. p.306.

RAMIRO, Z.A.; NOVO, J.P.S.; TANCINI, R.S. Flutuação dos danos ocasionados pelo "bicudo" do algodoeiro, Anthonomus grandis Boheman, 1843, no município de Artur Nogueira. Biológico, São Paulo, v.55, n.1/2, p.19-21, 1989.

REZENDE, A.M.; MIRANDA, J.E.; LABOISSÍERE, D.; LIMBERTE, R. Redução populacional do bicudo do algodoeiro (Anthonomus grandis) ao adotar o plano estratégico de controle. In: CONGRESSO BRASILEIRO DE ALGODÃO, 8; COTTON EXPO, 1, 2011 , São Paulo, SP. Evolução da cadeia para construção de um setor forte: Anais. Campina Grande, PB: Embrapa Algodão, 2011 . p.256.
RIBEIRO, J.F.; SANCHEZ, G.A.; AARÃO, F.;. FONSECA, P.R.B.; NOGUEIRA, R.F.; DEGRANDE, P.E. Monitoramento e controle do bicudo-do-algodoeiro (Anthonomus grandis Boheman, 1843) na região sul do estado de São Paulo. In: CONGRESSO BRASILEIRO DE ALGODÃO, 5., 2005, Salvador, BA. Resumos. 2005b.

RIBEIRO, P.A.; FONTES G.E.M; FRIZZAS, M.R.; DINIZ, I.R.; SUJII, E.R.; ORTIS, G.S. Amostragens de populações do bicudo-do-algodoeiro Anthonomus grandis em plantio de algodão e áreas de vegetação natural no cerrado do Brasil central. In: CONGRESSO BRASILEIRO DE ENTOMOLOGIA, 20., 2004, Gramado, RS. Resumos. Gramado: SEB, 2004. p.419.

RIBEIRO, P.A.; DINIZ, I.R.; FONTES, E.M.G. SUJII, E.R.; PIRES, C.S.S.; SILVA, I.S.; SILVA, K.F.AS.; MOTA, V.A. Estratégia de sobrevivência do bicudo-do-algodoeiro Anthonomus grandis na entressafra do algodão no cerrado de Brasília. In: CONGRESSO BRASILEIRO DE ENTOMOLOGIA, 21., 2006, Recife, PE. Resumos. Recife: SEB, 2006a.

RIBEIRO, P.A.; DINIZ, I.R.; FONTES, E.M.G. SUJII, E.R.; PIRES, C.S.S.; SANTOS, P.H.R.; MACEDO, T.R.; TOGNI, P.H.B. Movimentação e refúgios utilizados pelo bicudo-doalgodoeiro Anthonomus grandis na entressafra da cultura do algodão no cerrado de Brasília. In: CONGRESSO BRASILEIRO DE ENTOMOLOGIA, 21., 2006, Recife, PE. Resumos. Recife: SEB, 2006b.

RIBEIRO, P.A.; DINIZ, I.R.; SUJII, E.R.; FONTES, E.M.G. Infestação do bicudo-do-algodoeiro Anthonomus grandis em plantio de algodão no cerrado do Brasil central. In: CONGRESSO BRASILEIRO DE ALGODÃO, 5., 2005, Salvador, BA. Resumos. 2005a.

RIBEIRO, P.A.; SUJII, E.R.; DINIZ, I.R.; MEDEIROS, M.A.; SALGADOLABOURIAU, M.L.; BRANCO, M.C.; PIRES, C.S.S.; FONTES, E.M.G. Alternative food sources and overwintering feeding behavior of the boll weevil, Anthonomus grandis Boheman (Coleoptera: Curculionidae) under the tropical conditions of central Brazil. Neotropical Entomology, v.39, n. 1, p.28-34, 2010.

RODRIGUES, S.; MIRANDA, E. Monitoramento do bicudo em algodão. Cultivar Grandes Culturas, Pelotas, n.98, p.28-30, 2007.

RODRIGUES, S.M.M.; MENEZES, V.L.; KAMINSKI, E. Flutuação populacional do bicudo-do-algodoeiro em áreas de refúgio na entressafra. In: CONGRESSO BRASILEIRO DE ALGODÃO, 8., \& COTTON EXPO, 1., 2011 , São Paulo, SP. Anais. Campina Grande, PB: Embrapa Algodão, 2011 . p.196.

RODRIGUES, S.M.M.; MIRANDA, J.E.; MENEZES, V.L. Influência da presença do Tubo Mata-Bicudo (TMB ${ }^{\circ}$ ) na captura de bicudo do algodoeiro em armadilhas. In: CONGRESSO BRASILEIRO DE ENTOMOLOGIA, 22., 2008, Uberlândia, MG. Resumos. Uberlândia: SEB, 2008.

SÁ, M.F.G.; SILVA, M.C.; BRUNETTA, P.; OLIVEIRA G.; FILGUEIRA, E.L.Z. Toxinas Cry e sua aplicação no controle do bicudo do algodoeiro (Anthonomus grandis). In: CONGRESSO BRASILEIRO DE ENTOMOLOGIA, 20., 2004, Gramado, RS. Resumos. Gramado: SEB, 2004. p. 145. 
SANTOS, A.F.; DEGRANDE, P.E.; SANTOS, W.J.; MIRANDA J.E.; SENHORELO, W.L.P.; SILVA, M.A.O.E. Aplicação do plano de controle de bicudo nas duas últimas safras na região de Acreúna, Goiás. In: CONGRESSO BRASILEIRO DE ALGODÃO, 5., 2005, Salvador, BA. Resumos. Salvador: 2005.

SANTOS, B.B. Alguns artrópodes associados ao algodoeiro no estado do Paraná. In: CONGRESSO BRASILEIRO DE ENTOMOLOGIA, 12., ENCONTRO SOBRE MOSCAS-DASFRUTAS, 2., 1989, Belo Horizonte, MG. Resumos. Belo Horizonte: SEB, 1989. p. 165.

SANTOS, R.C. Cultivar com resistência ao bicudo. Cultivar Grandes Culturas, Pelotas, n.66, p.6-9, 2004

SANTOS, R.C.; MARCELLINO, L.H.; MONNERAT, R.G.; GANDER, E.S. Mechanical damage in cotton buds caused by the boll weevil. Pesquisa Agropecuária Brasileira, Brasília, v.38, n.11, p.1351-1356, 2003

SANTOS, R.C.; MONNERAT, R.G.; SÁ, M.F.G.; CORDEIRO, C.M.T.; GOMES, A.C.; GANDER, E.S. Cholesterol oxidase interference on the emergence and viability of cotton boll weevil larvae. Pesquisa Agropecuária Brasileira, Brasília, v.37, n. 11, p.15251530, 2002

SANTOS, R.C.; RAMIRO, Z.A.; CORREIA, M.F.M. Avaliação do nível de controle recomendado para o bicudo do algodoeiro, Anthonomus grandis BOHEMAN, 1843 (Coleoptera, Curculionidae). In: CONGRESSO BRASILEIRODEENTOMOLOGIA 13., \& SIMPÓSIO INTERNACIONAL SOBRE BICUDO DO ALGODOEIRO, 1., ENCONTRO SOBRE "COCHONILHA" DA PALMA FORRAGEIRA, 2., ENCONTRO SOBRE MOSCAS-DASFRUTAS, 3., 1991, Recife, PE. Resumos. Londrina: SEB, 1991. p.573.

SANTOS, W.J. Eficiência de controle do bicudo do algodoeiro, Anthonomus grandis, através da aplicação de gotas contendo a mistura de feromônio sexual "Grandlure" e cipermetrina. In: CONGRESSO BRASILEIRO DE ENTOMOLOGIA, 16., 1997, Salvador, BA. Resumos. Salvador: SEB/Embrapa-CNPMF, 1997. p.298.

SANTOS, W.J. Sintomas de ataque do bicudo, Anthonomus grandis Boh., 1843, em plantas jovens, como sinalizadores das rotas de imigração da praga na lavoura de algodão. In: CONGRESSO BRASILEIRO DE ENTOMOLOGIA, 14., 1993, Piracicaba, SP. Resumos. Piracicaba: SEB, 1993. p.38.

SANTOS, W.J. Use of the pheromone traps "grandlure" for attraction and control of the boll weevil, Anthonomus grandis in cotton. In: CONGRESSO BRASILEIRO DE ENTOMOLOGIA, 20. 2004, Gramado, RS. Resumos. Gramado: SEB, 2004. p.710.

SANTOS, W.J. Bicudo e brocas no algodão. Cultivar Grandes Culturas, Pelotas, n.36, p.12-16, 2002.

SCARPELLINI, J.R.; BUSOLI, A.C. Infestação do bicudo do algodoeiro, Anthonomus grandis Boheman, 1843 (Coleoptera: Curculionidae) correlacionada a queda de botões florais em cultivares de algodoeiro. Arquivos do Instituto Biológico, v.66, n. 1, p.69-76, 1999.
SCARPELLINI, J.R.; RAMIRO, Z.A. Avaliação dos danos ocasionados pelo bicudo do algodoeiro, Anthonomus grandis, em áreas com e sem tubos mata bicudo (TMB). In: CONGRESSO BRASILEIRO DE ENTOMOLOGIA, 16., 1997, Salvador, BA. Resumos. Salvador: SEB/Embrapa-CNPMF, 1997. p.306.

SCOMPARIN, A.L.X.; FELÍCIO, R.S.; OLIVEIRA, E. Identificação de plantas hospedeiras do bicudo do algodoeiro no Cerrado. In: CONGRESSO BRASILEIRO DE ALGODÃO. 5., 2005, Salvador, BA. Resumos. 2005a.

SCOMPARIN, A.L.X.; FELÍCIO, R.S.; OLIVEIRA, E. Dinâmica populacional do bicudo do algodoeiro na região de ItiquiraMT. In: CONGRESSO BRASILEIRO DE ALGODÃO, 5., 2005, Salvador, BA. Resumos. 2005b.

SILVA, A.L.; DEGRANDE, P.E.; SANTOS, W.J.; MIRANDA, J.E.; SENHORELO, W.L.P.; SILVA, M.A.O.E. Aplicação do plano de controle do bicudo do algodoeiro (Anthonomus grandis) na região de Paraúna-Go. In: CONGRESSO BRASILEIRO DE ALGODÃO, 5., 2005, Salvador, BA. Resumos. 2005b.

SILVA, C.A. Algodão colorido. Cultivar Grandes Culturas, Pelotas, n. 143, p. $12,2011$.

SILVA, C.A. Supressão do bicudo em algodoeiro. Cultivar Grandes Culturas, Pelotas, n. 154, p.8-9, 2012.

SILVA, C.A.D. Seleção de isolados de Beauveria bassiana patogênicos ao bicudo-do-algodoeiro. Pesquisa Agropecuária Brasileira, Brasília, v.36, n.2, p.243-247, 2001.

SILVA, C.A.D.; MIRANDA, J. E.; MOREIRA, M.; SILVA, T.D.U. da. Efeito de agentes bio-controladores do bicudo Anthonomus grandis (Coleoptera: Curculionidae) no cultivo do algodão colorido. In: CONGRESSO BRASILEIRO DE ALGODÃO, 4., 2003, Goiânia, GO. Anais. Goiânia, 2003.

SILVA, C.A.D da; MIRANDA, J. E.; SOUZA JÚNIOR, J.D.A. de; SILVA, T.D.U. da. Efeito de diferentes concentrações de óleos vegetais na formulação de suspensões de conídios de Beauveria Bassiana visando o controle do bicudo Anthonomus grandis. In: IV CONGRESSO BRASILEIRO DE ALGODÃO, 2003b, Goiânia, GO. Anais, 2003.

SILVA, C.A.D.; SOUSA, S.L.; SOUSA Jr., D.V.; VIANA, D.L. Eficiência da catação de botões florais caídos ao solo e de pulverizações com caolim misturado ao fungo B. bassiana contra o bicudo do algodoeiro. In: CONGRESSO BRASILEIRO DE ALGODÃO, 7., 2009, Foz do Iguaçu, PR. Anais. Campina Grande: Embrapa Algodão, 2009a. p.724-729.

SILVA, C.A.D. da; RAMALHO, F.S. de; SOUSA, S.L. de; VIANA, D. de L.; SOUSA JUNIOR, D.V. de. Eficiência de pulverizações com caolim contra o bicudo do algodoeiro. In: CONGRESSO BRASILEIRO DE ALGODÃO, 7., 2009, Foz do Iguaçu, PR. Anais. Campina Grande: Embrapa Algodão, 2009b. p.401-405.

SILVA FILHO, N.L.; CHAIB, S.L. Monitoramento do "bicudo-doalgodoeiro" (Anthonomus grandis, Boheman 1843) na reserva biológica de Mogi Guaçu-SP. In: CONGRESSO BRASILEIRO DE ENTOMOLOGIA 11., ENCONTRO DE MIMERCOLOGISTAS, 7., ENCONTRO SOBRE MOSCAS-DAS-FRUTAS, 1., 1987, Campinas, SP. Resumos. Campinas: SEB, 1987. p.104. 
SILVA, F.P.; BEZERRA, A.P.L.; SILVA, A.F.. Oviposição e alimentação do bicudo, Anthonomus grandis Boheman, em linhagens mutantes de algodoeiro herbáceo de cultura de soca. Revista Ciência Agronômica, Fortaleza, v.39, n. 1, p.85-89, 2008.

SILVA, I.A.M.; DEGRANDE, P.E.; SANTOS, W.J.; MIRANDA, J.E.; SENHORELO, W.L.P.; SILVA, M.A. de O.E. Adesão do plano de controle de bicudo nas três últimas safras na região de Mineiros-GO. In: CONGRESSO BRASILEIRO DE ALGODÃO, 5., 2005, Salvador, BA. Resumos. Salvador, $2005 a$.

SILVA, M.A.O.E.; DEGRANDE, P.E.; SANTOS, W.J.; MIRANDA, J.E.; SENHORELO, W.L.P. Nível de adesão ao plano estratégico de controle do bicudo-do-algodoeiro (Anthonomus grandis) em diferentes propriedades na região de Ipameri, Goiás. In: CONGRESSO BRASILEIRO DE ALGODÃO, 5., 2005, Salvador, BA. Resumos. Salvador, 2005e.

SILVA, M.A.O.E.; DEGRANDE, P.E.; SANTOS, W.J.; MIRANDA, J.E.; SENHORELO, W.L.P. Resultados da aplicação do plano estratégico de controle do bicudo-do-algodoeiro (Anthonomus grandis) na região de Ipameri, Goiás. In: CONGRESSO BRASILEIRO DE ALGODÃO, 5., 2005, Salvador, BA. Resumos. Salvador, $2005 \mathrm{f}$.

SILVA, M.S.; SOARES, J.J.; MELO, R.S.; FERREIRA, A.M.C. Influência de cultivar e época de plantio no manejo de insetos associados ao algodoeiro. In: CONGRESSO BRASILEIRO DE ENTOMOLOGIA, 20., 2004, Gramado, RS. Resumos. Gramado: SEB, 2004. p.545.

SILVA, M.S.; SOARES, J.J.; SANTOS, J.W.; ARAÚJO, L.H.A. Efeito da época de plantio nas populações de Bemisia argentifolli e Anthonomus grandis. In: CONGRESSO BRASILEIRO DE ENTOMOLOGIA, 19., 2002, Manaus, AM. Resumos. Manaus: INPA/SEB, 2002. p.289.

SILVA, T.N.E; DEGRANDE, P.E.; SANTOS, W.J.; MIRANDA, J.E.; SENHORELO, W.L.P.; SILVA, M.A. de O.E. Comparativo de áreas com diferentes níveis de adesão ao plano estratégico de controle do bicudo-do-algodoeiro na região de Santa Helena de Goiás. In: CONGRESSO BRASILEIRO DE ALGODÃO, 5., 2005, Salvador, BA. Resumos. Salvador, 2005c.

SILVA, T.N.E; DEGRANDE, P.E.; SANTOS, W.J. dos; MIRANDA, J.E.; SENHORELO, W.L.P.; SILVA, M.A. de O.E. Plano de controle do bicudo do algodoeiro desde sua instalação na safra 2002/2003 na região de Santa Helena de Goiás. In: CONGRESSO BRASILEIRO DE ALGODÃO, 5., 2005, Salvador, BA. Resumos. Salvador, 2005d.

SILVA, T.N.E; PIRES, M.P.; MIRANDA, J.E.; SILVA, M.A.O.S. Eficiência de feromônios de atração sexual na captura do bicudo do algodoeiro. In: CONGRESSO BRASILEIRO DE ENTOMOLOGIA, 21., 2006, Recife, PE. Resumos. Recife: SEB, 2006.

SILVEIRA NETO, S.; AMBROZANO, C.M.B. Avaliação da densidade populacional do bicudo Anthonomus grandis Boh., no início do ciclo do algodão. In: CONGRESSO BRASILEIRO DE ENTOMOLOGIA, 11., ENCONTRO DE MIMERCOLOGISTAS, 7., ENCONTRO SOBRE MOSCAS-DASFRUTAS, 1., 1987, Campinas, SP. Resumos. Campinas: SEB, 1987. p. 105.
SILVIE, P.J.; RENOU, A.; BADJI, C.A. Controle das pragas do algodão por práticas culturais e manipulação do habitat. Revista Brasileira de Oleaginosas e Fibrosas, Campina Grande, v.10, n.3, p.1183-1196, 2006.

SOARES, J.J. Efeito de diversas táticas de controle do bicudo e suas interferências no manejo integrado de pragas do algodoeiro. In: CONGRESSO BRASILEIRO DE ENTOMOLOGIA, 17., 1998, Rio de Janeiro, RJ. Resumos. Rio de Janeiro: SEB, 1998. p.543.

SOARES, J.J.; ALMEIDA, R.P.; YAMAMOTO, P.T.; CRISPOLIM, F.A. Influência de táticas de pós-colheita na captura de bicudo Anthonomus grandis Boheman, 1843 (Coleoptera, Curculionidae). In: CONGRESSO BRASILEIRO DE ENTOMOLOGIA, 14., 1993, Piracicaba, SP. Resumos. Piracicaba: SEB, 1993. p.570.

SOARES, J.J.; ARAÚJO, A.D. Influência da época de plantio e do ataque do bicudo Anthonomus grandis (Coleoptera: Curculionidae) sobre a abscisão de botões e maçãs de algodoeiro. Anais da Sociedade Entomológica do Brasil, Londrina, v.22, n.2, p.251-257, 1993.

SOARES, J.J.; BUSOLI, A.C. Efeito dos reguladores de crescimento vegetal nas características agronômicas do algodoeiro e no controle de insetos. Pesquisa Agropecuária Brasileira, Brasília, v.31, n. 1, p.37-41, 1996.

SOARES, J.J.; BUSOLI, A.C.; LARA, F.M.; FURCIM, J.L. Influência de fitorreguladores na antecipação e uniformização da abertura das maçãs do algodoeiro e no controle de Anthonomus grandis Boh. Anais da Sociedade Entomológica do Brasil, Londrina, v.24, n. 1, p.7-11, 1995.

SOARES, J.J.; BUSOLI, A.C.; YAMAMOTO, P.T.; BRAGA SOBRINHO, R. Efeito de práticas culturais de pós-colheita sobre populações do bicudo-do-algodoeiro, Anthonomus grandis Boheman, 1843. Pesquisa Agropecuária Brasileira, Brasília, v.29, n.3, p.375-379, 1994.

SOARES, J.J.; CARVALHO, O.S.; MOULIM, M.C.; SILVA. M.S.; ALENCAR, A.R. de. Validação de um sistema de Manejo Integrado de Pragas para o Oeste da Bahia. In: CONGRESSO BRASILEIRO DE ENTOMOLOGIA, 19., 2002, Manaus, AM. Resumos. Manaus: INPA/SEB, 2002. p.289.

SOARES, J.J.; LARA, F.M. Resistência do algodoeiro herbáceo a Anthonomus grandis Boheman, 1843 (Coleoptera: Curculionidae) e interação com inseticida. Pesquisa Agropecuária Brasileira, v.28, n.10, p.1129-1135, 1993 a.

SOARES, J.J.; LARA, F.M. Não-preferência para alimentação e oviposição de Anthonomus grandis Boheman, 1843 por diferentes genótipos de algodoeiro. Científica, São Paulo, v.21, n.2, p.333-338, 1993b.

SOARES, J.J.; LARA, F.M. Influência de genótipos de algodoeiro no nível de parasitismo de Anthonomus grandis Boh. por Bracon mellitor Say. Anais da sociedade Entomológica do Brasil, n.22, n.3, p.541-545, 1993 c.

SOARES, J.J.; LARA, F.M.; CARVALHO, L.P. Uso de algodão resistente. Cultivar Grandes Culturas, Pelotas, n.8, p.1618, 1999. 
SOARES, J.J.; SILVA, M.S. Efeito da época de plantio na produção e na ocorrência de pragas em culturas do algodoeiro (Gossypium hirsutum). Arquivos do Instituto Biológico, São Paulo, v.70, n.3, p.295-302, 2003.

SOARES, J.J.; YAMAMOTO, P.T. Comportamento de oviposição de Anthonomus grandis Boheman, 1843 (Coleoptera, Curculionidae) em diferentes níveis de infestação natural. In: CONGRESSO BRASILEIRO DE ENTOMOLOGIA, 14., 1993, Piracicaba, SP. Resumos. Piracicaba: SEB, 1993a. p.87.

SOARES, J.J.; YAMAMOTO, P.T. Comportamento de oviposição de Anthonomus grandis Boheman, 1843 (Coleoptera, Curculionidae) em diferentes níveis de infestação natural. Anais da Sociedade Entomológica do Brasil, Londrina, v. 22, n.2, p.333-339, 1993b.

SOARES, M.M.M.; FARIAS, A.M.I.; FERNANDES, A.M.V. Estudo sobre preferência por oviposição e alimentação do bicudo do algodoeiro Anthonomus grandis Boheman, 1843 (Coleoptera, Curculionidae) por diferentes cultivares comerciais de algodão herbáceo Gossypium hirsutum L. R. Iatifolium Huth, 1758. In: CONGRESSO BRASILEIRO DE ENTOMOLOGIA, 17., 1998, Rio de Janeiro, RJ. Resumos. Rio de Janeiro: SEB, 1998. p.610.

TAMAI, M.A.; CARVALHO, E.; BREDA, C.; TIAGO, P.C.M. Programa fitossanitário para o monitoramento e controle do bicudo no oeste da Bahia. In: CONGRESSO BRASILEIRO DE ALGODÃO, 7., 2009, Foz do Iguaçu, PR. Anais. Campina Grande: Embrapa Algodão, 2009. p.339-347.

TOMQUELSKI, G.V.; MARTINS, G.M. Bicudo em algodão. Cultivar Grandes Culturas, Pelotas, n.111, p.42-45, 2008.

THOMAZINI, M.J.; SOARES, J.J. Abundância estacional de parasitoides associados ao bicudo do algodoeiro Anthonomus grandis Boheman, 1843. In: CONGRESSO BRASILEIRO DE ENTOMOLOGIA, 14., 1993, Piracicaba, SP. Resumos. Piracicaba: SEB, 1993. p.133.

THOMAZONI, D.; ALVES, L.F.A.; PIRES, E.; PIERRE J.; SILVIE, P.J.; SANTOS, J.C. Seleção de isolados de fungos entomopatogênicos (Beauveria bassiana e Metarhizium anisopliae) visando o controle do bicudo-do-algodoeiro (Anthonomus grandis, Boheman 1843) (Coleoptera: Curculionidae). In: CONGRESSO BRASILEIRO DE ALGODÃO, 5., 2005, Salvador, BA. Resumos. Salvador, 2005.

VÊLOSO, J.M. Comparações morfológicas entre Anthonomus grandis Boheman, 1843 (Coleoptera: Curculionidae), "bicudo do algodoeiro" e outros curculionídeos. In: CONGRESSO BRASILEIRO DE ENTOMOLOGIA, 11., ENCONTRO DE MIMERCOLOGISTAS, 7. ENCONTRO SOBRE MOSCAS-DAS-FRUTAS, 1., 1987, Campinas, SP. Resumos. Campinas: SEB, 1987. p.479.

VIDAL, J.; MATA, R.A.; CHAGAS, G.A.; VENZON, M.; PIRES, C.S.S.; SUJII, E.R.; FONTES, E.M.G.; BRAVO, L.K.B. Seleção de espécies como armadilha para o controle do bicudo do algodoeiro: o quiabo é um forte candidato. In: CONGRESSO BRASILEIRO DE ENTOMOLOGIA, 23., 2010, Natal, RN. Resumos. Natal: SEB, 2010.

VIDAL NETO, F.C.; SILVA, F.P.; BLEICHER, E.; MELO, F.I.O. Mutantes morfológicos de algodoeiro herbáceo como fonte de resistência ao bicudo. Pesquisa Agropecuária Brasileira, Brasília, v.40, n.2, p. 123-128, 2005.

VIEIRA, F.V.; SANTOS, J.H.R.; ALVES, J.N.; LIMA, I.T.; CASTRO, P.E.F. Entomofauna associada ao algodoeiro anual e mocó precoce em condições de sequeiro: 2. Resultados de 1991. In: CONGRESSO BRASILEIRO DE ENTOMOLOGIA, 14., 1993, Piracicaba, SP. Resumos. Piracicaba: SEB, 1993. p.578.

VIEIRA, F.V.; SANTOS, J.H.R.; LIMA, I.T.; CASTRO, P.E.F. Entomofauna associada ao algodoeiro herbáceo em condições de sequeiro. In: CONGRESSO BRASILEIRO DE ENTOMOLOGIA, 13., \& SIMPÓSIO INTERNACIONAL SOBRE BICUDO DO ALGODOEIRO, 1., ENCONTRO SOBRE "COCHONILHA" DA PALMA FORRAGEIRA, 2., ENCONTRO SOBRE MOSCASDAS-FRUTAS, 3., 1991, Recife, PE. Resumos. Londrina: SEB, 1991 a. p.191.

VIEIRA, F.V.; SANTOS, J.H.R.; LIMA, I.T.; SILVA, F.P. ALMEIDA, E.S. Comportamento de linhagens do algodoeiro herbáceo, Gossypium hirsutum L. r. latifolium Hutch., à ação do "bicudo", Anthonomus grandis BOHEMAN (Coleoptera, Curculionidae). In: CONGRESSO BRASILEIRO DE ENTOMOLOGIA, 13., \& SIMPÓSIO INTERNACIONAL SOBRE BICUDO DO ALGODOEIRO, 1., ENCONTRO SOBRE "COCHONILHA" DA PALMA FORRAGEIRA, 2., ENCONTRO SOBRE MOSCAS-DAS-FRUTAS, 3., 1991, Recife, PE. Resumos. Londrina: SEB, 1991 b. p.538.

VILELA, E.F. Adoção de feromônios no manejo integrado de pragas. Pesquisa Agropecuária Brasileira, Brasília, v.27, p.315318, 1992.

VIVAN, L.M. Impacto do tubo mata bicudo sobre populações de bicudo nos refúgios no período de entressafra no estado do Mato Grosso. In: CONGRESSO BRASILEIRO DE ALGODÃO, 7., 2009, Foz do Iguaçu, PR. Anais. Campina Grande: Embrapa Algodão, 2009. p.658-664.

VOLPE, C.A.; LARA, F.M.; SOARES, J.J. Influência da temperatura e umidade do solo na mortalidade em Anthonomus grandis BOHEMAN, 1843 (Coleoptera, Curculionidae). In: CONGRESSO BRASILEIRO DE ENTOMOLOGIA, 14., 1993,Piracicaba, SP. Resumos. Piracicaba: SEB, 1993. p.38.

WANDERLEY, P.A.; RAMALHO, F.S. Biologia e exigências térmicas de Catolaccus grandis (Burks) (Hymenoptera: Pteromalidae) parasitoide do bicudo-do-algodoeiro. Pesquisa Agropecuária Brasileira, Brasília, v.31, n.4, p.237247, 1996 